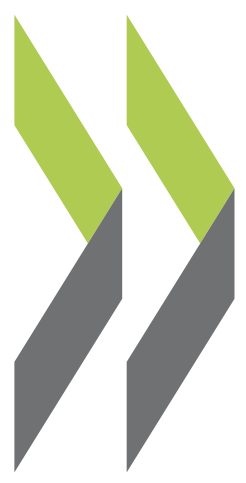

OECD Economics Department Working Papers No. 1041

Improving the Economic Situation of Young People in France
Hervé Boulhol

https://dx.doi.org/10.1787/5k4840dqcbjc-en 


\section{Unclassified}

ECO/WKP(2013)33

Organisation de Coopération et de Développement Économiques

Organisation for Economic Co-operation and Development

05-Apr-2013

ECONOMICS DEPARTMENT

English - Or. English

IMPROVING THE ECONOMIC SITUATION OF YOUNG PEOPLE IN FRANCE

ECONOMICS DEPARTMENT WORKING PAPERS No. 1041

By Hervé Boulhol

All OECD Economics Department Working Papers are available through OECD's Internet website at www.oecd.org/eco/Workingpapers

JT03337647

Complete document available on OLIS in its original format

This document and any map included herein are without prejudice to the status of or sovereignty over any territory, to the delimitation of international frontiers and boundaries and to the name of any territory, city or area. 


\section{ABSTRACT/RÉSUMÉ \\ Improving the economic situation of young people in France}

The economic situation of young people is unsatisfactory. Educational inequalities have been widening for over a decade, due to a sharp decline in the results of the most highly disadvantaged students. The unemployment rate for the 20-24 age bracket has not dropped below 16\% for nearly 30 years. French youth are highly pessimistic about the future and express great distrust of institutions. The social safety net sits uneasily between autonomy and family solidarity and is unfair because young people who are unemployed and have no solid financial backing from their families find themselves in precarious situations. Positive discrimination in education policies should be given a real priority and education spending rationalised to draw more resources to primary schooling. The autonomy of universities should be increased, as should the financial independence of young people. The workings of the labour market, some features of which penalise new entrants, need to be reformed and youth employment services enhanced. This Working Paper relates to the 2013 OECD Economic Review of France (www.oecd.org/eco/surveys/France).

JEL Classification: H52; I21; I24; I25; J20; J30

Keywords: France, youth, education, school failure, primary education, tertiary education, labour market, employment, unemployment, school-to-work transition

$* * * * * * *$

\section{Améliorer la situation économique des jeunes en France}

La situation économique des jeunes n'est pas satisfaisante. Les inégalités scolaires se sont accrues depuis plus d'une décennie, en raison d'une forte baisse des résultats des élèves les plus défavorisés. Le taux de chômage des 20-24 ans n'est pas passé en dessous de $16 \%$ depuis près de 30 ans. Les jeunes français sont très pessimistes quant à l'avenir et expriment une grande méfiance vis-à-vis des institutions. Le filet social hésite entre autonomie et solidarité familiale, et est inéquitable car les jeunes qui sont au chômage et ne disposent pas d'un soutien familial solide financièrement se trouvent dans une situation précaire. La politique d'éducation prioritaire devrait réellement devenir une priorité et les dépenses d'éducation devraient être rationalisées de façon à drainer davantage de ressources vers l'enseignement primaire. Il est souhaitable d'amplifier l'autonomie des universités, de même que l'indépendance financière des jeunes. Le fonctionnement du marché du travail dont certaines caractéristiques pénalisent les nouveaux entrants doit être réformé et les services d'accompagnement des jeunes vers l'emploi améliorés. Ce Document de travail se rapporte à l'Étude économique de l'OCDE de la France 2013 (www.oecd.org/eco/etudes/France).

Classification JEL : H52 ; I21 ; I24 ; I25 ; J20 ; J30

Mots clefs : France, jeunes, éducation, échec scolaire, éducation primaire, enseignement supérieur, marché du travail, emploi, chômage, insertion professionnelle

You can copy, download or print OECD content for your own use, and you can include excerpts from OECD publications, databases and multimedia products in your own documents, presentations, blogs, websites and teaching materials, provided that suitable acknowledgment of OECD as source and copyright owner is given. All requests for commercial use and translation rights should be submitted to rights@oecd.org. 


\section{Table of contents}

Improving the economic situation of young people in France ……................................................. 5

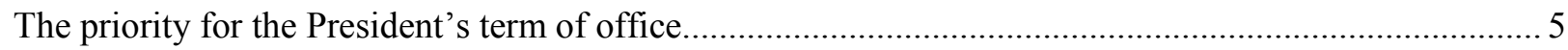

Starting from an already unfavourable position, young people have been hit by the crisis ...................... 7

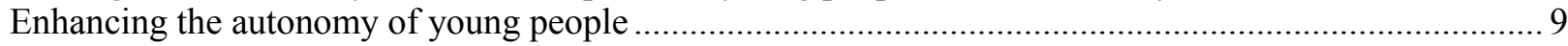

The social networks work well for health care and housing benefits .................................................. 9

A hybrid system that puts substantial emphasis on family benefits.................................................. 9

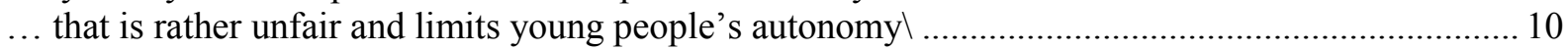

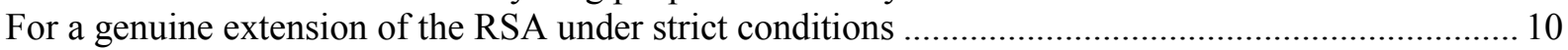

Young people are pessimistic about the future and distrustful of institutions .................................... 11

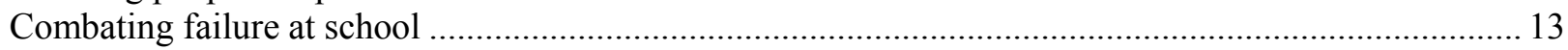

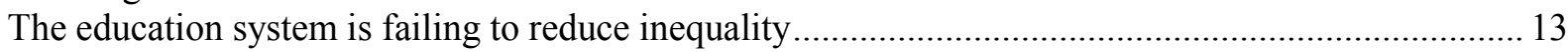

Priority should be given to intervening early in the educational process .......................................... 17

Funding for priority education should be increased considerably ................................................... 19

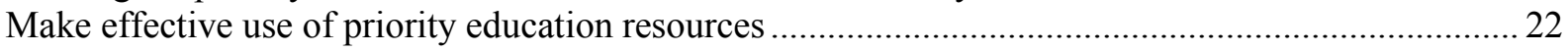

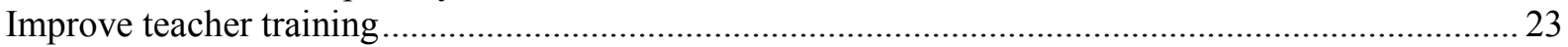

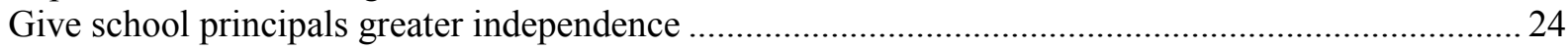

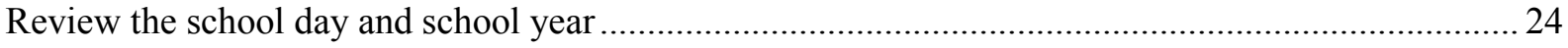

The use of year repetition should be drastically reduced and support for schoolwork improved ......... 25

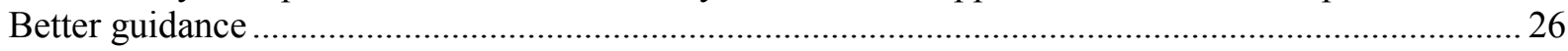

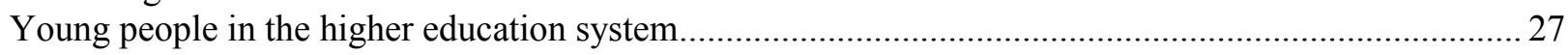

Rebalance public funding in favour of universities and raise enrolment fees ................................... 28

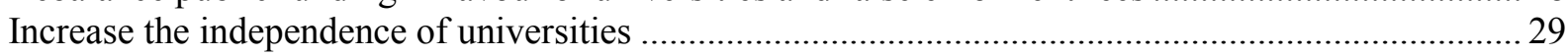

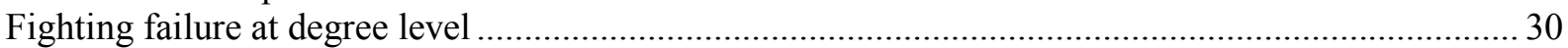

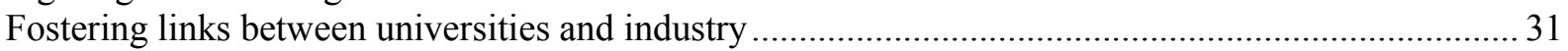

Promoting youth employment and facilitating school-to-work transition............................................ 31

France has had poor performance on the youth labour market for a long time …................................. 31

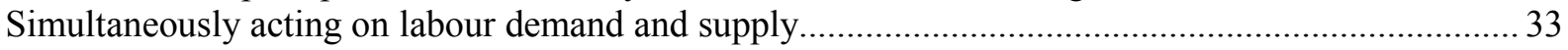

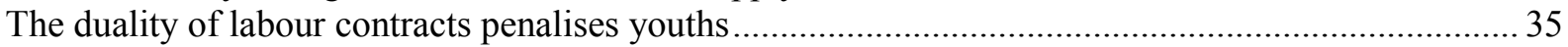

The level of the minimum wage tends to exclude unskilled youths from employment ........................ 38

Subsidised work contracts: promoting a work-study approach for the least skilled................................39

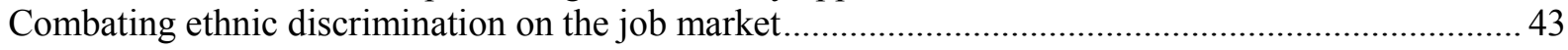

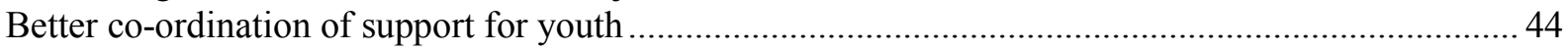

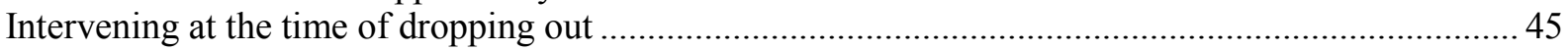

Second-chance schools appear to yield promising results, which should be assessed ......................... 46

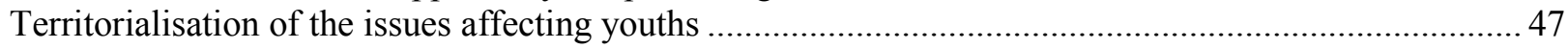

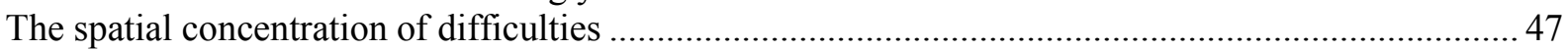

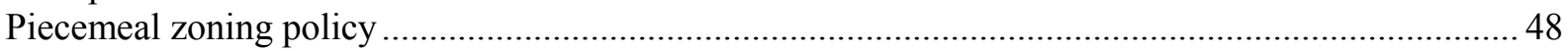

No affirmative action in support of employment in problem neighbourhoods..................................... 48

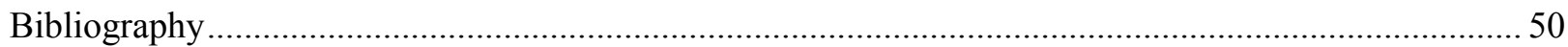

\section{Box}

1. Recommendations to improve the economic situation of young people

\section{Tables}

1. Proficiency trends of pupils in the final year of public primary schools. 


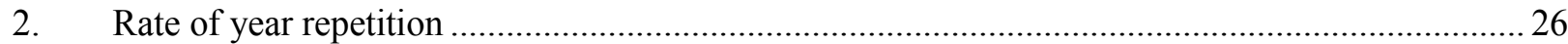

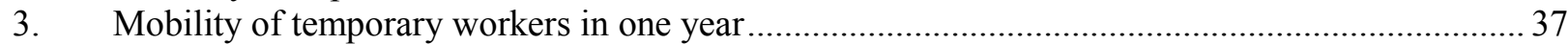

4. Share of children of immigrants not in education among those aged 20-29, around 2007 ........... 43

\section{Figures}

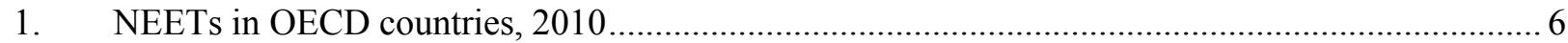

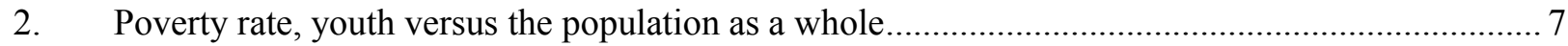

3. Youth unemployment and total unemployment, 15-24 _...................................................... 7

4. Countries which have higher employment rates for youth tend also to be those with higher

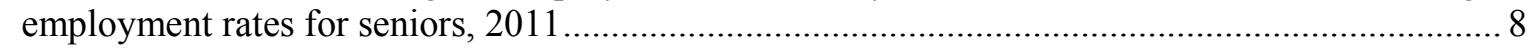

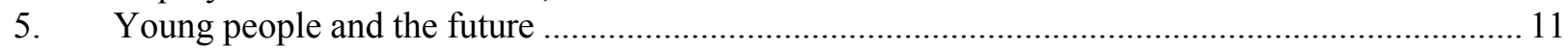

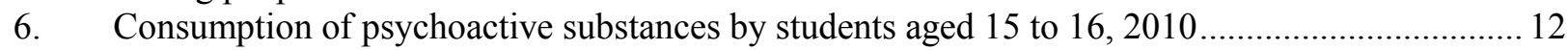

7. Level of youth confidence in institutions, media and multinational corporations......................... 12

8. Population with at least an upper-secondary school education by age group, $2010 \ldots \ldots \ldots \ldots \ldots \ldots . . . . .13$

9. A substantial number of pupils do not master basic skills......................................................... 14

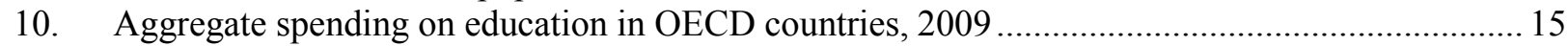

11. Outcomes are not related to education spending for the more affluent OECD countries............... 15

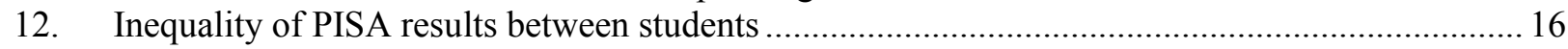

13. PISA scores of the poorest-performing students (10th percentile), 2009................................. 16

14. Relationship between student performance and socio-economic background .............................. 17

15. Rates of return on equal investments in human capital, by age of target group ............................ 18

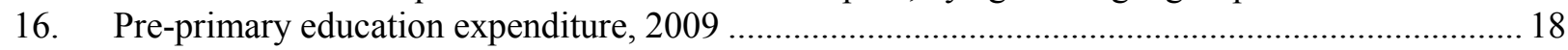

17. Ratio of annual spending per primary school pupil to that for upper-secondary education,

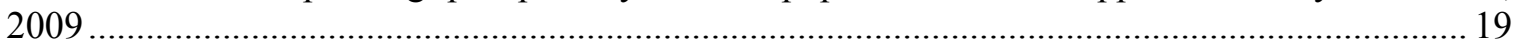

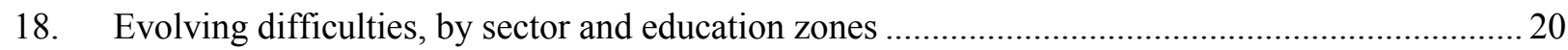

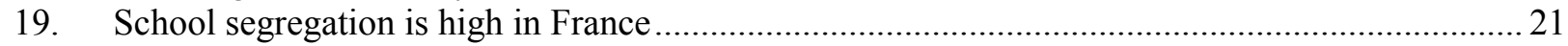

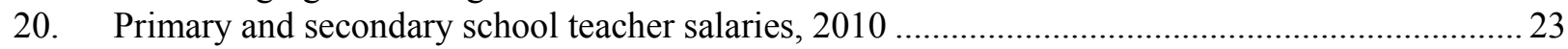

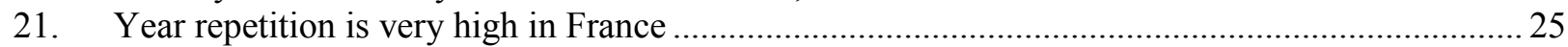

22. Unemployment rate and real salaries from one to four years after initial training .......................27

23. Spending per student for the various higher education sectors, 2009 ........................................ 28

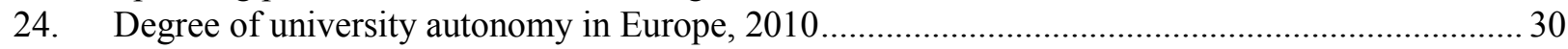

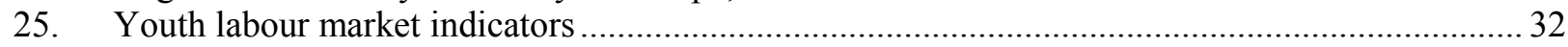

26. Explaining the gap between the unemployment rate in France versus other OECD

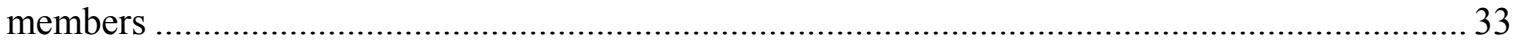

27. Employment rate by age bracket, ranked classification ........................................................ 34

28. The difficulties confronting youths reflect a broader problem with the labour market.................. 34

29. Sensitivity of the youth unemployment rate to economic fluctuations, $15-24$ years..................... 35

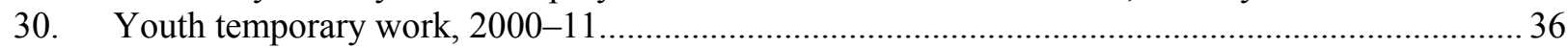

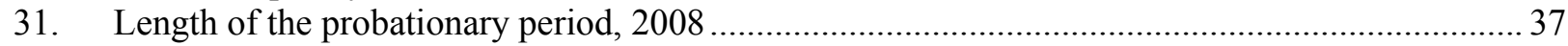

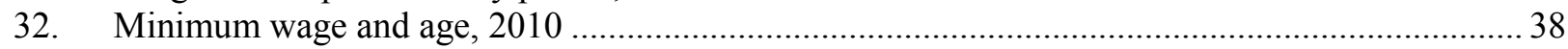

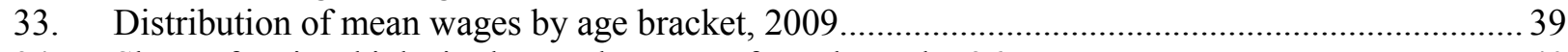

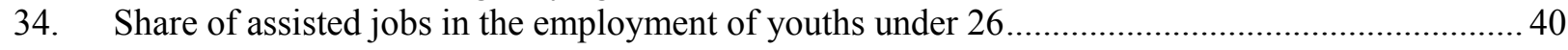

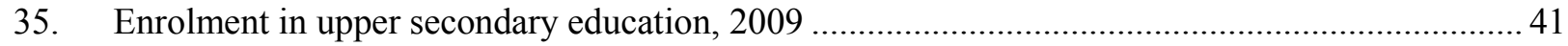

36. Labour-management relations do not seem to be of good quality................................................ 42

37. Number of apprentices at year end by level of diploma ............................................................. 42

38. Gap between unemployment rates of children of immigrants and native-born aged 20-29, 2007.

The statistical data for Israel are supplied by and under the responsibility of the relevant Israeli authorities. The use of such data by the OECD is without prejudice to the status of the Golan Heights, East Jerusalem and Israeli settlements in the West Bank under the terms of international law. 
ECO/WKP(2013)33

\title{
Improving the economic situation of young people in France
}

\author{
By \\ Hervé Boulhol $^{1}$
}

\section{The priority for the President's term of office}

Youth is the priority of the French President. Educational inequalities have been widening for over a decade, with an absolute decline in outcomes for the most disadvantaged students. The unemployment rate for the 20 to 24 age bracket has not dipped below $16 \%$ for nearly 30 years. At year-end 2010, roughly 1.9 million young people aged between 15 and 29, i.e. one in six, were neither in employment nor in education or training (NEET): 300000 aged 15 to 19 (7\% of that age bracket), 800000 aged 20 to 24 (21\%) and 800000 aged 25 to 29 (21\%) (Figure 1). Their paths to achieving stable employment are long and difficult. These characteristics place France in the lower half of OECD countries in terms of performance in this area.

Between 2000 and 2010, the relative poverty rate of those aged 18 to 29 increased from 16 to $18 \%$ using a threshold of $60 \%$ of median income. At the same time, the corresponding proportion for the population as a whole was virtually stable between $13 \frac{1}{2}$ and $14 \%$, but it has increased since the beginning of the crisis in 2008. As compared to other OECD countries, France has nonetheless performed well in combating poverty for the population as a whole and for young people as well, albeit to a lesser extent (Pisu, 2012 and Figure 2).

The geographic concentration of situations of extreme poverty in which young people are overrepresented creates a climate of tensions. The 2005 violence in certain suburban housing projects left a lasting impression and was widely publicised. According to Mauger (2007), by burning schools and libraries, young people were saying symbolically that public schools have not only treated them as they should have, but that the schools have even amplified the inequalities and injustices afflicting them. The failure rate is so high that the institution would no longer be perceived as a help, but as an instrument of humiliation and exclusion (Mauger, 2007). And yet young people constitute a diverse population that cannot be reduced merely to the problem of so-called "sensitive urban zones" (ZUS) (in fact only one in seven young NEETs lives in a ZUS). More generally, youth unemployment and insecurity are powerful

1. Senior Economist, OECD Economics Department; e-mail: herve.boulhol@oecd.org. This paper has been written for the OECD Economic Survey of France published in March 2013 under the authority of the Economic and Development Review Committee. The author is grateful to Patrizio Sicari for excellent statistical support. The author wishes to thank numerous colleagues for the quality of their comments, including Peter Jarrett but also Stéphane Carcillo, Éric Charbonnier, Andrew Dean, Robert Ford, David Grubb, Anne Sonnet and Richard Yelland, as well as academic researchers and numerous experts working for the French government for their valuable suggestions. Special thanks are also due to Mee-Lan Frank and Maartje Michelson for technical preparation. 
determinants of delinquency (Fougère et al., 2011). Youth issues involve the education system as a whole, labour-market integration and, beyond that, the prerequisites for attaining autonomy, and youth policies should strive to facilitate the transition from childhood to adulthood.

Figure 1. NEETs in OECD countries, ${ }^{1} 2010$

As a percentage of the population by age bracket

$\%$
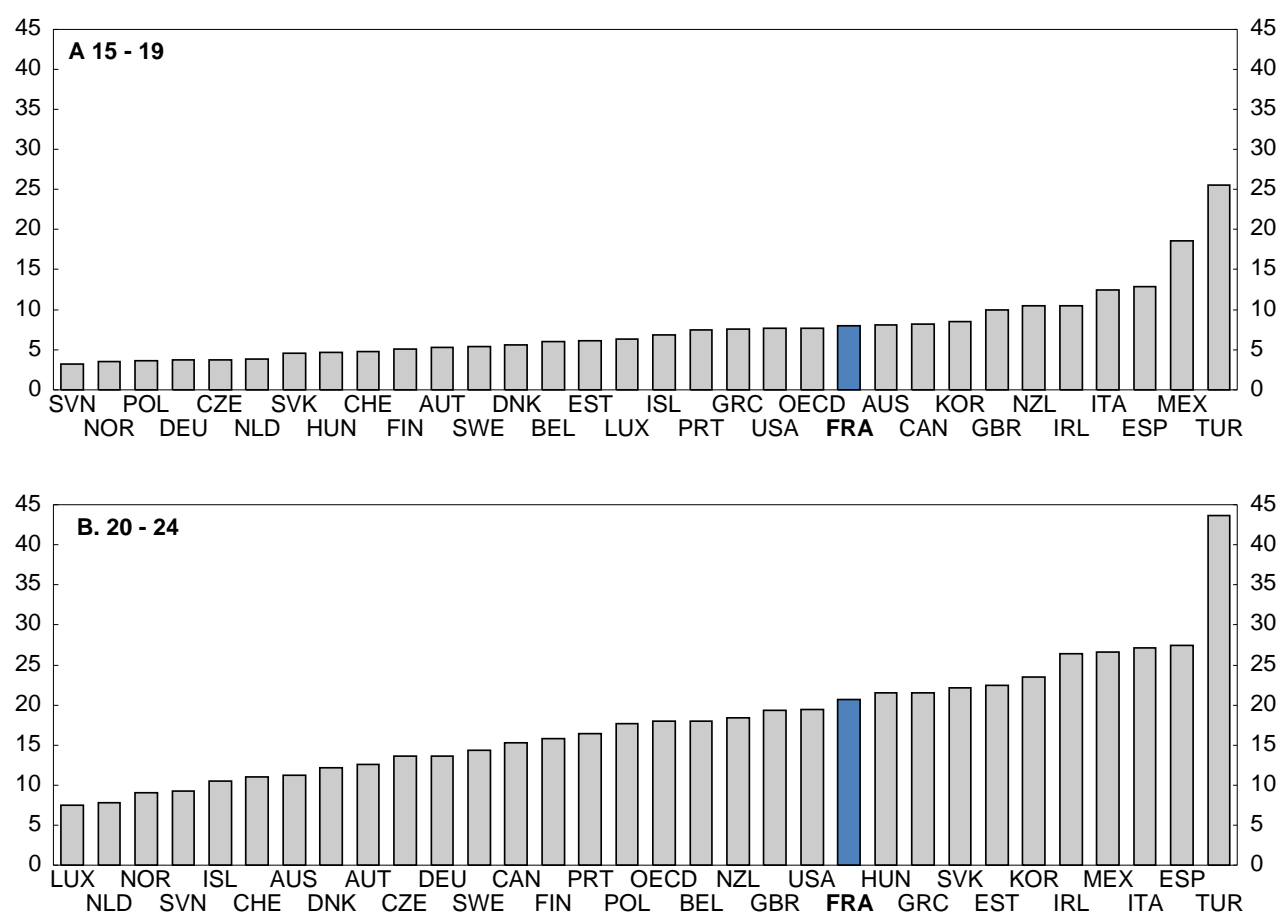

$\%$

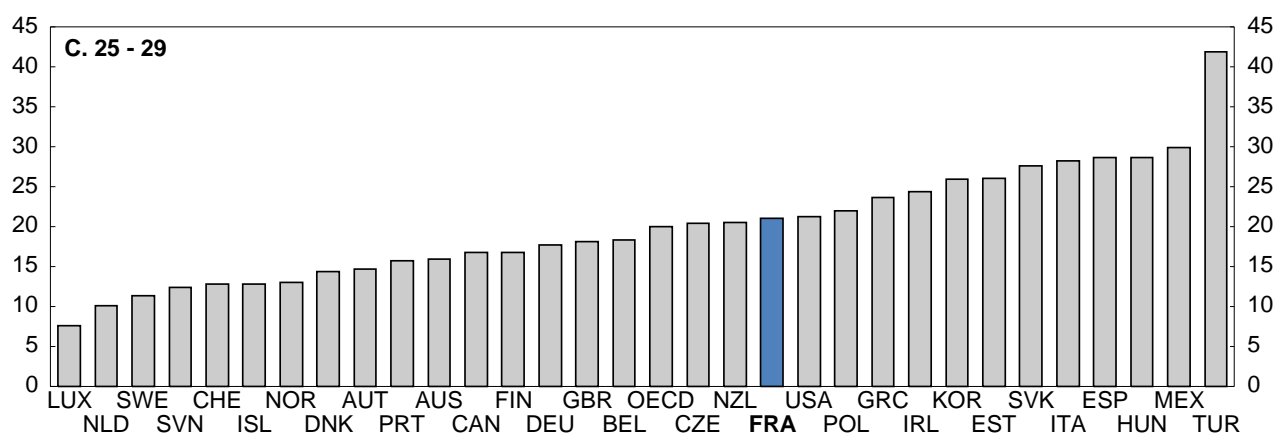

1. NEETs are those who are not in employment, nor in education or training.

Source: OECD, 2012 Education database. 
Figure 2. Poverty rate, youth versus the population as a whole End of the 2000s ${ }^{1}$

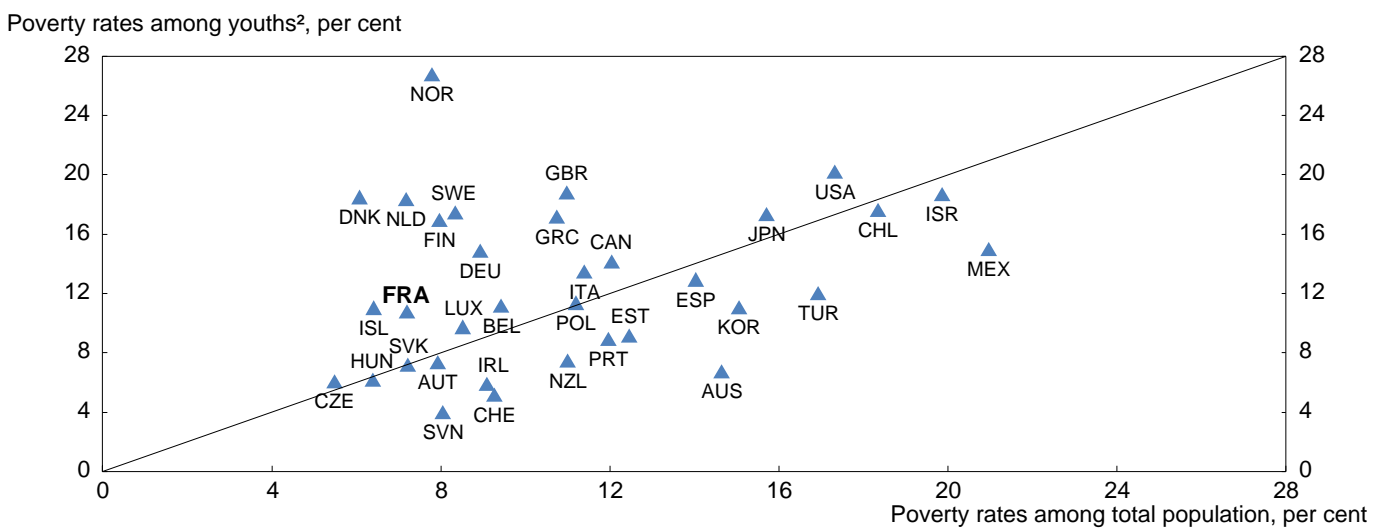

1. The poverty rate is measured by the proportion of individuals whose equivalised household disposable income is lower than $50 \%$ of the median income for the population as a whole.

2. Aged 18 to 25 .

Source: OECD database on income distribution and poverty.

\section{Starting from an already unfavourable position, young people have been hit by the crisis}

As in most OECD countries, young people have been hit especially hard by the worsening employment situation since 2008. Declining aggregate demand weighs more heavily on jobseekers and those whose employment contracts provide less protection. While $9 \%$ of young people aged 15 to 24 are unemployed, their unemployment rate (relative those in the labour force) reached $24 \%$ at the end of 2012 (Figure 3). And among these young people, in France as elsewhere, it is those with the least education that are paying the highest price for the protracted crisis (OECD, 2011a). The situation is all the more worrisome insofar as young people who have the misfortune of entering the labour market at a time of economic crisis may bear the resulting scars for a long time (Scarpetta et al., 2010a). However, according to the estimates of Gaini et al. (2012) using French data between 1982 and 2009, the employment and wage differentials between "lucky" and "unlucky" cohorts tend to vanish within four years.

Figure 3. Youth unemployment and total unemployment, 15-24
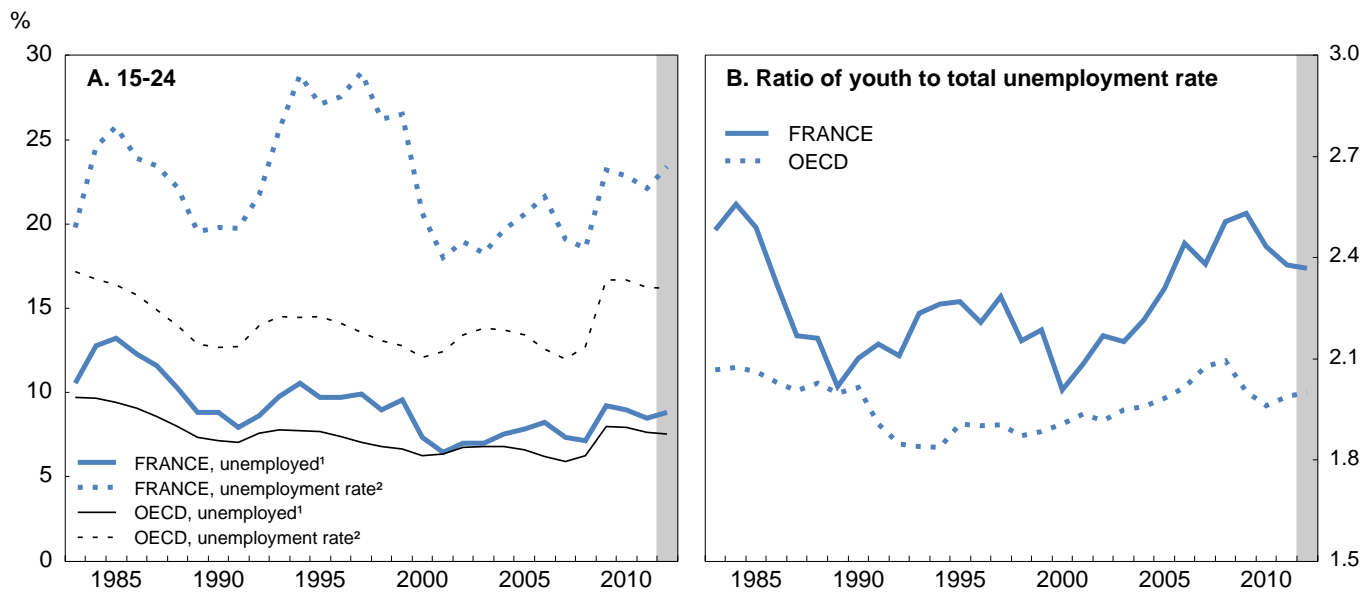

1. As a percentage of the population aged 15 to 24 years.

2. As a percentage of the active population aged 15 to 24 years.

Source: OECD, 2012 Labour Force Statistics database. 
OECD (2011a) has highlighted the urgency of providing suitable support to those young people running the greatest risk of losing contact with the job market. This is especially true in France, where the young can slip through the cracks of a social protection system that otherwise provides an effective safety net. Insofar as youth unemployment is for the most part structural ${ }^{2}$, this state of emergency is a permanent fixture. To improve preparations for the end of the crisis, efforts to train NEETs should be stepped up (OECD, 2011a). For young unskilled people the emphasis should be on apprenticeship contracts that combine job-related training and initial occupational experience, since international initiatives have shown that for this age group the use of training programmes alone yields limited results.

In France, the poor state of public finances has precluded an optimal countercyclical response. Nevertheless, to limit the economic slowdown's impact on young people's situation, between April 2009 and December 2010 the government instituted an emergency youth employment plan, including work-study, incentives to convert internships to permanent contracts and a relaunching of subsidised contracts. These measures contributed to the drop in youth unemployment between late 2009 and mid-2011. At least the errors of the past were avoided: early-retirement schemes were not used to "make room for the young" (OECD, 2011a), as experience has indeed shown clearly that there is no substitution between the employment of young people and seniors (Gruber et al., 2009) (Figure 4). Faced with the persistent stagnation of economic activity since year-end 2011, in September 2012 the new government launched new subsidised contracts - "jobs for the future" and began in early 2013 to introduce "generational contracts", the goal of which is both to encourage the hiring of young people on permanent contracts and to keep seniors at work (see below).

Figure 4. Countries which have higher employment rates for youth tend also to be those with higher employment rates for seniors, 2011

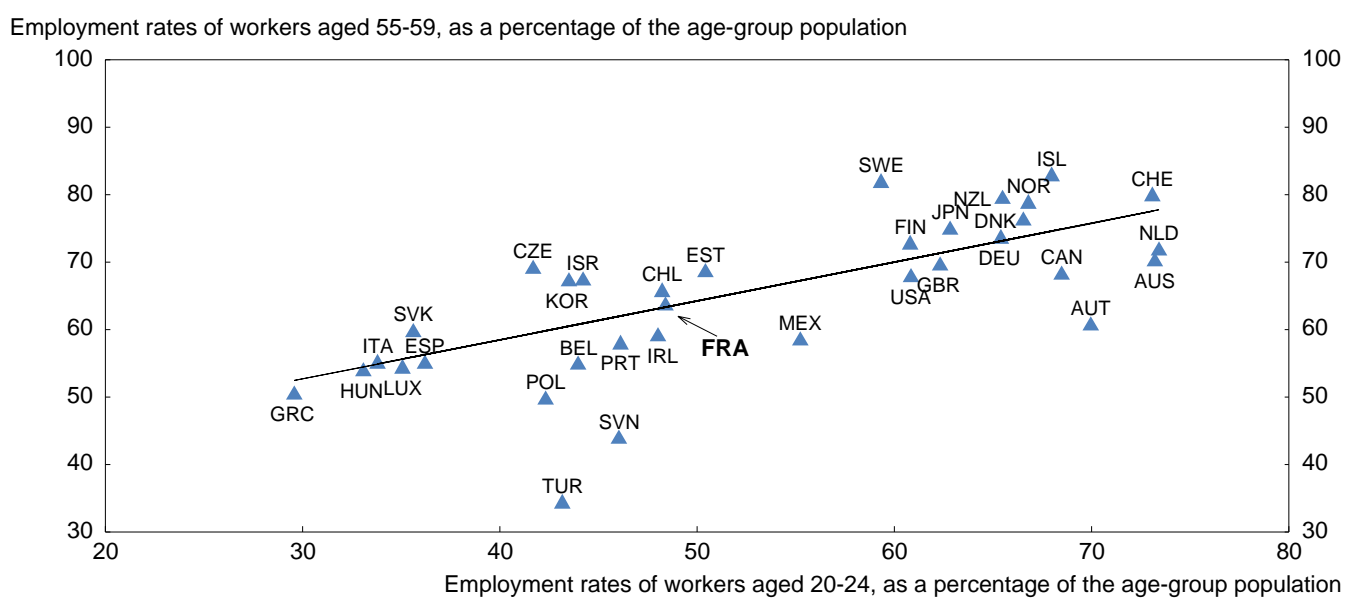

Source: OECD, 2012 Labour Force Statistics database.

2. According to OECD estimates, the structural unemployment (NAIRU) for the entire labour force is about $90 \%$ of the total unemployment rate and the ratio of youth to total unemployment rate has been roughly stable since the mid-2000s. 


\section{Enhancing the autonomy of young people}

\section{The social networks work well for health care and housing benefits}

Having lower income, ${ }^{3}$ young people may encounter difficulties accessing such essential goods and services as health care and housing. Nevertheless, social security cover for basic health care is universal in France, and complementary insurance schemes (including complementary universal coverage, which is provided on a means-tested basis) cover $94 \%$ of the population. Young people and those over 80 are admittedly the least well covered, yet still at a rate of $90 \%$, which is the average that had prevailed for the population as a whole at the beginning of the 2000s. Young people can also get relatively generous personal housing subsidies. These benefits amount to approximately EUR 5 billion ( $0.25 \%$ of GDP) for those 16 to 25, EUR 1.5 billion of which for students, and are split evenly between aid to families (for "dependent children") and benefits paid to young people directly (Clergeau, 2009).

Despite these aid schemes, young people are bearing the full brunt of higher housing costs. The shortage of student housing has recently attracted the attention of policymakers. ${ }^{4}$ In April 2011 the authorities committed themselves to the extremely bold objective of doubling the number of student dwellings to 680000 by 2020 (for his part, however, President Hollande foresees the construction of 40000 student dwellings over five years (Floc'h, 2012)). Nearly half of those between 18 and 30 live with their parents, and the proportion of social housing dwellers under 30 dipped from $12.5 \%$ to $10 \%$ between 2003 and 2009 as a result of population ageing (OPH, 2011). The low share of young adults living in social housing can also be explained in part by the relative shortage of small dwellings, problems related to poor targeting in social housing assignment and low residential mobility in this sector - inefficiencies that were analysed in the previous Survey (OECD, 2011b).

\section{A hybrid system that puts substantial emphasis on family benefits...}

In addition to public expenditure on education, labour market integration (see below) and individual housing aid, government spending on youth essentially comprises: family benefits paid to parents in respect of their adult dependent children (EUR 2.3 billion per year); personal income tax relief, thanks to the "family quotient" (see Égert, 2013), deductibility of higher-education expenses and of child support payments (EUR 2.5 billion); means-tested higher-education scholarships paid directly to students (EUR 1.8 billion); ${ }^{5}$ and coverage of the deficit of the students' health insurance scheme and subsidies to regional student welfare offices (EUR 1 billion) (Commission sur la politique de la jeunesse, 2009; $\mathrm{HCF}, 2010)$. In the aggregate, these expenditures amount to approximately $0.4 \%$ of GDP.

Thus, most of the measures benefiting youth involve housing aid or family benefits, the system for which is designed around the notion of "dependent children", conferring entitlement to financial compensation and tax breaks). Roughly $30 \%$ of young people aged 16 to 25 are classified as dependent children for tax purposes. Age limits for inclusion in the family tax unit vary from one benefit to another; for example, the maximum is 18 for the yearly back-to-school allowance, 20 for family allowances (which are not means-tested), 21 for the family income supplement (for families with at least three dependent

3. Since the mid-1990s, average income for the 18 to 25 year-old age bracket has been a fairly constant $14 \%$ below that for all ages combined.

4. Between 35 and $40 \%$ of the 2.2 million students live with their families. In 2012, the stock of dedicated student housing consisted of 340000 rooms: approximately 160000 places in residences operated by regional student welfare centres (CROUS), whereas 350000 students would like to live there (Floc'h, 2012); 40000 non-CROUS social housing units; 40000 places in campus housing and residences operated by the Grandes Écoles; and 100000 places in private residences

5. 540000 students hold scholarships. A fifth of them receive the maximum amount, i.e. $€ 4300$ per year. 
children under the age of 21 , which is means-tested) and 25 for the inclusion of students. There are, in fact, over 100 age limits covering young people in employment, social benefits and tax schemes (Commission sur la politique de la jeunesse, 2009, Annex 5). There are intermediate situations whereby young adults can be included in their parents' households for tax purposes, while still receiving personal allowances (housing aid, certain social minimum income allowances, etc.) in their own right. As a result, the actions of the family branch of Social Security with regard to young adults lack clarity in its objectives and in the effectiveness of its various schemes (Clergeau, 2009). Between autonomy and family solidarity, youth policy wavers haphazardly.

\section{... that is rather unfair and limits young people's autonomy|}

Childless young adults are virtually excluded from the main social welfare scheme - the "active solidarity income allowance" (revenu de solidarité active, RSA), for which they are eligible only from age $25 .^{6}$ This unfavourable treatment is rather unique in the OECD area, since welfare benefits are open to the young as from age 18 in all countries except Spain, France and Luxembourg (OECD, 2009). Compounding the disadvantage, despite entitlement after four months of contributions (during the last 28 months), is an inherently shorter duration of unemployment benefits for people with little average work experience. In some ten OECD countries, 20 year-old jobseekers who have never worked are entitled to benefits, provided, however, that they meet certain conditions, including compliance with reciprocal commitments (OECD, 2009, Box 6.3). The strategy for getting young dropouts into work should be centred on the acquisition of a skill, as in Denmark - a pioneer in this area. Since 1996, the unemployment benefit for Danish 18 to 24 year-olds without an upper-secondary school diploma has been cut in half after six months of unemployment, to a level equivalent to that of a student benefit, and recipients are required to return to initial training, in most cases under an apprenticeship programme. In France, their overall situation puts young people who are unemployed and without solid family financial support in a shaky situation.

\section{For a genuine extension of the RSA under strict conditions}

A genuine extension of the means-tested RSA to young adults would reduce the intensity of poverty and, if well designed, would facilitate labour-market integration, which takes longer than it did in the past and is longer than in many neighbouring countries. To limit the cost and optimise effectiveness, it should be increasing with age and reserved for NEETs alone, while students would continue to be supported by the scholarship system (subject to parents' means-testing) and by loans with repayments conditional on future income, which ought to be developed (see below). The key to the scheme's success and a sine qua non condition would be to root it firmly in compliance with reciprocal obligations facilitating integration into work. These mutual obligations would drastically reduce both the negative impact of the allowance on the supply of labour and the opportunity cost of continuing one's studies. The allowance could even enhance the effectiveness of job placement support, since current schemes generally lack effective incentives. Supporting the allowance by effective activation measures therefore constitutes a prerequisite

6. Young people with family responsibilities (at least one child already born or on the way) or living with a partner over the age of 25 are eligible for the RSA. Since September 2010, young people with no family responsibilities but having worked the equivalent of two years full-time over the three years preceding their applications have also been also eligible (for the "Youth RSA"). Young people, if their resources are sufficiently low, may be included in their parents' tax households until age 25. Secondary- or highereducation students and interns are ineligible for the RSA whether or not they are under 25. At year-end 2011, 140000 young persons under 25 were receiving the RSA as young persons with family responsibilities, and fewer than 10000 were getting the "Youth RSA". The proportion of young persons under 25 amongst aggregate RSA recipients has been more or less stable since June 2009, at around 7\%, as compared to approximately $20 \%$ for the 25 to 29 age bracket. 
for its successful implementation. This is an area in which France must do better (Égert, 2013), insofar as its performance falls far short of the good practices developed in such countries as Australia, Denmark, the Netherlands and the United Kingdom (OECD, 2009). As part of the fight against poverty (see Box 3 of the Assessment and Recommendations section), the government intends to institute a "youth guarantee" conditional on participation in programmes for getting them into work, the amount of which would be similar to the RSA and reserved for highly vulnerable NEETs. The scheme would ultimately target 100000 young persons aged 18 to 24 , or only about $10 \%$ of the NEETs in that age cohort.

If, for example, the allowance were to rise gradually from $50 \%$ of the full RSA (which is EUR 475 per month for a childless single person) at age 18 , to $100 \%$ at age 25 (or 23), the annual cost of the measure would be close to EUR 4 billion (or EUR 4.3 billion) and could be financed entirely by eliminating the advantages that result from the inclusion of young adult children in the family tax unit (EUR 4.8 billion, see above). Ideally, such a reform would be accompanied by complementary measures, the rationale for which is set out in this paper. For example, the RSA phase-in rate, as a function of age, could also be used to index the minimum wage to age (see below).

\section{Young people are pessimistic about the future and distrustful of institutions}

French youth are pessimistic about their futures and that of society (Figure 5). According to Galland (2009), this pessimism could stem in part from difficulties finding work, which in turn result from the protection of workers on permanent contracts and a limited social safety net for young people, but also a deep mistrust of institutions and elites and the frequency with which students are rated during their schooling. On average, French youth consume significantly more alcohol, tobacco, cannabis and other drugs than do youth elsewhere (Figure 6). By international standards, they also have an especially low degree of trust in politicians (and in the media and multinational enterprises as well) (Figure 7).

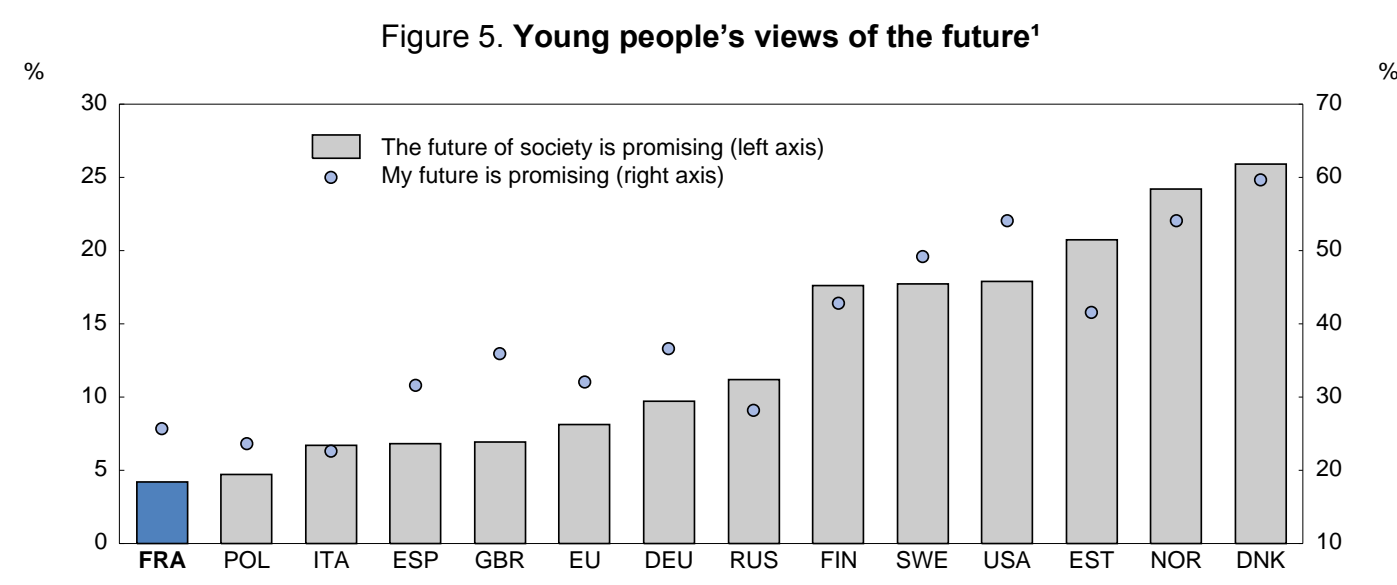

1. Percentage agreeing with each statement.

Source: Les jeunesses face à leur avenir: une enquête internationale; Fondation pour l'Innovation Politique, 2008. 
Figure 6. Consumption of psychoactive substances by students aged 15 to 16,2010

As a percentage of students aged 15 to 16

$\%$
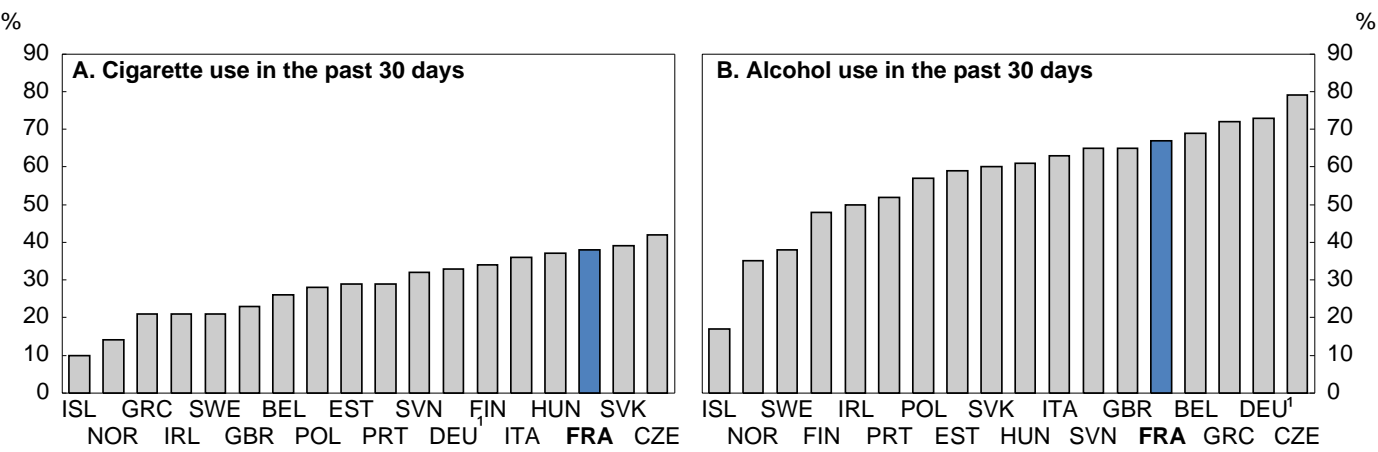

$\%$
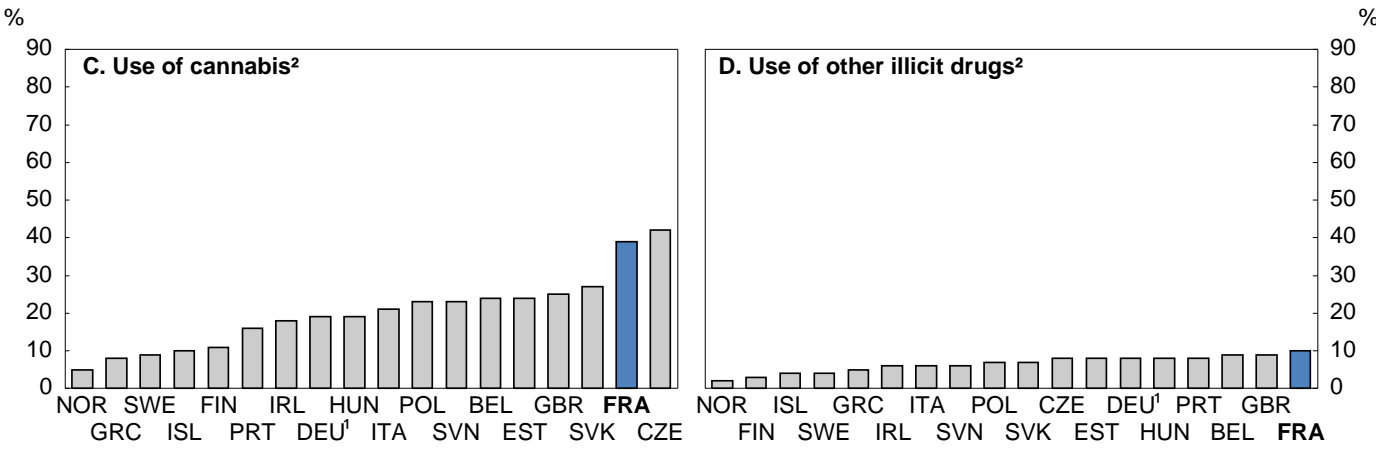

1. Seven Länder only.

2. At least once in their lives.

Source: The European Monitoring Centre for Drugs and Drug Addiction (EMCDDA), 2011 ESPAD survey.

Figure 7. Level of youth confidence in institutions, media and multinational corporations ${ }^{1}$ Young people aged 16 to 29

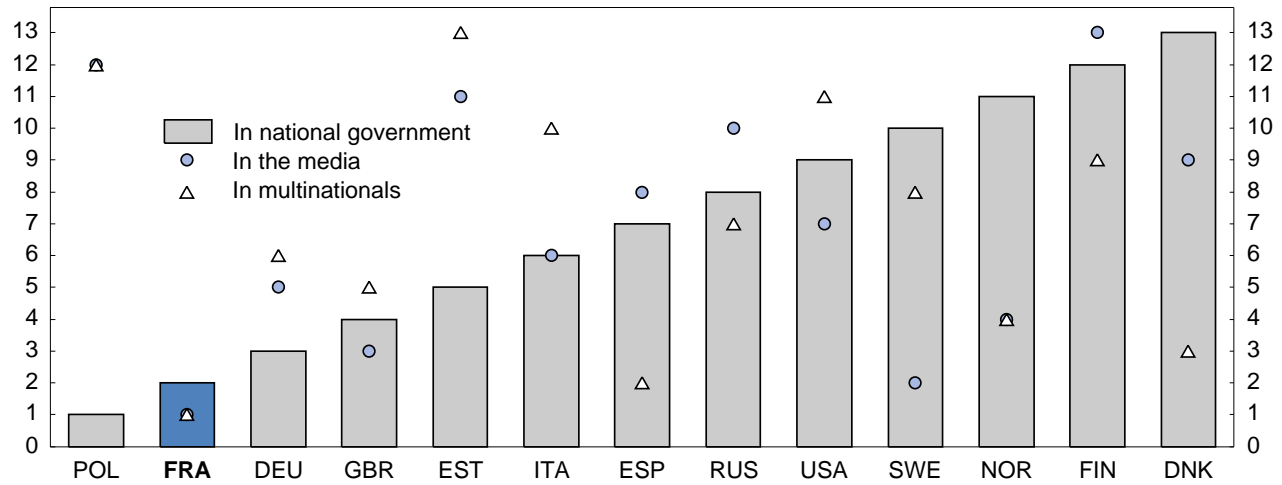

1. Countries are ranked by percentage of those having confidence in the institution in question; thus young Poles are the least likely to express confidence in their country's government, whereas young Danes rank first.

Source: Fondation pour l'Innovation Politique (2008), Les jeunesses face à leur avenir, une enquête internationale.

In terms of political economy, young people might suffer from an insider-outsider power struggle unfavourable to them: a high minimum wage, which tends to exclude them from employment; strong protection for permanent contracts, which complicates their finding work; and exclusion from the RSA, which impoverishes them Cahuc et al., 2011). 


\section{Combating failure at school}

The quality of education is a key determinant of a country's economic performance and of integration into society and the autonomy of all young people. When it works, the education system can be a powerful force for lessening inequalities. There is scope for improvement in France at all levels, but efforts should focus mainly on primary schools and universities.

\section{The education system is failing to reduce inequality}

The general level of education improved spectacularly until the mid-1990s, allowing France to bridge most of its gap with the most economically advanced countries (Figure 8). After growing very rapidly between 1985 and 1995, and then more moderately, the share of the 25-34 year-old age cohort who receive an upper-secondary school qualification is $84 \%$, slightly above the OECD average. The share of those getting a baccalauréat increased significantly, from $20 \%$ in 1970 to $66 \%$ of the age cohort in 2012, thanks in part to the creation of a vocational version in 1987.

Nevertheless, the deterioration of certain indicators is worrisome and, if nothing is done to remedy the situation, would seem to portend severe economic and social difficulties in the longer term. First, surveys conducted at the conclusion of primary school at a roughly ten-year interval show that pupils' average proficiency has dropped (Table 1). Second, the proportion of 15 year-old students whose performance is strictly below Level 2 proficiency (on a scale of 0 to 6 ) rose significantly, from $15 \%$ in 2000 to $20 \%$ in 2009 (Figure 9), whereas that share remained stable on average across the OECD area, placing France in the low-to-average range. Third, after a low point of $15 \%$ in $1998,20 \%$ of students (or about 150000 young people each year) drop out of school without an upper-secondary school diploma, placing them at a handicap in finding work. Fourth, the enrolment rate at age 18 , which had risen sharply to $85 \%$ in 1995, has slipped back to $80 \%$ since 2005. Trends in the latter two indicators put France near the OECD average.

Figure 8. Population with at least an upper-secondary school education by age group, 2010

As a percentage of the population

$\%$

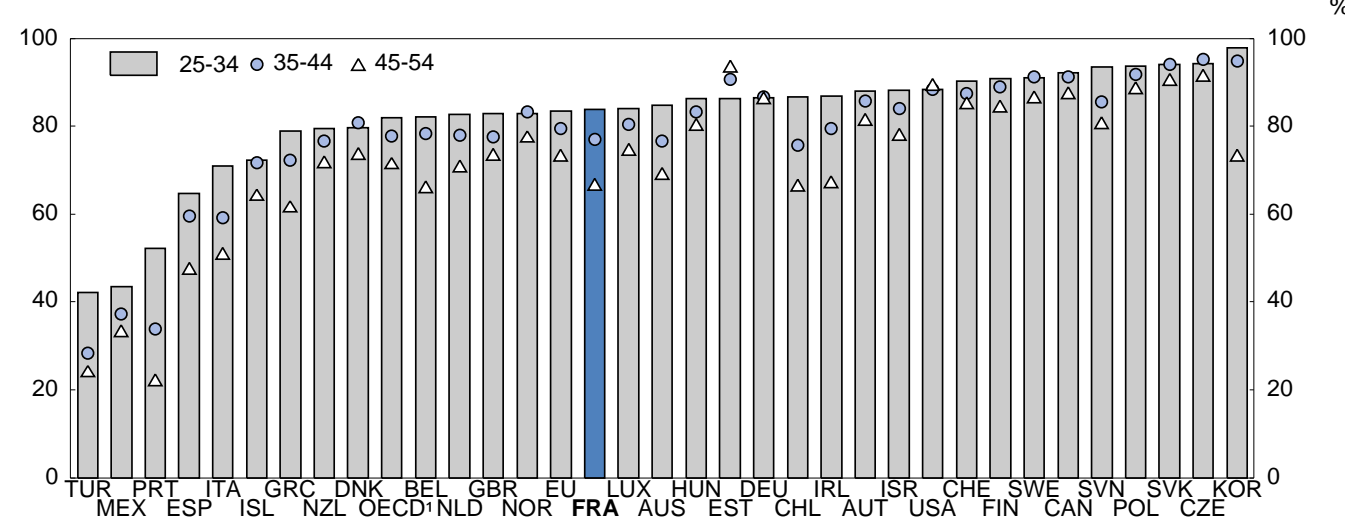

1. Excluding Japan.

Source: OECD, Education at a Glance 2012 database. 
Table 1. Proficiency trends of pupils in the final year of public primary schools ${ }^{1}$

Excluding French overseas departments and territories

\begin{tabular}{|c|c|c|c|}
\hline & 1987 & 1997 & 2007 \\
\hline & \multicolumn{3}{|c|}{ Reading } \\
\hline Average & 0 & -0.03 & -0.37 \\
\hline Standard deviation & 1 & 1.02 & 1.22 \\
\hline$\leq 1^{\text {st }}$ decile 1987 & $10 \%$ & $11 \%$ & $21 \%$ \\
\hline$\leq$ Median 1987 & $50 \%$ & $51 \%$ & $61 \%$ \\
\hline \multirow[t]{2}{*}{$\geq 9^{\text {th }}$ decile 1987} & $10 \%$ & $10 \%$ & $8 \%$ \\
\hline & \multicolumn{3}{|c|}{ Mathematics } \\
\hline Average & 0 & -0.65 & -0.84 \\
\hline Standard deviation & 1 & 1.19 & 1.15 \\
\hline$\leq 1^{\text {st }}$ decile 1987 & $10 \%$ & $28 \%$ & $32 \%$ \\
\hline s Median 1987 & $50 \%$ & $75 \%$ & $80 \%$ \\
\hline \multirow[t]{2}{*}{$\geq 9^{\text {th }}$ decile 1987} & $10 \%$ & $8 \%$ & $4 \%$ \\
\hline & \multicolumn{3}{|c|}{ Writing $^{2}$} \\
\hline Number of errors & 10.7 & - & 14.7 \\
\hline$\leq 2$ errors & $13 \%$ & - & $6 \%$ \\
\hline$\geq 25$ errors & $6 \%$ & - & $12 \%$ \\
\hline Lexical errors & 2.1 & - & 2.6 \\
\hline Grammatical errors & 7.1 & - & 10.8 \\
\hline Punctuation errors & 1.1 & - & 0.9 \\
\hline
\end{tabular}

1. The reference here for comparisons is 1987: scores averaged 0, and the standard deviation was 1 in 1987. A negative average value indicates a value lower than the average score in 1987.

2. Based on the same dictation exercise over all surveys.

Source: Ministry of National Education (2009), L'État de l'école.

Figure 9. A substantial number of pupils do not master basic reading skills

Percentage of 15 year-old students with proficiency at or below Level 2 on the PISA reading proficiency scale

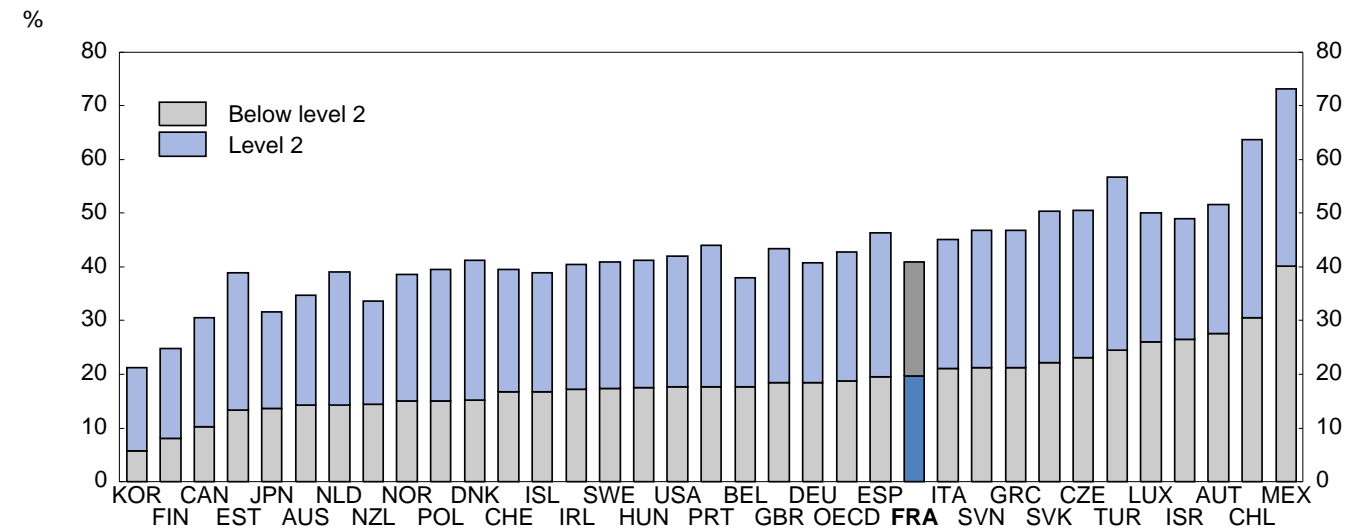

Source: OECD (2010), PISA 2009 Results: Overcoming Social Background; Equity in Learning Opportunities and Outcomes.

Since the late 1990s, France has each year allocated approximately 6\% of GDP to education, expenditure per student representing roughly a quarter of per capita GDP and the number of students a quarter of the total population. These figures put France near the OECD average (Figure 10). The OECD's PISA tests have revealed that the better performance achieved by countries such as Finland, Canada, Japan, 
the Netherlands and Australia in particular could not be explained by greater expenditure (Figure 11). This would suggest that there is substantial scope to increase the effectiveness of the French education system, even without increasing its budget.

Figure 10. Aggregate spending on education in OECD countries, 2009

As a percentage of GDP

$\%$

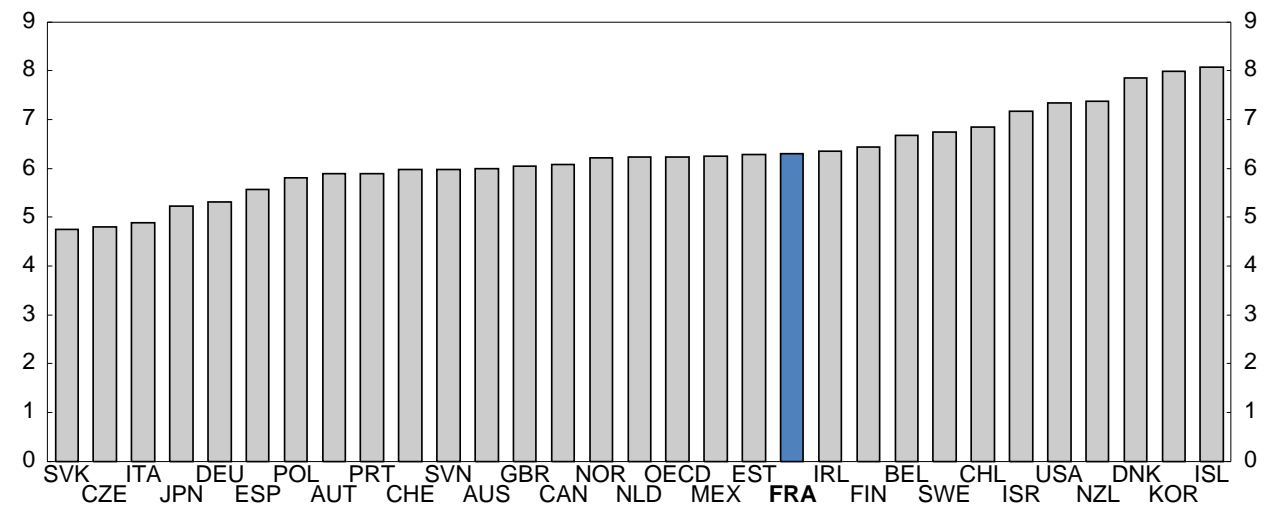

Source: OECD, Education at a Glance 2012.

Figure 11. Outcomes are not related to education spending for the more affluent OECD countries 2009

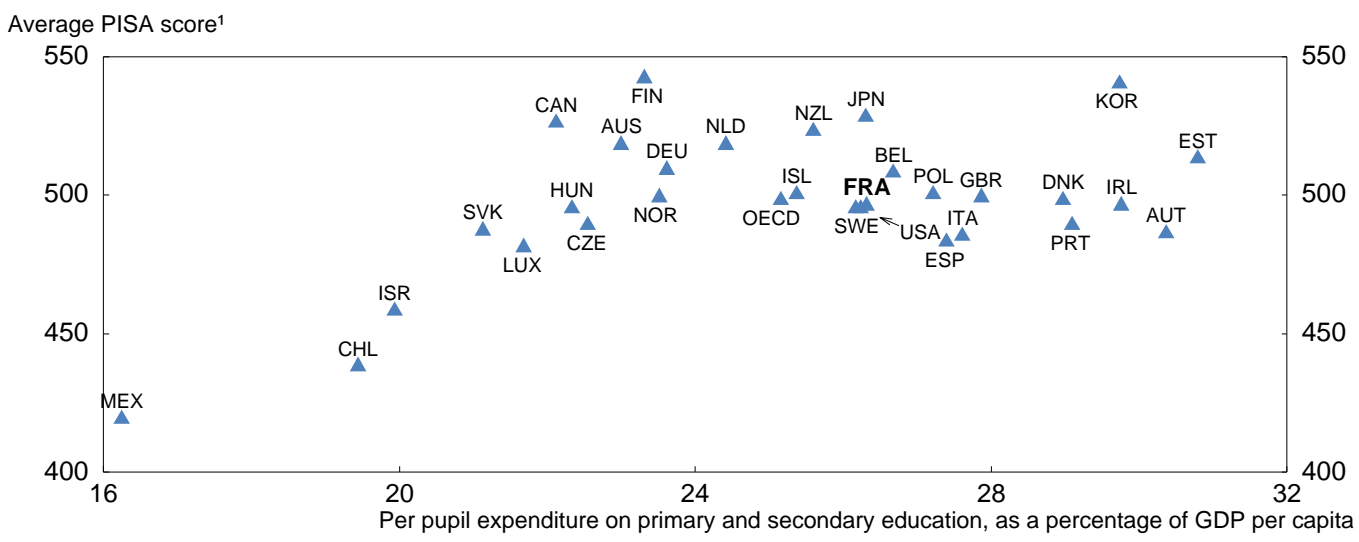

1. Average of PISA scores on the reading, mathematics and science scales.

Source: OECD, Education at a Glance 2012 and 2009 PISA Results databases.

Above all, according to PISA results, the dispersion in terms of the level of education of 15 year-old students is reaching a disturbing level. The ratio of scores obtained by the top $5 \%$ of students to those of the worst 5\% performers exceeds 2, with Luxembourg alone showing higher levels of inequality (Figure 12, Panel A). Since 2000, France (along with Japan, which started from a moderate level of inequality) has seen inequality increase most sharply; this situation is made even worse because it stems from a pronounced decline in the results of the worst performing students (Figure 12, Panel B). As a result, their level is among the lowest in any OECD country (Figure 13). When the heterogeneity of the population is taken into account, France's cumulative gap with the best performing countries shrinks by 
about half. Nevertheless, the bulk of the poor results of the weakest students remain (Boulhol and Sicari, 2013a). From this standpoint, the policy of "priority" education (see below) carried out since the early 1980 s to improve the level of education in disadvantaged areas has been a failure.

Figure 12. Inequality of PISA results between students

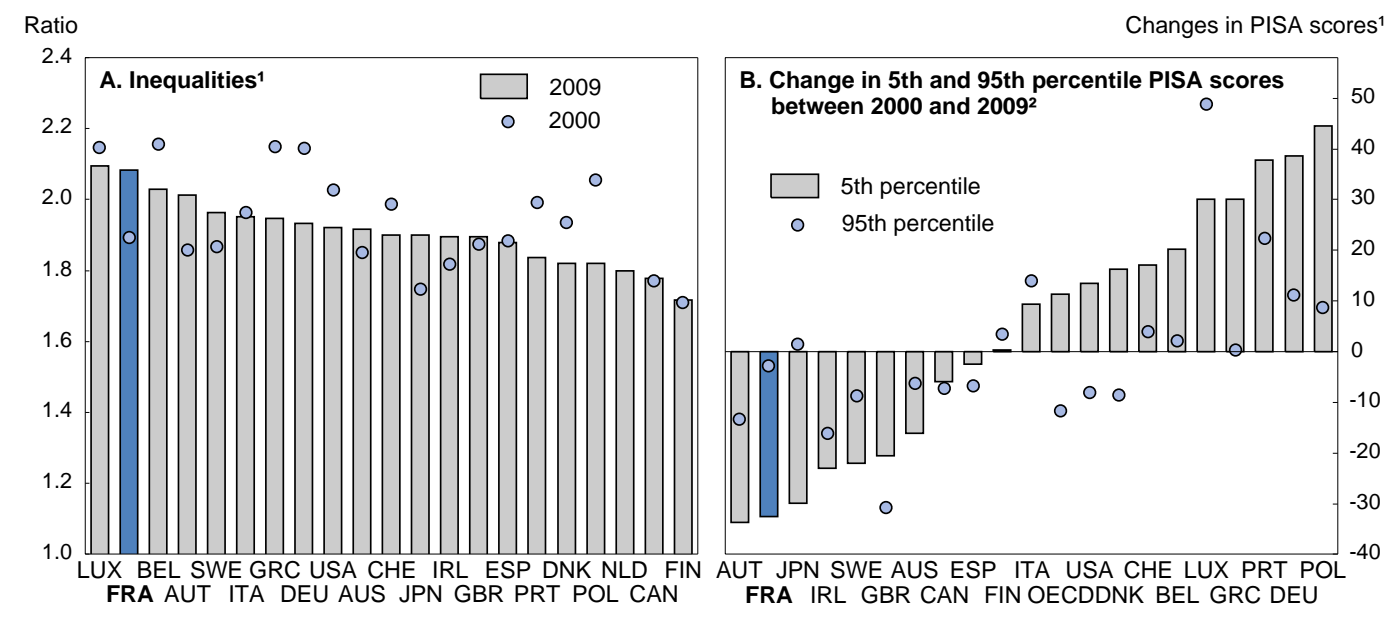

1. Panel $A$ shows the ratio of the average score of the top $5 \%$ of students to the average score of the bottom $5 \%$. For panels $A$ and $B$ alike, scores represent the average of proficiency in reading, mathematics and science.

2. Unweighted average for the OECD.

Source: OECD, PISA 2009 Results database.

Figure 13. PISA scores of the poorest-performing students (10th percentile)', 2009

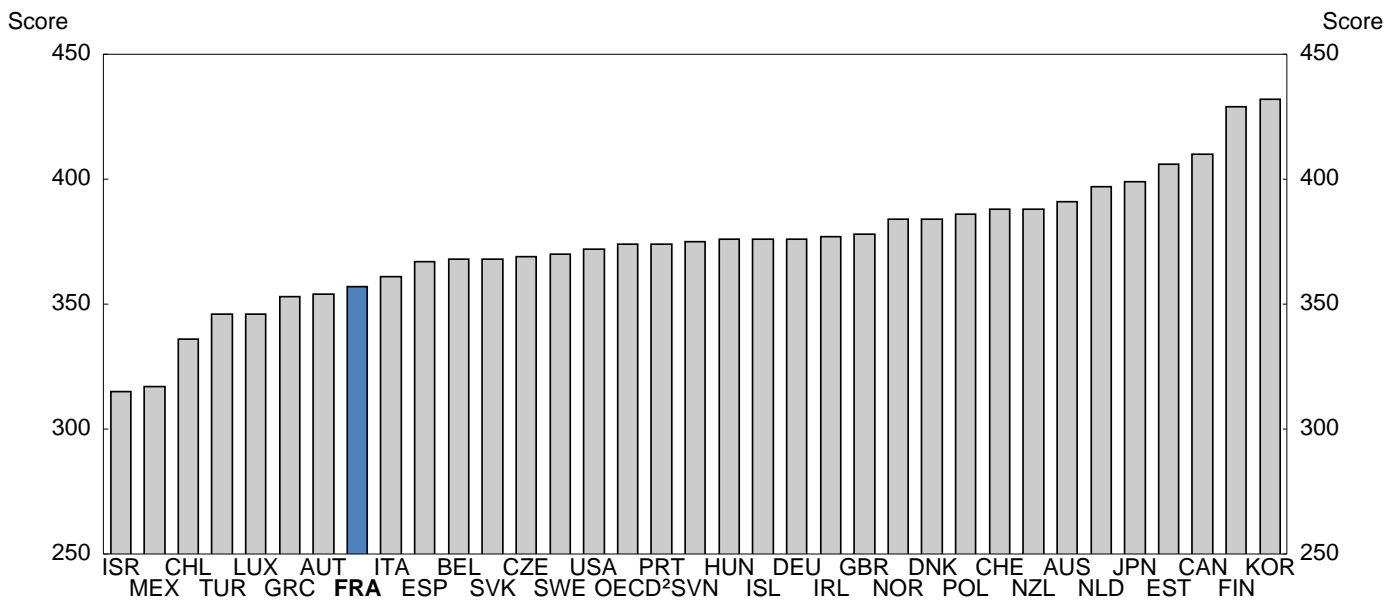

1. Average of scores obtained for proficiency in reading, mathematics and science.

2. Unweighted average.

Source: OECD, PISA 2009 Results database.

In France, inequalities of opportunity seem to be greater than elsewhere. The influence of social background on children's reading performance has increased and is one of the largest in the OECD 
(Figure 14). ${ }^{7}$ Improving the education system's performance therefore becomes an eminently social issue, entailing a battle against school failure in order to reduce inequality. International experience shows that it is possible to limit educational inequality drastically without penalising the performance of the best students. The paradox of France, relative to the other OECD member countries, is that it carries out policies that perpetuate or fail to bring down sharp scholastic inequalities at an early stage but significantly correct induced market income inequalities later through a costly system of social protection.

Figure 14. Relationship between student reading performance and socio-economic background

\section{Estimated slope of the relationship between student performance on the reading literacy scale and the PISA index of} economic, social and cultural status (ESCS)

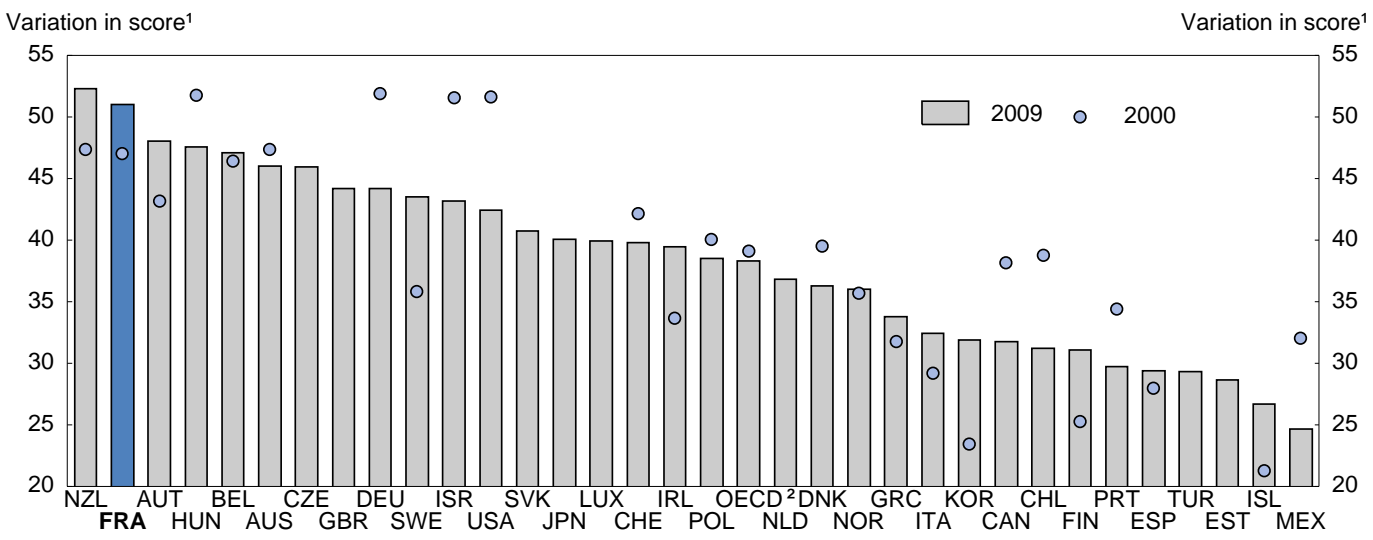

1. Variation in score associated with a one-point increase in the PISA index of economic, social and cultural status.

2. Unweighted average of 26 OECD countries.

Source: OECD, PISA 2000 Results and PISA 2009 Results databases.

\section{Priority should be given to intervening early in the educational process}

Fighting effectively against school failure entails concentrating the resources of national education, and of "priority" education in particular, at an early stage in the process - in nursery and elementary school, if not in very early childhood (Figure 15). This is the conclusion reached by all of the research into the effectiveness of policies to counter school failure (Heckman and Carneiro, 2003; Maurin, 2007). In contrast, corrective measures at later stages probably have only scant benefits. Actions taken during early childhood have long-lasting effects that can enhance learning abilities and reduce delinquency. Their effectiveness is attributable essentially to the increased returns on subsequent investment that such measures generate: learning is a cumulative process; in short, human capital is synergistic (Heckman and Carneiro, 2003). Moreover, returns on investment at an early stage are highest in respect of children from disadvantaged backgrounds, where the development of interpersonal skills and discipline gets little encouragement (Heckman, 2008). Thus, measures targeting very young children from disadvantaged backgrounds raise no equity-efficiency tradeoff: such investments are highly beneficial economically and lessen inequality.

7. Social origin is measured by student responses to questions about their parents' education and occupations and family assets, such as the number of books owned by the family and access to a desk or table for doing homework; this PISA indicator is standardised so that its average value is equal to 0 , and its standard deviation 1, all OECD countries combined. 


\section{Figure 15. Rates of return on equal investments in human capital, by age of target group}

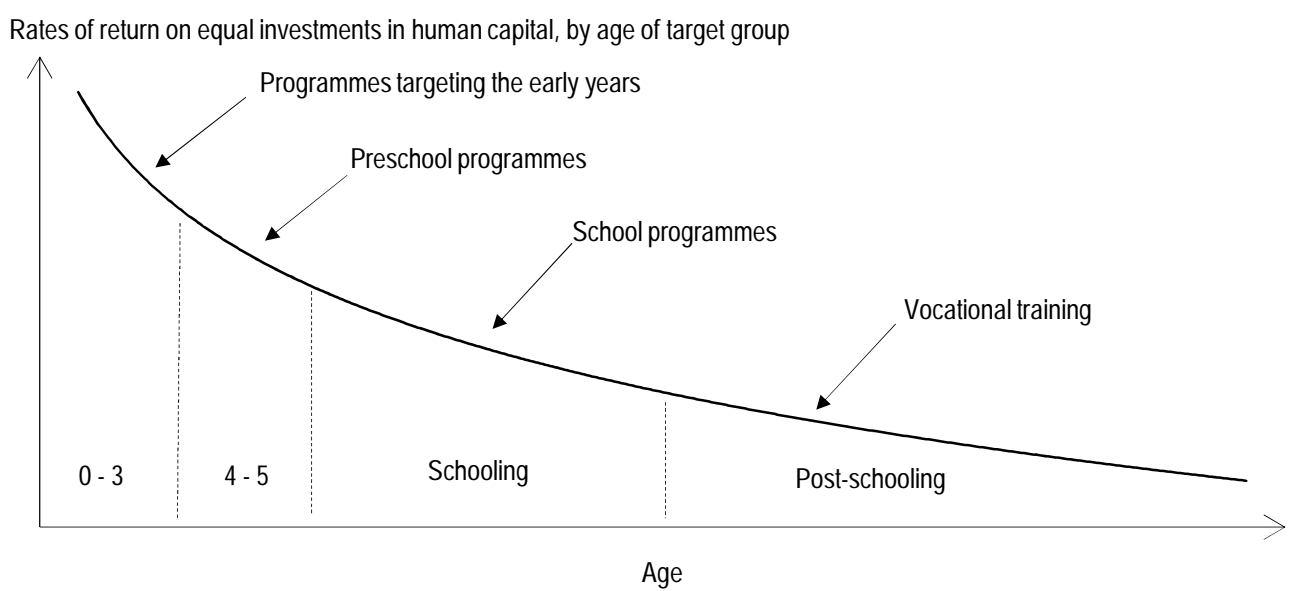

Note: The figure traces the returns on investments in human capital at various stages in the life-cycle for a person having given capabilities. All else equal, a one euro investment in a very young child's education yields very high returns, generally far in excess of the opportunity cost of government funds, and much greater than a similar investment for an adolescent, which in turn yields greater returns than a euro invested in an adult.

Source: J. Heckman (2008), "Schools, Skills and Synapses", NBER Working Papers, No. 14064.

France is well placed with regard to resources allocated to pre-primary programmes, thanks to its high enrolment rate as from age three, and despite below-OECD average expenditure per pupil (Figure 16). In contrast, expenditure per child in primary school accounts for approximately half of what is spent on upper-secondary education, as compared to an OECD average of four-fifths (Figure 17). Insofar as the socially optimal strategy would be to equalise the (decreasing) rates of return on investment in human capital for the various programmes, the current allocation of resources is inefficient and should be re-geared in favour of primary school - a shift that would be consistent with the government's stated priorities. For example, the average number of hours taught per teacher is $17 \%$ higher in primary school than in the average OECD country but $8 \%$ lower in lower secondary (OECD, 2012d). It also seems that such a re-allocation could be facilitated by the elimination of numerous curriculum options in secondary school, which are costly and tend to increase inequalities as a means of disguised early selection.

Figure 16. Pre-primary education expenditure, 2009

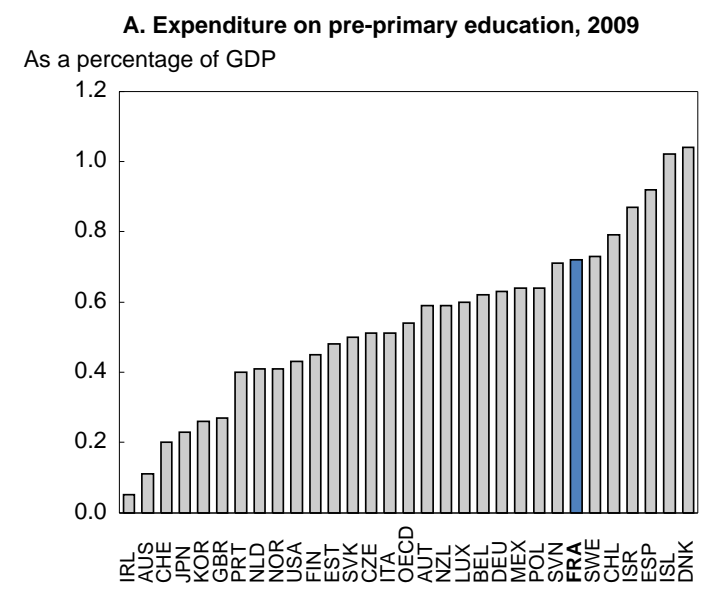

B. Expenditure per pupil vs. enrolment rates Enrolment rate at the age of 3 (2010)

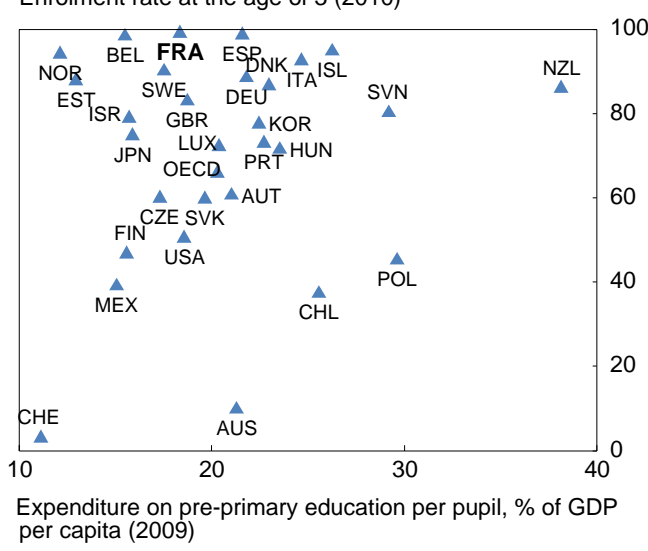

Source: OECD, Education at a Glance 2012 database. 


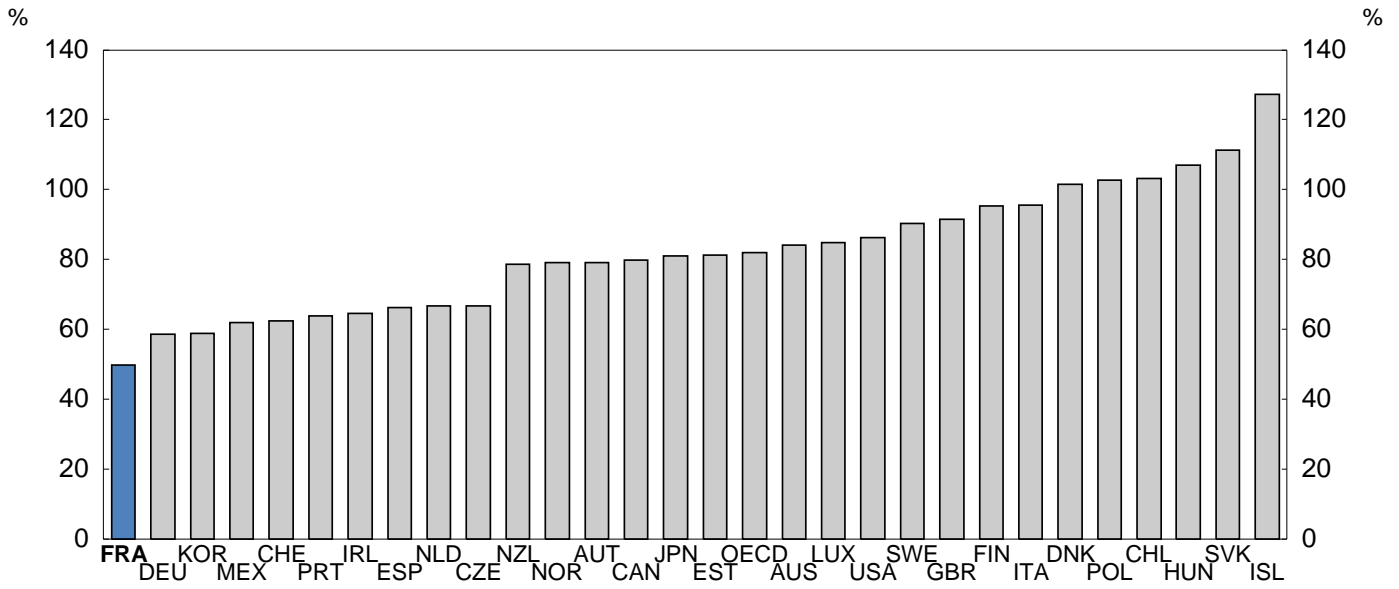

Source: OECD, Education at a Glance 2012 database.

The issue of the positive repercussions of schooling at age two is a debate that has not been settled (Maurin, 2007). Research using French data would seem to indicate that the positive effect on scholastic performance of enrolment at age two applies above all to children from disadvantaged backgrounds, and especially when they are foreign or of immigrant origin, insofar as it enables more effective assimilation of the French language and culture (Caille, 2001). Yet, the enrolment rate for two year-olds has been declining at a disturbing rate for a dozen years, from $35 \%$ in 2000 to $12 \%$ in 2011 . Above all, the départements with the most acute social problems are not those with the highest enrolment rates of two year-olds, contrary to the objective of the Act of 23 April 2005 (Cour des Comptes, 2010). The annual cost of applying this principle to the priority-education sector is roughly EUR 500 million. ${ }^{8}$

\section{Funding for priority education should be increased considerably}

Since the early 1980s, France has carried out a policy of positive discrimination aiming to combat social background-related inequalities at school. This policy of "priority" education zones (ZEPs) arose with an awareness of the urban segregation of suburbs and of the effect of that segregation on success at school. Since 1998, and especially as from 2006, priority education has been remodelled around the notion of networks (lower-secondary schools and lower-level schools in the same zone). The shift consisted of: first, improving teamwork and encouraging pedagogical continuity between primary and lower-secondary school in connection with the "common base of knowledge and skills" (Moisan, 2011); and, second, focusing resources more closely on networks in which the greatest difficulties are concentrated ("primary, elementary, lower-secondary and upper-secondary schools for ambition, innovation and success" - the so-called ECLAIRs) since 2011. There are also "scholastic success networks" (RRSs). At the beginning of the 2012/13 school year, roughly one in five students was enrolled in priority education. ${ }^{9}$

There has been no independent evaluation of these programmes using recent data. The Conseil Économique et Social (2011) has pointed out the repeated fits and starts of priority education policy,

8. Assuming that roughly 120000 additional two-year-olds should be enrolled in priority education zones would entail creating about 6000 jobs, i.e. a gross cost of approximately EUR 500 million. From this amount, the cost to government of current day care programmes for these children should be deducted.

9. Approximately 5\% of primary school pupils and 5\% of lower-secondary school students in the ECLAIR programme and, respectively, $12 \%$ and $15 \%$ in the RRS programme. 
leading to a piling-up of measures that render the system opaque. Bénabou et al. (2009) have shown that the conditions for attributing ZEP status were unclear and erratic and that the ZEP policy was inefficient, but that study covered old data (1982-1992). The fact is that it is in lower-secondary schools in ZEPs that the percentage of students with difficulties in writing has risen most sharply since the late 1990s: nearly a third of these students experience such difficulties, versus a quarter 10 years ago (Figure 18), which cannot be explained by the shifting social profiles of these schools (Daussin et al., 2011). Assessment of the priority education "networks" in terms of eliminating the education gap offers scant encouragement (MEN, 2010), in contrast to the rather positive official view.

\section{Figure 18. Evolving difficulties, by sector and education zones ${ }^{1}$}

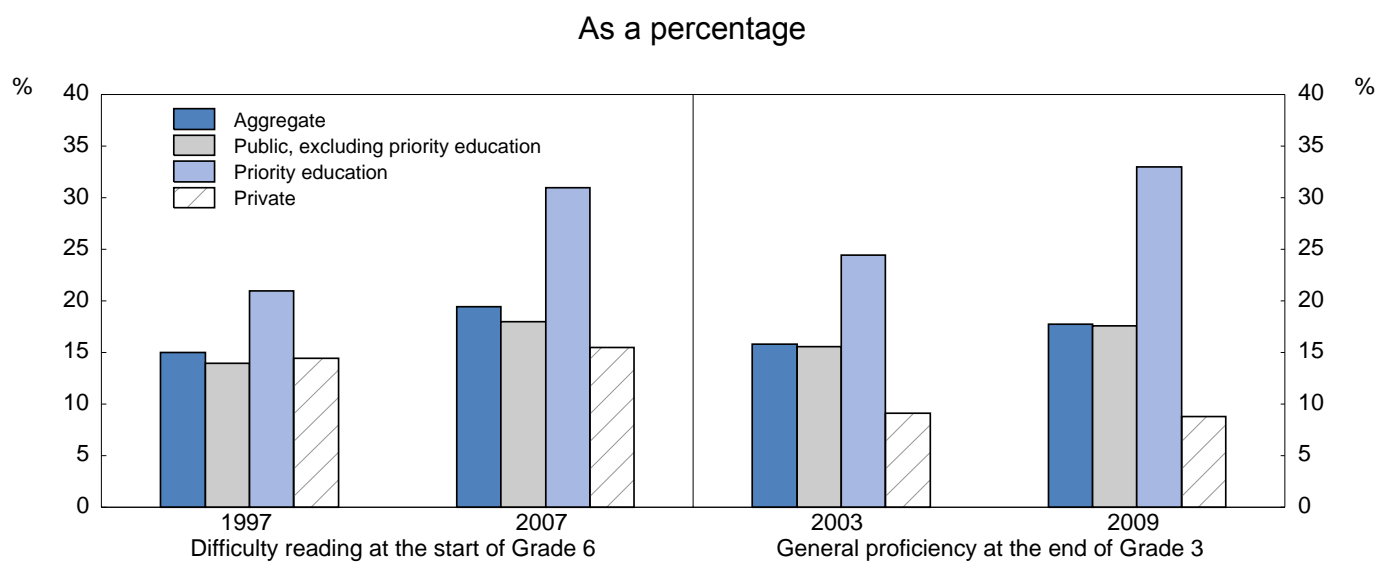

1. Interpretation: the percentage of students in priority education schools with reading difficulties at the start of Grade 6 increased from $20.9 \%$ to $31.3 \%$ between 1997 and 2007 .

Source: Daussin et al. (2011).

The disappointing outcomes of the priority education policy should not be surprising, given the low level of resources deployed. First, even today the quantification of these resources is very imprecise, whereas priority education has been targeting between 15 and $20 \%$ of students for the past 30 years. Revealing inadequate management, the cost of education policies - and of priority education first and foremost because of the challenges involved - has not been calculated, contrary to the spirit of the Framework Law on Budget Acts (LOLF), which prescribes that appropriations be allocated to targeted objectives (Cour des comptes, 2010; Bénabou et al., 2009). The Ministry of National Education's annual financial contribution to priority education is believed to be roughly EUR 1.1 to 1.2 billion $(0.06 \%$ of GDP) (Cour des comptes, 2010; Moisan, 2011). The Institut Montaigne (2004) considers this estimation deceptive, because it does not account for the fact that priority education primarily "attracts" teachers who are just starting their careers and who are therefore less costly, and it even evokes the possibility that discrimination is effectively negative (i.e. penalising ZEP pupils). Even sticking with the "official" figure of EUR 1.1 to 1.2 billion, this would represent an excess cost per student of only about $10 \%$.

Such an effort falls short of the challenges involved. The target of 15 to $20 \%$ of students is appropriate, since that is the proportion experiencing major difficulty at school. Increasing resources for those who are in even less favourable situations (enrolled in ECLAIR networks) is also judicious. But to convey an idea of the magnitudes involved, some successful initiatives abroad have deployed far greater funding of at least EUR 12000 (in 2012 prices) per child (OECD, 2007a), or roughly double France's current expenditures. By concentrating the funding on the most severely disadvantaged $15 \%$ of students 
between $4 / 5$ and $7 / 8$ years of age, the aggregate additional cost would come to EUR 2.6 billion a year, or $0.14 \%$ of GDP. ${ }^{10}$

This ambitious policy would imply raising priority education to another level. But the President's headline platform measure that the government intends to implement over his five-year term of office is the net creation of 60000 jobs in National Education for an estimated annual cost of EUR 2.5 billion, ${ }^{11}$ which is roughly the same order of magnitude. The opportunity afforded by the democratic mandate should be seized in order to concentrate the resources made available on the highest priority, which also holds out the most promising potential benefits: disadvantaged children at the end of nursery school and the initial years of elementary school. It can be argued that such a targeting would have decreasing returns, and that to generalise the initiatives carried out in other countries - admittedly successful but involving a far more limited scope - might not be as beneficial (Maurin, 2007). This policy, subject to a favourable assessment, could be implemented gradually, extending an initial experimentation phase to all of the ECLAIR networks.

A more radical approach would be to call into question the very idea of zones, which generate powerful stigmatisation effects (Merle, 2011), possibly stemming from the inadequacy of the resources deployed. Despite the "school maps" that assign students to schools according to where they live, and which were made more flexible in 2007 for secondary schools, school segregation is more pronounced in France than it is on average among OECD countries (Figure 19). First, 13\% of elementary school pupils and $21 \%$ of lower-secondary school students attend private schools; and, second, school districting induces residential location strategies (Maurin, 2004), which accentuate urban segregation and in so doing can have profound and harmful consequences. One solution preserving school maps that would avoid the excessive dichotomisation of zoning would be to abolish priority-education labels (ZEPs, RARs, ECLAIRs, RRSs, etc.) and grant schools supplementary budget allocations on the basis of the individual profiles of

Figure 19. School segregation is high in France

Distribution of disadvantaged students in disadvantaged, mixed and advantaged schools, 2009

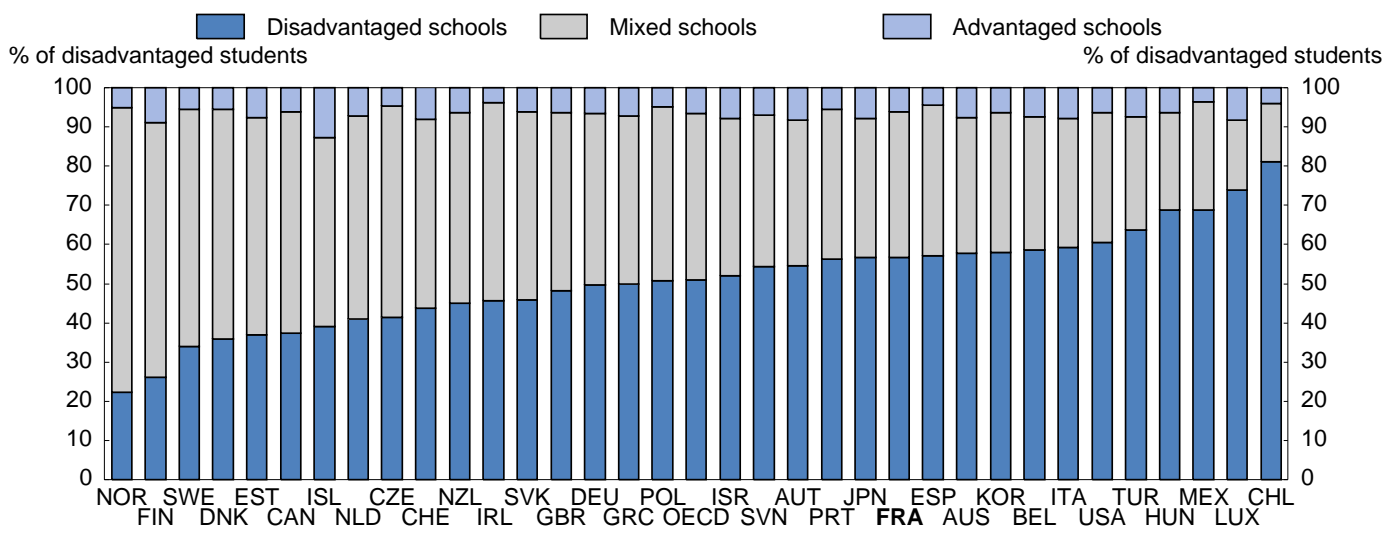

Source: OECD (2012), Equity and Quality in Education: Supporting Disadvantaged Students and Schools.

10. The current average cost per pupil is roughly EUR 6000 , and the current additional cost for priority education has been estimated at 10\%. Each cohort comprises roughly 800000 pupils, i.e. a population of 3.2 million between $4 / 5$ and $7 / 8$ years of age. The additional cost per pupil is therefore (12000$6000 * 1.10) * 3200000 * 15 \%=$ EUR 2.6 billion.

11. For a full year in 2017 according to estimates of François Hollande's presidential programme. 
the students attending them. In the Netherlands, elementary school funding is weighted by the number of disadvantaged students enrolled, which has improved the allocation of resources amongst schools (OECD, 2012b). This system of weighted financing has recently been developed in Chile and the United States as well.

\section{Make effective use of priority education resources}

How resources are used is as important as the amounts involved. To provide students from disadvantaged backgrounds with effective support, the emphasis should be put on three courses of action. Comparatively, the non-targeted measures to reduce class sizes that are often put forward yield poor returns (see Heckman and Carneiro, 2003 and OECD, 2012b for other references).

First, the aim should be to enhance the quality of teaching staff in disadvantaged schools, which would have a major impact on student performance. All studies concur on this point: more than any of the other levers of public action, teacher quality is the factor that most influences student performance (OECD, 2005). ${ }^{12}$ Priority education establishments are those that are the least well served in this respect: due to the unattractiveness of the incentives offered, a quarter of all teachers in the "success ambition networks" (réseaux ambitions réussites, RARs), the predecessors of the ECLAIRs between 2006 and 2010, were aged under 30 (compared to $10 \%$ outside priority education) in 2008, and over a third of them had worked in the same establishment for less than two years (MEN, 2010). Achieving improvement calls for (OECD, 2012b): strong financial incentives that can attract competent teachers; working conditions that are capable of enhancing their effectiveness and that will help retain them; independence of schools with regard to recruitment; specialised training focusing on the skills and knowledge required to work with children with learning difficulties; support from a management team providing continuing education and coaching; and a multi-pronged approach combining more intensive instruction supervised by a teacher and complementary action by a specialist teacher and a multi-disciplinary team, as in Finland (see OECD, 2007b, Box 4.2). Beyond priority education, a teacher's salary is equal to $77 \%$ of the salary of an average graduate, compared to $86 \%$ in OECD countries (Figure 20, Panel A). The authorities must remain vigilant in this respect, because difficulties in teacher recruitment have emerged in recent years despite high levels of unemployment, perhaps reflecting teaching's loss of attractiveness. It should be possible to increase salaries at constant overall costs by rationalising other current expenditure items, in particular administrative costs, which are high (Figure 20, Panel B).

An effective management team is the second most important aspect after teacher quality (Augustine et al., 2009). Besides the need to give primary school principals greater authority (see below), the emphasis needs to be placed on their selection and training as well as on the support given to them (OECD, 2012b). Their training needs to focus on general skills in improving learning, teaching and teamwork as well as on the specific knowledge needed to manage the problems inherent in disadvantaged schools. It is therefore essential to offer them sufficient incentives (salaries, career prospects, working conditions). It is also important to put in place objective monitoring of schools' performance and to take remedial action with regard to those reporting persistently poor performance. Ontario (Canada) and Ireland have adopted good practices in this respect (OECD, 2012b).

12. For example, according to Rivkin et al. (2001), the impact of changing from an average teacher to one ranked in the top $15 \%$ (i.e. a change corresponding to an improvement of a standard deviation in teacher quality) in terms of their students' results is equivalent to that resulting from a reduction of 10 in the number of students per class. All things being equal, having good teachers at primary school substantially improves performance at university and future earnings, and therefore one's entire life (OECD, 2005). 
Figure 20. Primary and secondary school teacher salaries, 2010

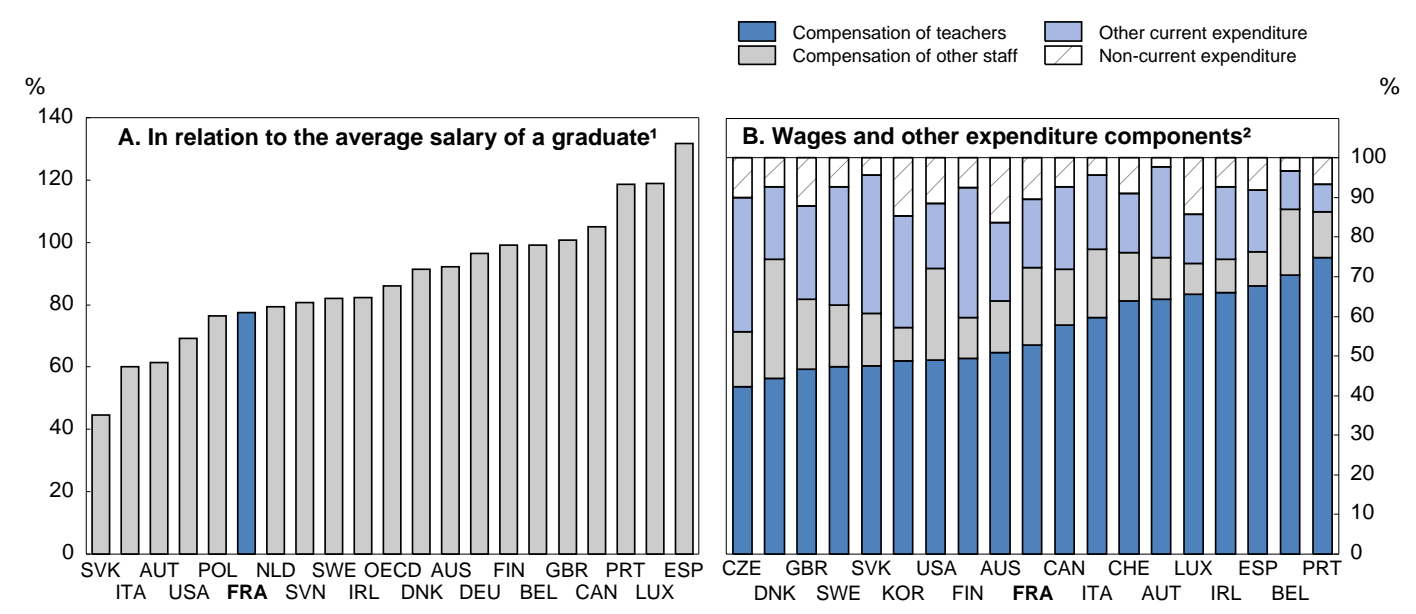

1. Basic annual salary of teachers in public establishments compared to the income of a graduate aged 25 to 64 working full-time all year.

2. As a percentage of public and private expenditure on the operation of teaching establishments.

Source: OECD, Education at a Glance 2012 database.

Third, the involvement of parents is an essential factor in success at school. Priority education schools must step up their efforts to forge links with the least involved parents. Some strategies have proved their worth, notably in the Netherlands, where a programme has been developed to encourage immigrant parents to get involved (OECD, 2012b). It includes home visits by teachers, lessons (language lessons in particular) and information for parents. In France the mallette des parents initiative in secondary schools is well worth mentioning and has undergone assessed trialling, which highlights the success of this measure (Avvisati et al., 2010). It allows support to be given to parents by helping to explain to them the meaning and challenges of schooling, how schools operate and their expectations of parents. This low-cost scheme (costing around 1000 to 2000 euros per school) has achieved encouraging results in terms of reducing absenteeism and violence in schools. A similar programme should be developed for primary schools, but strengthened and targeted on priority zones.

\section{Improve teacher training}

Initial teacher training in France remains too academic, is not sufficiently oriented towards instruction in teaching methods and does little to develop the non-cognitive capacities of children that are so essential for their success (OECD, 2012c). Teaching methods place too much importance too soon on grading, a practice that places stress on students, particularly those with learning difficulties who may start to fear and then reject school. The French method of training teachers is quite unique in Europe, with professional training given after the teacher qualification examination according to the so-called "consecutive" model, whereas formal and professional training in other countries is often provided at the same time by combining coursework with practical work experience (EAO, 2009). It is that model that has been adopted in the government's proposed reform, which will be in effect as from the 2013-14 academic year. In Finland, teachers' capacity to transmit knowledge and adapt their lessons to students' levels is an integral part of the programme and is one of the key elements explaining the success of the system. Many OECD countries are strengthening these aspects of teacher training. ${ }^{13}$

13. http://www.assemblee-nationale.fr/13/rap-info/i4033.asp. 
Continuing professional training is also inadequate and poorly targets the real needs of teachers (CESE, 2011). In France, as in other countries, such training is compulsory, although in practice participation is optional. In Spain, Luxembourg, Poland, Portugal, Slovenia and the Slovak Republic, continuing training, although optional, is clearly taken into account in career advancement and salary increases (EAO, 2009). According to the Institut Montaigne (2010), only a third of teachers avail themselves of continuing training each year in France, whereas best international practices suggest that $10 \%$ of the working time of teachers should be given over to such training, in particular to allow exchanges based on colleagues' experience and to gain access to specialised "coaches". ${ }^{4}$

\section{Give school principals greater independence}

Taking greater account of the heterogeneity of local circumstances requires schools to be given greater independence. Such independence is necessary to ensure that their managers, as in other countries, can adjust programmes, teaching methods and support measures to the specific needs of students, and more generally improve the functioning of their schools. In France, however, primary school management is subject to one of those particularities inherited from the past which leaves their principals little room for manoeuvre. Unlike lower-secondary schools, which since 1985 have been local public teaching establishments (EPLEs) with some financial and administrative responsibilities (which should also be extended) and with genuine teaching and educational independence, public primary schools are not legal and moral persons nor are they financially independent; from a legal standpoint they are municipal services (Obin, 2007). In this respect they still suffer from inadequate rationalisation of resources due in part to the continued existence of a great number of small municipalities: the Ministry of National Education has been conducting a relatively successful drive to persuade small schools to merge at the inter-communal level (and not only in rural areas).

Furthermore, while secondary schools are managed by a head supported by a team of colleagues, primary school principals are on their own and simply tasked (without any line responsibility and in most cases working on this part time) with administrative and teaching duties while retaining their status as teachers. Hence, their responsibilities are unclear: they often suffer from a lack of legitimacy and have neither the authority they need to assume such teaching responsibilities nor sufficient resources to fulfil their administrative duties (Obin, 2007). Primary school principals report to an inspector who assesses them (according to the same criteria as teachers, but in any event without any specific protocol) and also to the mayor. Giving them more authority and the accountability that would go with it would go hand in hand with changing the status of schools from municipal services to EPLEs (Institut Montaigne, 2010). The Law of 13 August 2004 makes this possible but is not applied (the enabling decree has never been published).

\section{Review the school day and school year}

These difficulties are exacerbated by a school day and school year that are totally mismatched to children's biorhythms. The system is characterised by one of the longest school days in the OECD area due to the concentration of a high number of hours of instruction into a small number of days of lessons (OECD, 2012d). In the Netherlands, for example, the school year is spread over 40 weeks, whereas in France it amounts to only 35 weeks (and the OECD average is 38 weeks). Furthermore, the four-day week is too short and tiring for students, and does not allow enough time for those who for a time fail to keep up with their studies to eventually catch up. It would therefore be advisable to lengthen the school week, to reduce the number of hours of classes a day and to shorten school holidays. The government intends to extend it to four and a half days; five days is standard in almost all other OECD countries. These changes

14. The 78000 students enrolled in CPGE benefit from an average advantage of around EUR 5000 compared to university students. 240000 students are enrolled in STS and have additional funding of EUR 3600 a year on average, i.e. an envelope of EUR 860 million. 
are a step in the right direction. They would inject greater flexibility into the organisation of the school day and would enable more numerous individual support sessions and at better times than those currently offered, for example, during the lunch hour.

\section{The use of year repetition should be drastically reduced and support for schoolwork improved}

Another feature of French education is intensive recourse to grade repetition. It is both ineffective and costly. In France, some 37\% of students had repeated a year at least once by the time they were 15 in 2009 , compared with an average of $13 \%$ in OECD countries (Figure 21). Repeating a year is ineffective in remedying long-term learning difficulties. Firstly, a student who fails to keep up loses several months of the school year and often repeats the same mistakes the following year. Second, repetition tends to stigmatise students in difficulty, thereby adding to drop-out rates (OECD, 2012d). It is extremely costly due to the longer period of studying it entails, amounting to some 2 billion euros in 2009 (Cour des comptes, 2010). It illustrates a certain inefficiency of the current allocation of resources.

Figure 21. Grade repetition is very high in France

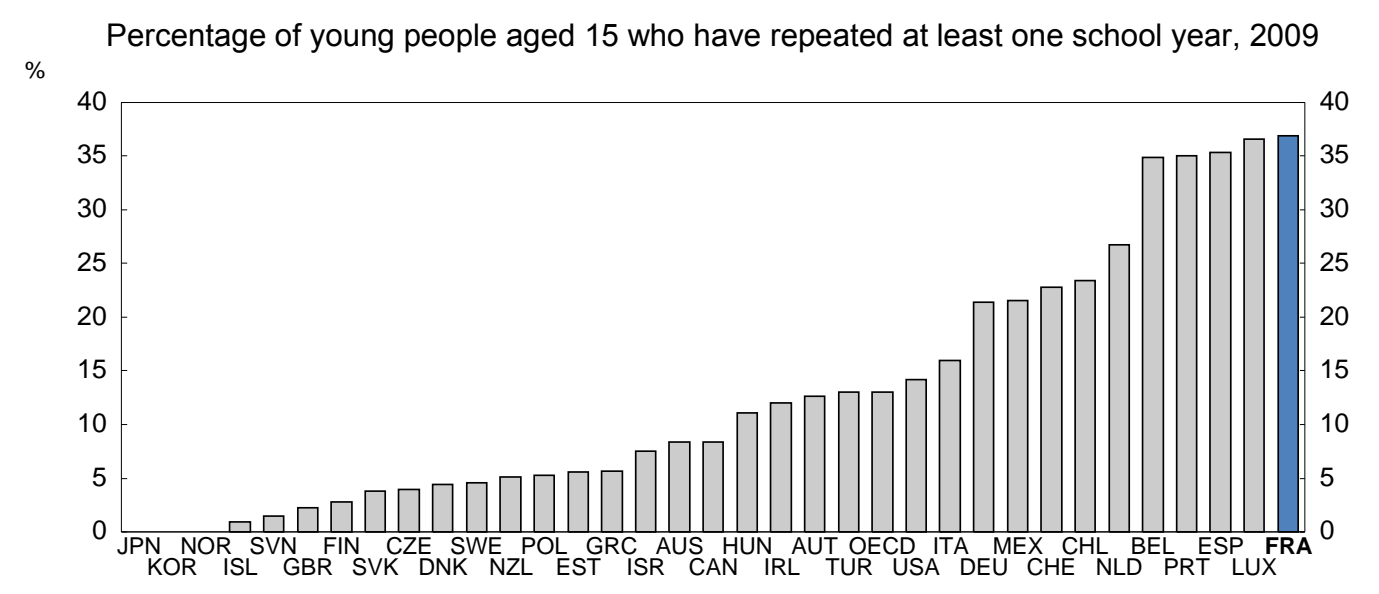

Source: OECD (2012), Equity and Quality in Education.

The Ministry recognises that grade repetition is an inappropriate instrument with which to fight failure at school. In fact, repetition rates are trending downward: the proportion of students who have fallen behind by the end of primary school, for example, dropped from 52\% in 1960 to $37 \%$ in 1980 and $13 \%$ in 2010. However, the authorities are finding it hard to accelerate the trend, as shown by the difference between the objectives announced and the actual outcomes (Table 2). Efforts should therefore be stepped up to raise the awareness of stakeholders - teachers, school councils, parents, etc. - of the negative implications of this practice.

Reducing year repetition also requires teaching to be tailored more closely to individual needs. The aim is to remedy shortcomings as they are identified during the year by providing support for students experiencing difficulties and by adapting teaching methods and programmes to work in small groups of students. However, even if the systems designed to take account of students' learning difficulties at a more individual level are constantly growing in number, they are poorly co-ordinated and therefore a source of confusion (Cour des comptes, 2010; Claus and Roze, 2009). 
Table 2. Rate of year repetition

\begin{tabular}{lc|cc|cc|ccc}
\multicolumn{10}{c}{ Per cent } \\
& $\begin{array}{c}2008 \\
\text { Actual }\end{array}$ & $\begin{array}{c}2010 \\
\text { Forecast } \\
\text { APP 2010 }\end{array}$ & $\begin{array}{c}2010 \\
\text { Actual }\end{array}$ & $\begin{array}{c}2011 \\
\text { Forecast } \\
\text { APP 2011 }\end{array}$ & $\begin{array}{c}2011 \\
\text { Actual }\end{array}$ & $\begin{array}{c}2012 \\
\text { Forecast } \\
\text { APP 2012 }\end{array}$ & $\begin{array}{c}2012 \\
\text { Updated } \\
\text { forecast }\end{array}$ & $\begin{array}{c}2015 \\
\text { Target }\end{array}$ \\
\cline { 2 - 10 } CP (age 6) & 3.7 & 1.5 & 3.5 & 1.0 & 3.4 & 1.5 & 2.9 & 2.0 \\
CE1 (age 7) & 4.1 & 2.0 & 4.2 & 1.0 & 4.0 & 2.0 & 3.5 & 2.0 \\
CE2 (age 8) & 1.8 & 1.3 & 1.8 & 1.0 & 1.6 & 1.0 & 1.3 & 0.5 \\
CM1 (age 9) & 1.2 & 1.0 & 1.3 & 1.0 & 1.1 & 0.8 & 0.8 & 0.5 \\
CM2 (age 10) & 1.6 & 1.2 & 1.6 & 1.0 & 1.5 & 1.2 & 1.2 & 1.0 \\
Sixième (age 11) & 5.0 & 3.5 & 3.4 & 2.5 & 2.8 & 2.0 & 2.0 & 1.0 \\
Cinquième (age 12) & 2.3 & 1.5 & 1.9 & 1.0 & 1.5 & 1.3 & 1.3 & 0.5 \\
Quatrième (age 13) & 3.6 & 2.5 & 2.7 & 2.0 & 2.1 & 1.5 & 1.5 & 1.0 \\
Troisième (age 14) & 4.7 & 3.8 & 4.2 & 3.5 & 3.7 & 2.5 & 3.0 & 2.0 \\
\hline
\end{tabular}

Source: Annex to the draft Finance Act for 2010, 2011 and 2013, section on teaching in schools; Interministerial mission on annual performance plans (APP).

\section{Better guidance}

The educational and career guidance system is one of the weak links of the school-to-work transition in France. In the light of youth unemployment that is both pervasive and deeply entrenched and the dominant role played by the educational path in accessing employment, guidance provided at the end of lower secondary school evokes great apprehension because it signals, even determines, students' aptitudes. Often experienced as a failure, approximately four students in ten consider that they endured rather than profited from their guidance (HCE, 2008). In fact, this guidance is essentially failure driven, in the sense of reflecting a desire to choose the best and brightest rather than to offer everyone the chance to succeed (HCE, 2008; Cour des comptes, 2010; Cahuc et al., 2011).

Many secondary-school students, especially in underprivileged areas, have only a vague sense of the trajectories offered by a given type of training. While students who choose the general programme in upper-secondary education settle on a stream after a first year of general courses, those who opt for technological or vocational programmes must select from a myriad of courses as of the end of lower-secondary school before the abrupt transition into upper-secondary education. It would be better if these students also benefited from an initial transition year at the beginning of upper secondary (Galland, 2009).

This problem is exacerbated by the fact that the Guidance Counsellor/Psychologists (conseillers d'orientation-psychologues, CO-P) often lack the skills and familiarity with employment opportunities required to impart the relevant information and effectively advise students (HCE, 2008). For equivalent educational attainment, guidance is highly influenced by the socio-professional class of the parents, in particular because children from disadvantaged backgrounds lack the requisite information, confidence, or ambition, or self-censor their aspirations, and CO-Ps are not able to counterbalance this influence - or they, themselves, unconsciously participate in this cycle of social replication (HCE, 2008). Many experts believe that teachers in France are too far removed from the world of business. While switching disciplines during higher education is very rare in other OECD member countries $3 \%$ at most in Denmark and New Zealand), $15 \%$ of students in France abandon their initial choice of field of study in university and switch to more technical training of the IUT or STS type (see below) (OECD, 2009).

However, recent measures reflect movement in the right direction, though their implementation is still embryonic. The 24 November 2009 law proposed a redesign of the guidance system and life-long 
professional training. In particular, it was intended to deliver a better public guidance system and improvements to the status and recruitment of CO-P. The goal is to prod CO-P missions to be more in tune with economic and social realities. The terms and organisation of the recruitment process were modified in March 2012 to place more emphasis on the required knowledge of the economy and national, sectoral and territorial characteristics of the job market.

These efforts should be pursued in three directions. First, reform of the CO-P must go much further, with a clear separation between the functions specific to guidance, to be developed by specialised training, and psycho-social functions that require other skills. The activity of these future guidance counsellors must also be better controlled than is the case with the CO-P (HCE, 2008). Their recruitment should be expanded to professionals with experience with business (Institut Montaigne, 2012) or with labour-market integration. Second, teachers must receive appropriate training to be more involved in the guidance given to students, as is notably the case in Germany, Denmark and the Netherlands (Institut Montaigne, 2012). Teachers today tend to avoid getting involved in guidance and are poorly equipped for it, even though they receive a lump-sum stipend for monitoring and guidance (HCE, 2008). In general, it is a matter of creating more room within education for an initiation into the world of work. Third, guidance missions must be better co-ordinated. This would involve, for example, a meshing or even merging at the regional level of the management bodies that jointly perform the current functions of information and guidance centres, of the Ministry of Education's General Integration Mission (MGI) and the PES (local missions, see below).

\section{Young people in the higher education system}

Thirty years ago France lagged behind many countries with merely $17 \%$ of age cohorts obtaining a tertiary qualification, compared to an OECD average of 20\%. Today, with $43 \%$ of $25-34$ year olds holding such a qualification, compared to an average of $38 \%$ in OECD countries, France is outranked by only 11 countries compared to 17 previously (OECD, 2012d). This "mass" entry into higher education has not reduced the value of diplomas in helping to secure access to employment (Figure 22, Panel A; Le Rhun and Minni, 2012). In contrast, against a background of very high unemployment over the past 30 years, returns in the form of higher real salaries for higher levels of educational attainment have tended to fall (Panel B).

Figure 22. Unemployment rate and real salaries from one to four years after initial training

All working hours, in constant 2011 euros

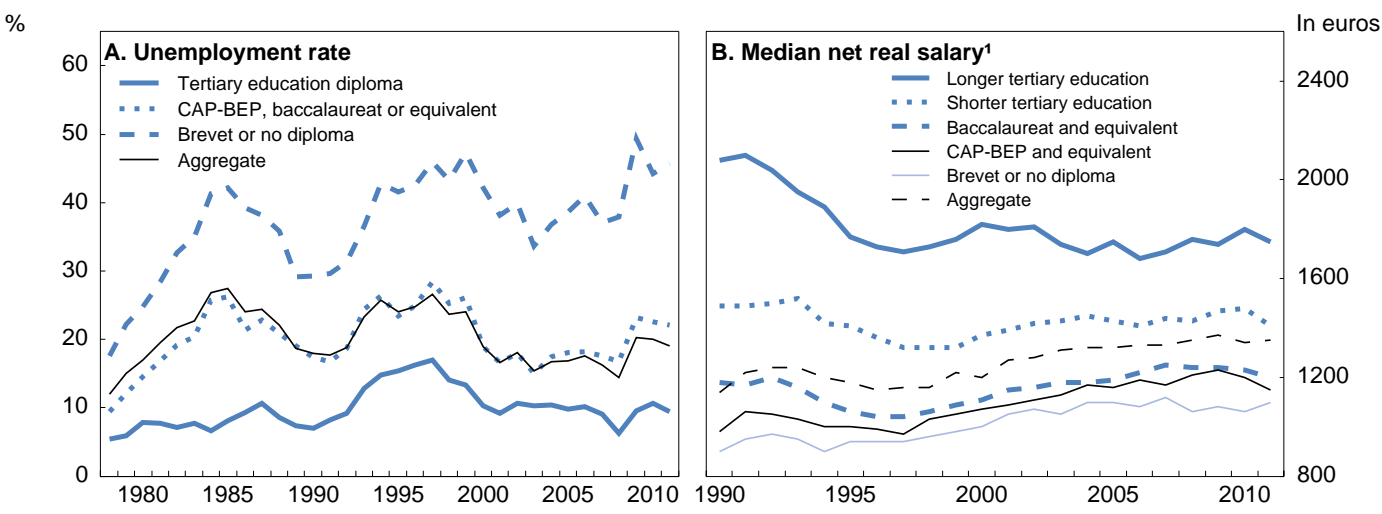

1. Series break in 2003.

Source: INSEE, Employment surveys. 


\section{Rebalance public funding in favour of universities and raise enrolment fees}

This progress, however, should not obscure the fact that serious problems remain. French higher education must face up to challenges regarding financing, equal opportunities, efficiency and quality (OECD, 2012d). The sector is highly segmented and its complexity clear to see in the fact that it comprises over 400 establishments reporting to 11 ministerial supervisory agencies and spread over some 650 sites (Cour des comptes, 2011). The reason for this dispersion lies in the large number of different alumni groups that dominate the sector, which leads to widespread inaction and inertia. The higher education sector is made up of highly competitive elite establishments (the grandes écoles and their preparatory classes, CPGE), short vocationally oriented training courses (university technology institutes (IUT), higher technician sections (STS) in schools) and universities (research and training units (UFR) in the strict sense of the term). While there are tight admission criteria, high levels of student and teacher commitment to the educational process and sufficient resources in the first two sectors, universities admit all secondary school graduates with no selection and get less funding per student, even if financial efforts for the universities are being made. The proposed educational steering act would bring the CPGE closer to the universities by asking CPGE students to enrol in a university (and for non-scholarship students to pay registration fees).

Despite recent efforts, the financial resources of French universities remain insufficient compared to foreign universities and also in relation to other French teaching establishments: in per student terms, their expenditure is 36\% lower than that of STS and 50\% lower than that of the CPGE (Figure 23). In the case of the grandes écoles, the data the Ministry has at its disposal are not sufficiently detailed to be able to determine aggregate expenditure. Differences in the allocation of funding to establishments can be justified only on the grounds of efficiency. The current disparities are highly inequitable. The advantage in terms of per capita public funding for the CPGE and STS alone, for example, amounts to EUR 1.25 billion a year, comparable to the upper limit of the budget allowance for "priority" education. Furthermore, this advantage is regressive, given the over-representation of children from privileged backgrounds in these streams. Beyond differences in public spending, the success of the grandes écoles has been built on a very selective environment and relatively significant autonomy. Because the university system lacks these attributes for the most part, the overall system is dualistic, with the universities being to a fairly large extent cut off from the elites, especially as regards the first cycle of higher education.

Figure 23. Spending per student for the various higher education sectors, $2009^{1}$

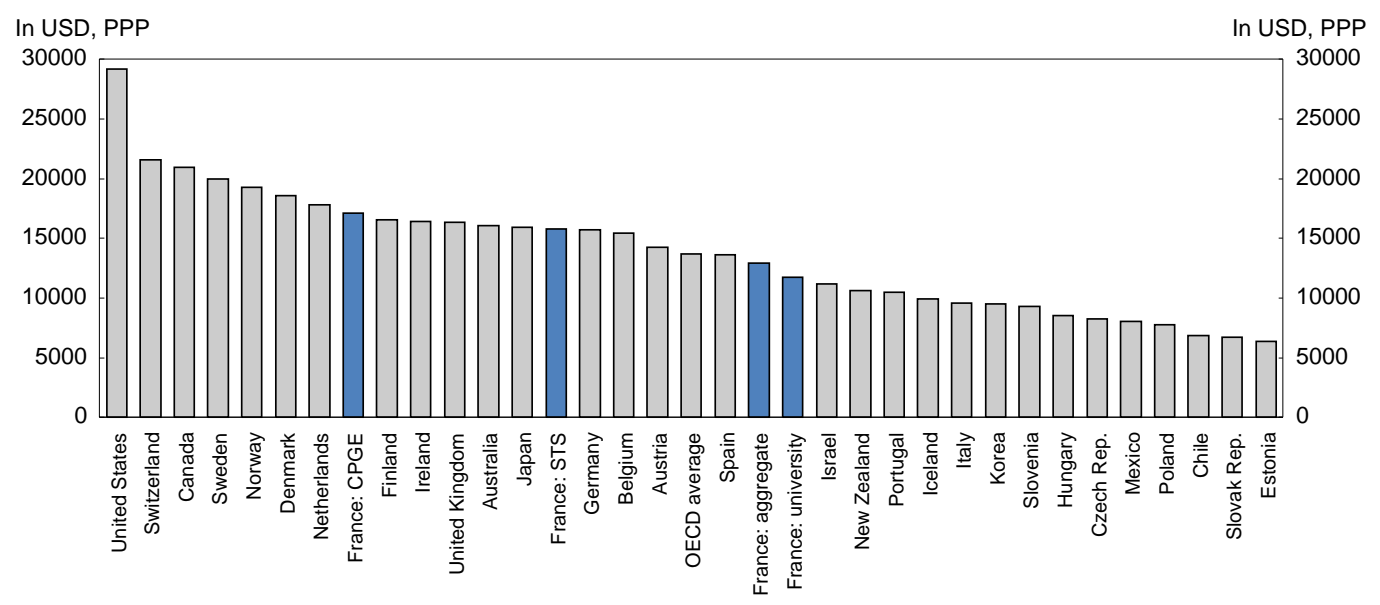

1. For France: preparatory classes for the grandes écoles (CPGE) and higher technician sections (STS).

Source: OECD, Education at a Glance 2012; Ministry of national education - DEPP, L'État de l'école 2010, 2012.

Raising tuition fees is more or less unavoidable if the quality of the university system is to be improved. The share of private financing is very low, primarily due to the very low level of such fees, 
which the Ministry set at 181 euros a year for a bachelor's degree for example, in 2012-13, and represent overall a twentieth of higher education expenditures. However, the benefits of higher education are primarily private, given that students are the first to benefit from their degrees. To the extent that disadvantaged social groups are less well represented in the tertiary student population, this primarily public financing tends to be regressive. An increase in tuition fees would need to be accompanied by improved access to student loans repayable out of future earnings and/or reinforcement of the grants system. These contingent loans offer the advantage of not passing on the cost of studying immediately to the student but rather to the future employee who will have profited from studying. Several OECD countries propose means-tested grants and loans repayable out of future earnings, including Australia, Canada, Chile, the Netherlands, New Zealand, the United Kingdom and the United States.

\section{Increase the independence of universities}

To optimise the use of the additional resources needed, universities must be given greater independence and offered proper incentives (Aghion, 2011). Recent reforms have aimed at improving their efficiency. To remedy the fragmentation of the higher education system the higher education and research clusters (PRES) created in 2006 allow establishments to combine their resources with a view to generating economies of scale and enhancing their international profiles. In May 2012 there were 23 PRES covering 60 universities (out of a total of 83) and 13 other establishments (engineering schools, business schools, etc.). A law passed in 2007 (Loi relative aux libertés et responsabilités des universities, LRU) laid the initial foundation for the independence of French universities, notably with regard to management of their overall budgets, which nonetheless remains for a large part constrained and centralised. The Plan Campus, launched at the end of 2008 with funding of EUR 5 billion, covers the renovation of campus buildings. Lastly about two-thirds of the 2010 "investing in the future" programme (investissements d'avenir), with total funding of 35 billion over 10 years, will benefit the higher education and research sector. Within this envelope, EUR 15.35 billion is being allocated to "clusters of excellence" mostly, although not all, selected from among the PRES. However, the precise role of the PRES, which were to become the leading actors in the rebuilding of the university landscape, is unclear (Cour des comptes, 2011). It is therefore important to develop incentives that will help strengthen the clusters. The necessary increase in independence and allocation of resources should be made conditional upon achieving precise objectives in this area. The government would like to do away with the PRES and replace them by 30 "university communities".

Despite the LRU, the university system remains one of the most constrained in Europe, according to a comparative study conducted by the European University Association (Estermann et al., 2011) covering 26 countries and based on 30 criteria covering four specific areas. The United Kingdom has the most independent university system. France is ranked in $16^{\text {th }}$ position in terms of organisational independence, last but one for human resources and last for teaching (fields of study, number of students, selection, structure and content of diplomas, etc.) (Figure 24). Universities would benefit from greater latitude in setting tuition fees, selecting students and managing their human resources (recruitment and salaries). This would require enhanced management skills, including the introduction of more professional financial management, and could also facilitate the mobilisation of other sources of private financing. 

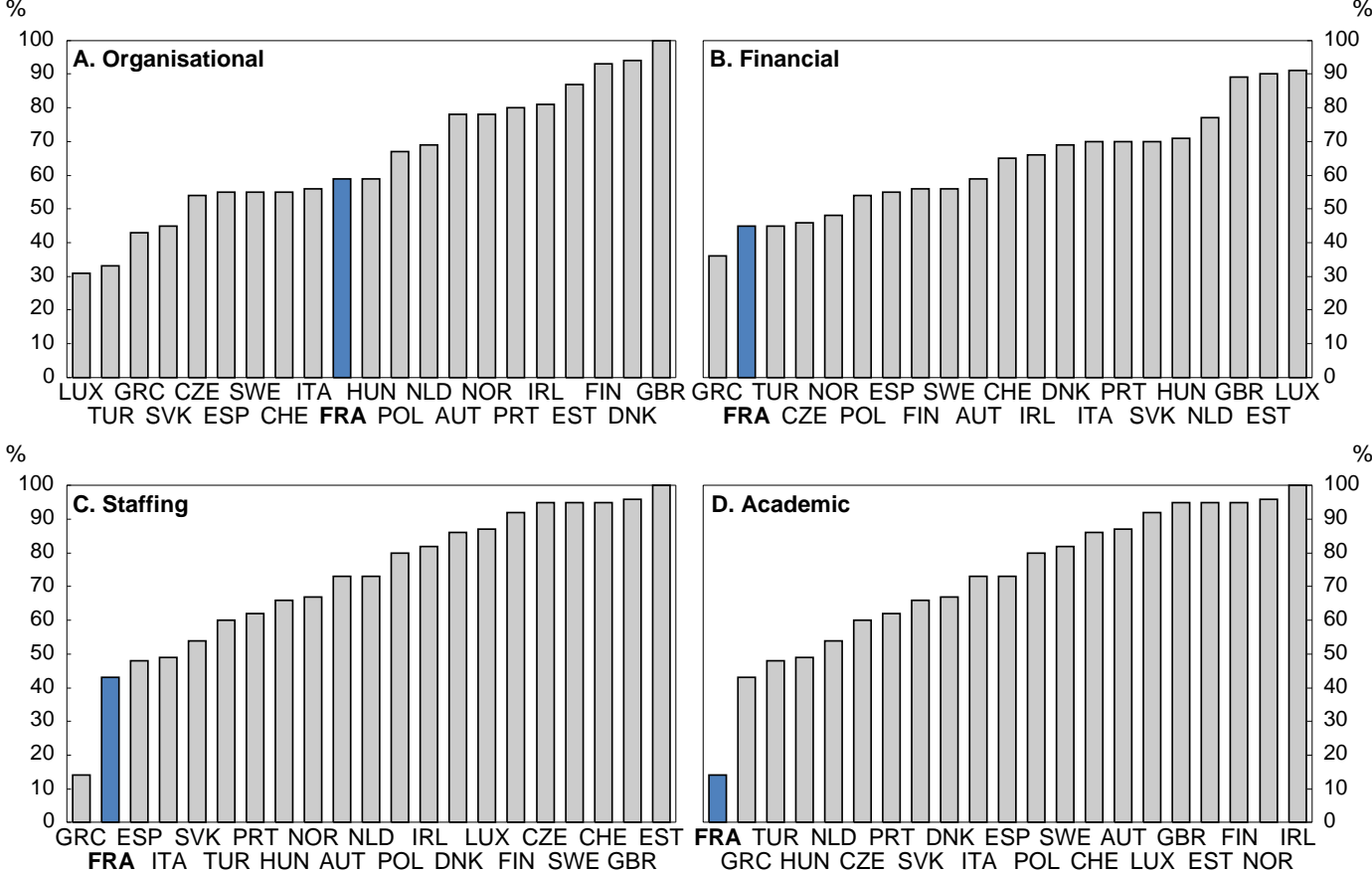

1. $100 \%$ is the highest degree of autonomy given to universities in the four areas reported in the figure.

Source: European University Association, 2011.

\section{Fighting failure at degree level}

The overall strategy should be aimed not only at creating excellent universities, but also at increasing the effectiveness and relevance of the teaching offered in all universities (OECD, 2012c). Only 52\% of students admitted to university progress to the second year: $23 \%$ repeat the first year, $19 \%$ change course and $6 \%$ drop out. The success rate for students from the professional and technological streams in the baccalauréat is very low, around $20 \%$. Students should be given more rigorous course advice before entering university to avoid costly repeating of years and leaving without gaining a qualification (OECD, 2012c). A yawning gap now exists between the secondary and higher education sectors, and many students have difficulty in obtaining the information they need to choose the type of course they wish to follow. Greater independence could encourage universities to improve the information they provide on job opportunities as well as the quality of their course advice. Strides have been made with regard to this particular information and advice, such as the creation of the Occupational Placement Assistance Office (Bureau d'aide à l'insertion professionnelle, BAIP), and these efforts should be pursued.

The "plan for success at degree level" was launched in 2008 for a period of five years with funding worth EUR 730 million, i.e. an average of around 200 euros per degree student per year. This plan is designed to provide tailored support for individual students. According to the Cour des comptes (2012a), however, the plan falls short because of the insufficient guidance provided by the Ministry and the lack of proper financial monitoring by the universities. The government intends to allocate 5000 out of the 60000 teaching posts created to the higher education sector by targeting the bachelor's level. It is important that as much weight be given to teaching as to research in the recruitment process, notably by fostering greater awareness of teaching criteria during the recruitment of teacher-researchers. 
Beyond rebalancing public funding in favour of universities and increasing their independence, the response to failure at degree level calls for the introduction of training courses that lead to a qualification such as vocational degrees, which account for around a quarter of degrees awarded. ${ }^{15}$ Aghion (2011) cites a couple of examples of universities in the United Kingdom, which, although much less reputed than the more prestigious universities in that country, achieve remarkably high rates of success for their graduates in finding employment as a result of their offering courses that are strongly focused on vocational rather than general and basic skills. In France, the success of the IUT and STS has been founded on developing short courses that lead to qualifications which are valued in the labour market, on student selection and on the allocation of greater resources, thereby making up for universities' weaknesses in those areas. Plans have been mooted to encourage or force the IUT and STS to admit more students from vocational and technological secondary education streams, although the priority for the latter is to improve guidance and training upstream (see below) and forge links with industry. Moreover, some courses do not give students enough job-related skills (Arts and Human Science graduates, for example, find it very difficult to enter the labour market, according to DARES, 2011) and need to be made more attractive to businesses.

\section{Fostering links between universities and industry}

Despite recent efforts, the higher education system has formed limited links with industry. As a general rule, while students receive good academic training, progress must still be made in preparing them for contact with the world of industry. The practice of work placements in firms must continue to be further developed. Increasing the contribution made by firms to the financing of universities is another major challenge. Amounting to a mere 7\% in France, the contribution by firms to the funding of higher education establishments is over $10 \%$ in many other countries (OECD, 2012d). Making universities more independent could increase their attractiveness to industry. Some recent initiatives are moving in this direction: the LRU of 2007 provides for the appointment of a manager from the firm to the governing board of tertiary establishments and for the creation within each university of platforms providing information, advice and support for the transition from university to work. Furthermore, the public career guidance service (see below) should provide detailed information on the job opportunities for the courses proposed by higher education establishments in order to improve post-secondary course choices.

\section{Promoting youth employment and facilitating school-to-work transition}

\section{France has had poor performance on the youth labour market for a long time}

Unemployment rates exceeding 20\% among youths aged 20-24 are found only in a handful of OECD member countries, including France and the countries of Southern Europe (Figure 25, Panels A and B). This high rate is not an artefact of a greater propensity to study, which would reduce the labour force in the denominator of the unemployment rate, given that, at approximately $40 \%$, the proportion of the 20-24 cohort pursuing studies is relatively small, well below that observed in the countries of Northern and Eastern Europe and Germany (Figure 25, Panel C). The employment rate is low for this age group (slightly below 50\%, Figure 25, Panel D), combining studies and work is uncommon, and approximately $20 \%$ of French youths aged 20-24 are NEET and thus structurally at risk of social marginalisation (Figure 1).

15. Historically, the degree was designed as a diploma for the acquisition of knowledge and not for vocational training (Cour des comptes, 2012). The vocational degree, introduced in 1999 in partnership with industry, is a one-year diploma course open to students who have successfully attained the level of the baccaluareat + two years of higher education. The course is designed to allow young people to enter into employment, and includes 12 to 16 weeks of work placement and completion of a project under the supervision of a tutor. 
Figure 25. Youth labour market indicators
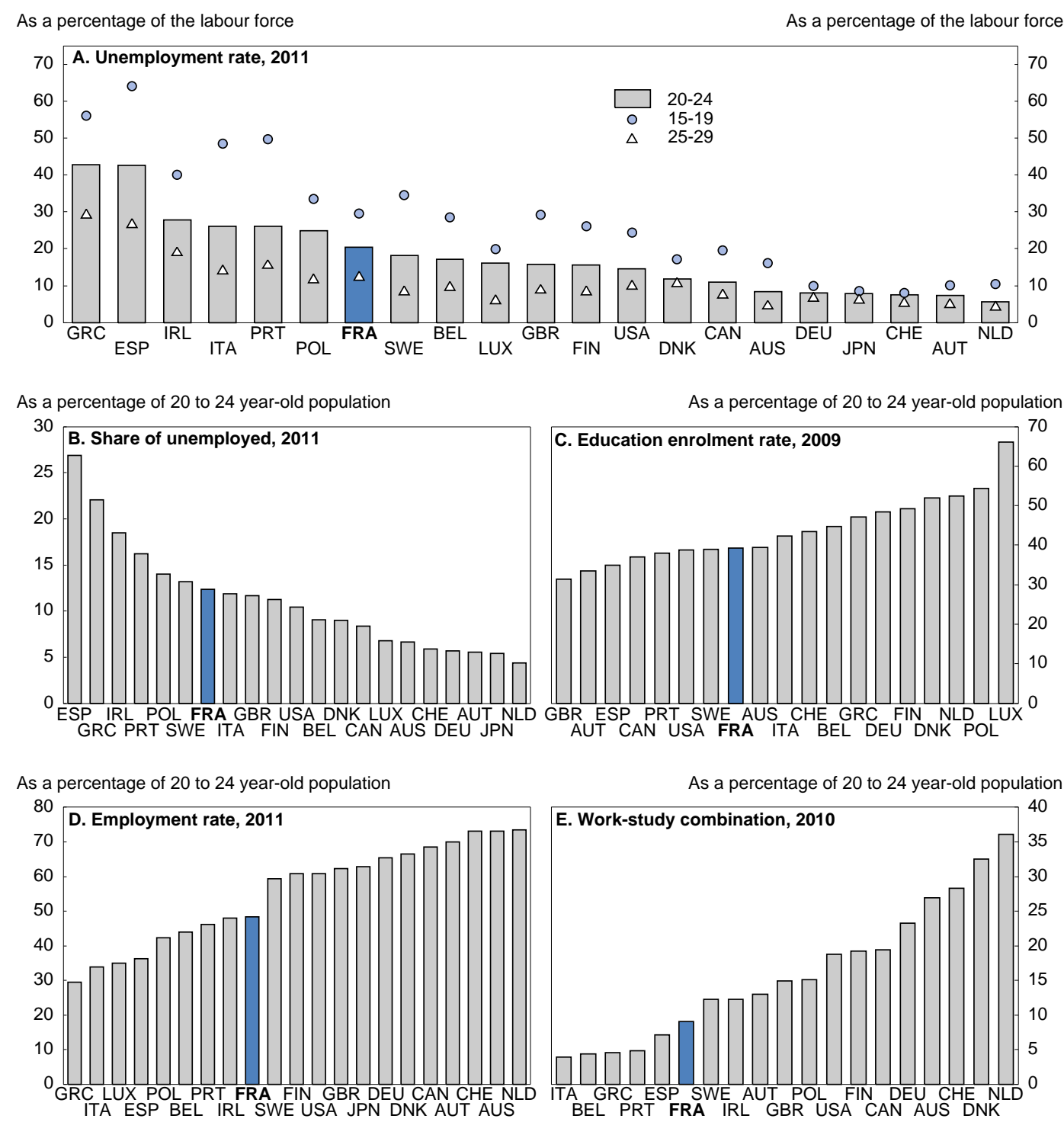

Source: OECD, Labour Force Statistics 2012 and Education 2012 databases.

Comparing with the Netherlands, Denmark and Germany, which report strong performance on the youth labour market, reveals that more French youths aged 20-24 are NEET (by approximately 10 percentage points) and experience great difficulties in the school-to-work transition: fewer of them are in school (approximately 10 points), far fewer are working (10 to 30 points), far fewer are combining work and studies (15 to 25 points, Figure 25, Panel E) and thus more are studying without working (5 to 15 points). The 15-29 age group accounts for over half of the total unemployment rate differential with countries that could serve as a reference (Figure 26), though their share in the labour force is only $22 \%$ (see Boulhol and Sicari, 2013b for more details). 
ECO/WKP(2013)33

Figure 26. Explaining the gap between the unemployment rate in France versus other OECD members

Structural-residual analysis in percentage points, by age group

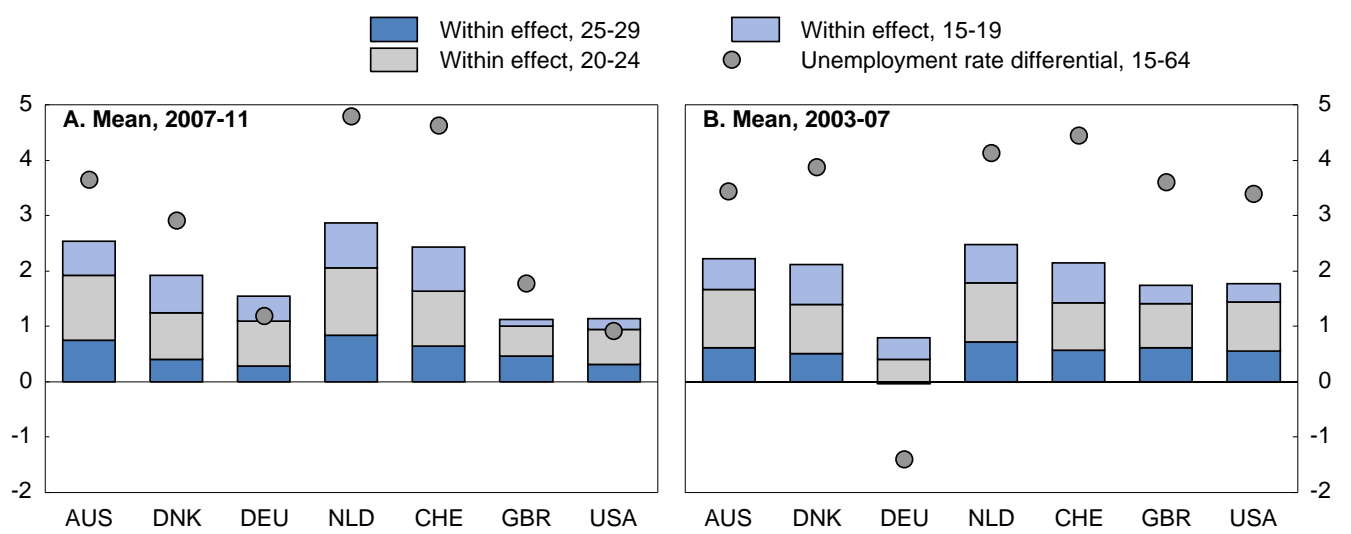

Source: Boulhol and Sicari (2013b).

How to read this figure: On average over 2007-11, France's unemployment rate was 3.7 percentage points higher than Australia's. The "within" component was equal to 4.8 points. for this pair of countries, of which the 15-19, the 20-24 and the 25-29 age groups contributed $0.6,1.2$ and 0.7 points, respectively.

Examining the age-based structure of employment rates shows that the low employment rate of 20-24 year olds improves rapidly, reaching a relatively high level of approximately $80 \%$ for the $30-34$ age group, a stable feature in recent decades. However, this does not mean that the age 20-24 NEET cohort eventually transitions into the labour force successfully. Rather, the increase in employment rates is primarily reflects a structural effect, as the most educated enter the labour market later (Batard and Saillard, 2011), especially in France where combining work and studies remains less common. In a highly stylised representation, the 30 percentage point difference between the employment rate of the 25-29 and the 20-24 cohorts corresponds to the proportion of 20-24 year-olds who are studying and not working. Conversely, NEETs account for one fifth of both the 25-29 and the 20-24 cohort (Figure 1). As in Belgium, but more than in Spain, Italy and Poland, which also report low youth employment rates, the employment rates of 35-39 year olds are similar to those of Northern Europe, Switzerland and Austria (Figure 27, and Boulhol and Sicari, 2013b). Overall, France is the OECD country with the largest employment-rate differentials across age groups.

\section{Simultaneously acting on labour demand and supply}

Youths are affected by difficulties weighing on the labour market generally, and their average unemployment rate relative to that of the 25-54 age group is consistent with its value in other countries (Figure 28). This overall weakness (resulting from a tax structure that is inimical to job creation, inefficient public spending, an unproductive social dialogue, cumbersome regulations facing some professions, etc.) is analysed in the Assessment and Recommendations. Other factors primarily affect youths, through effects on either demand (job protection, minimum wage, subsidised contracts) or supply (job-search support, educational system). However, the current public support for youths (scant access to revenu de solidarité active, or RSA; the short actual duration of unemployment benefits) is unlikely to reduce their labour supply to any great extent, in contrast to what happens more generally (Égert , 2013). 
Figure 27. Employment rate by age bracket, ranked classification ${ }^{1}$

2005-2011 mean, as a percentage of the population by age bracket

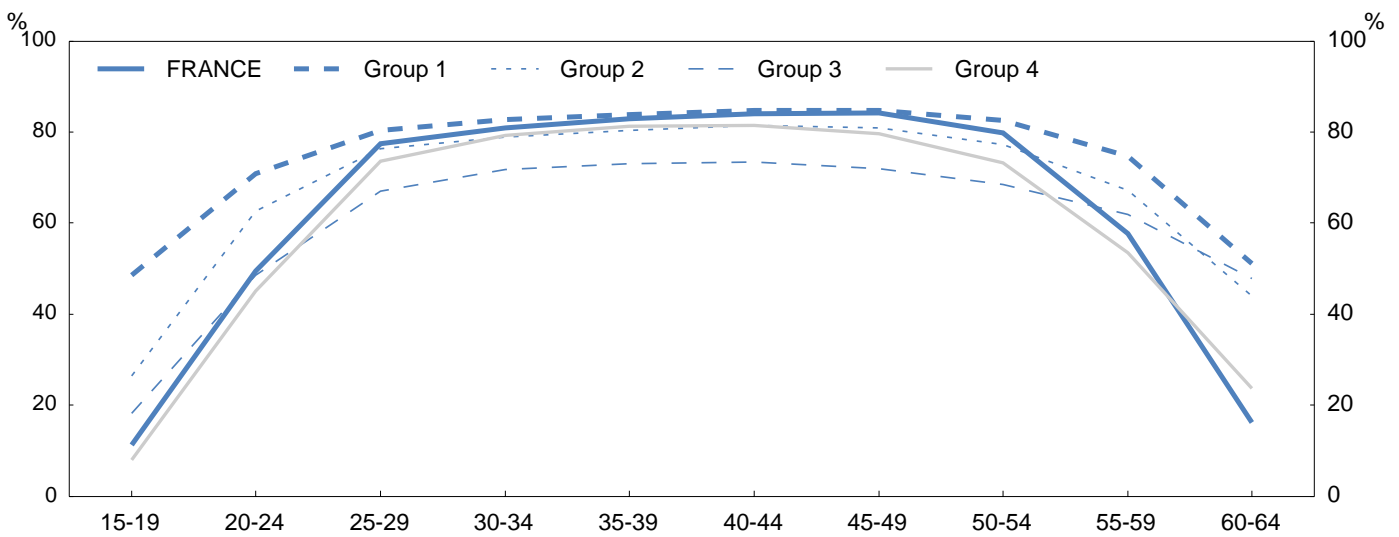

1. A ranked classification was used to identify groups of OECD countries by the structure of employment rates by cohort. Group 1 includes: Australia, Canada, the United Kingdom, Denmark, the Netherlands, Iceland, New Zealand, Norway and Switzerland. Group 2 includes: Austria, Finland, Germany, Japan, Sweden, Ireland, the United States and Mexico. Group 3 includes: Chili, Israel and Korea. Group 4 includes: Belgium, Luxembourg, Poland, Slovenia, Greece, Spain, Hungary, Italy, Slovakia, the Czech Republic, France, Estonia and Portugal. The composition of these groups varies with the period. For example, considering only the pre-crisis period (2005-07), Austria, the United States and Sweden were in Group 1, Estonia and Portugal in Group 2, and Mexico in Group 4.

Source: Boulhol and Sicari (2013b).

Figure 28. The difficulties confronting youths reflect a broader problem with the labour market

Mean 2000-2011

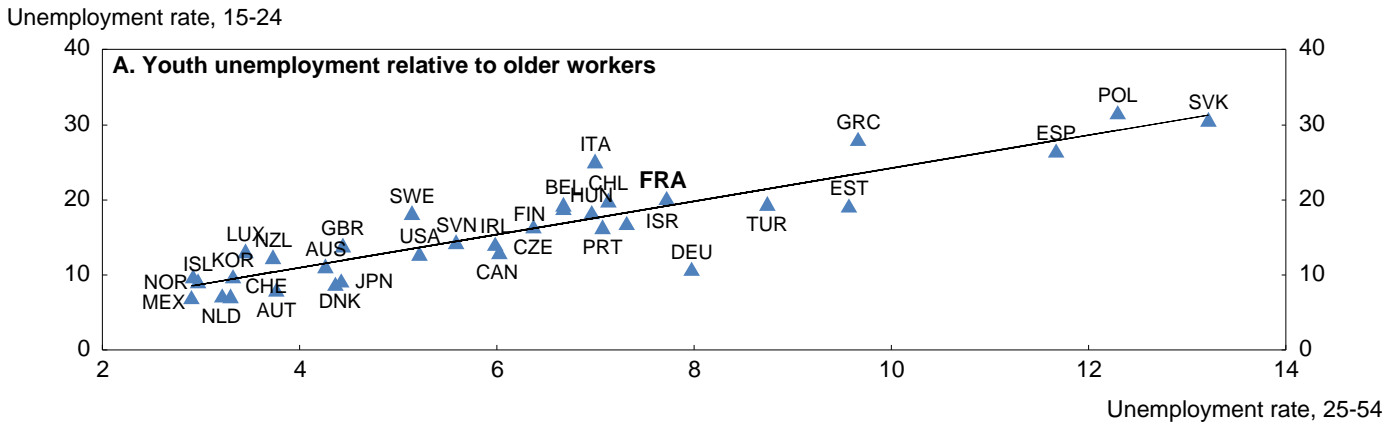

Employment rate, 15-24

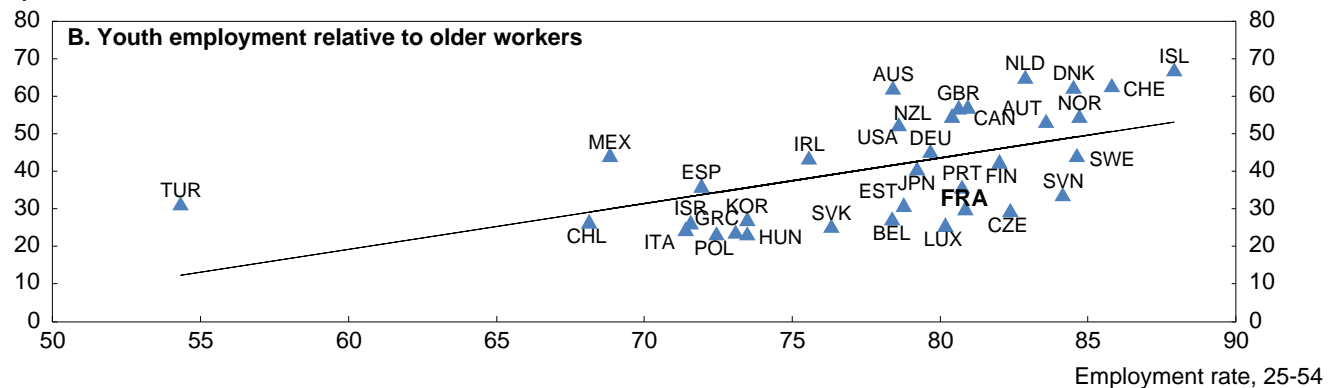

Source: OECD, Labour Force Statistics 2012 database. 


\section{The duality of labour contracts penalises youths}

The French labour market is sharply segmented, employees with permanent contracts benefiting from strong employment protection. This system may be detrimental to the job prospects of new entrants by protecting workers with seniority. On the other hand, however, the low cost of dismissing young employees (especially when they have temporary contracts, which is often the case in France) does not create a barrier to hiring. Thus, protection has an impact on youth employment that is theoretically ambiguous. Empirically, Bassanini and Duval (2006) find that employment protection significantly reduces youth employment in OECD countries.

Nonetheless, a segmented labour market unambiguously causes the adjustments required to absorb shocks to fall disproportionately on those who are vulnerable, primarily youths, and especially the unskilled. France, along with Spain and Belgium, seems to be one of the OECD countries in which the sensitivity of youth unemployment to the business cycle is greatest (in absolute terms and relative to all ages combined): after one year, a one point GDP shock translates into an estimated increase of over 1 point in the unemployment rate of 15-24 year-olds, versus an average of 0.6 for the OECD and 0.3 in France for the age 25-54 cohort (Figure 29 and Boulhol and Sicari, 2013b).

Figure 29. Sensitivity of the youth unemployment rate to economic fluctuations, 15-24 years

Estimated unemployment rate variation one year after a one-point negative GDP shock

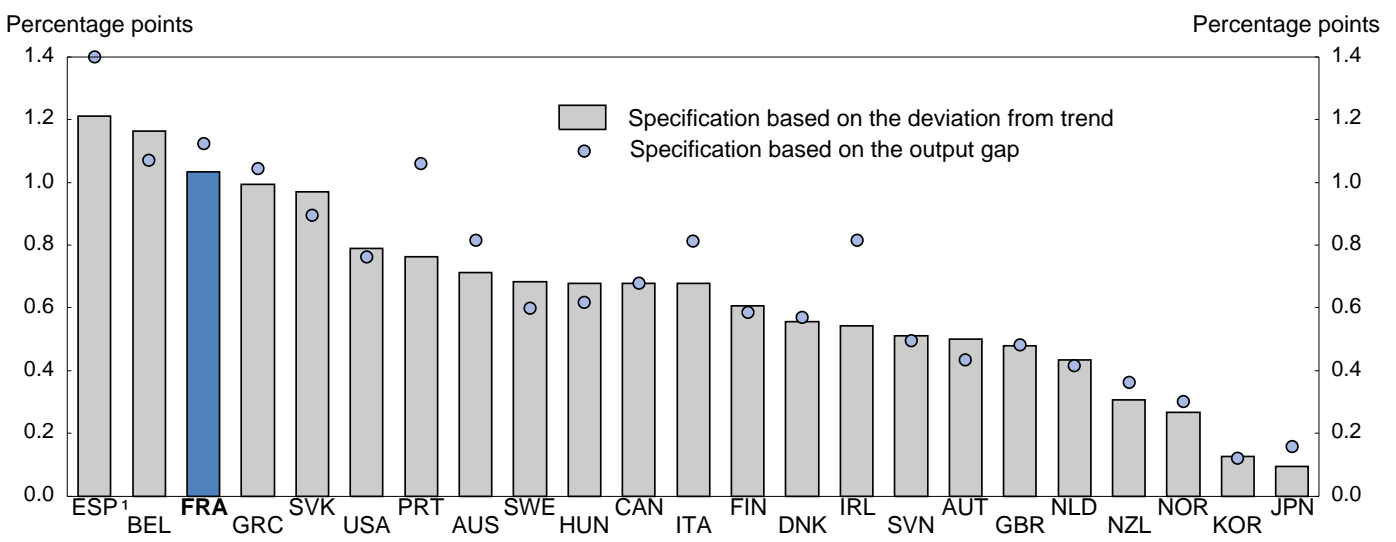

1. For the specification based on the output gap, the change in the youth unemployment rate has been capped to 1.4 to improve the readability of the graph, the true value being 2.4 .

Source: Boulhol and Sicari (2013b).

Yet without question young people's efforts to integrate into the labour market through stable contracts are stymied in countries with a dual labour market. Quintini and Martin (2006) find a significant positive correlation between job protection and the length of time it takes to obtain a first job, Austria and Germany faring better thanks to apprenticeships. Furthermore, the school-to-work transition is more arduous in countries in which studies and work are rarely combined (OECD, 2009). In France, as in the countries of Southern Europe, an underdeveloped system of connections to business coexists with labour market rigidities (job protection, minimum wage). Consequently, the school-to-work transition is drawn out.

A number of indicators reveal that this duality is very detrimental to French youths. Among those aged 15 to $29,34 \%$ of jobs are temporary, versus $13 \%$ for the working population as a whole (DARES, 2012). Temporary work is also much more prevalent for youths than in most OECD countries (Figure 30). In France it is increasingly rare for these contracts to serve as a springboard to stable 
employment: between 1996 and 2006, the probability of having a permanent contract within one year of having a fixed-term contract fell from $43 \%$ to $18 \%$ for $15-24$ year olds (OECD, 2009). According to the EU-SILC panel, only $14 \%$ of all employees with temporary contracts have a permanent contract one year later. This is the lowest rate in all of Europe (Table 3). Other sources cite slightly higher transition rates, however: for instance, based on the employment survey, it has been estimated that $8 \%$ of workers on temporary contracts end up on permanent contracts three months down the road (DARES, 2012a). Since the beginning of the 1980s, interruptions in employment have also become more commonplace among youths (Cordelier, 2006). These erratic career paths may result in underinvestment in human capital by both employers and youths. The national inter-industry agreement of 11 January 2013 (see Assessment and Recommendations) provides a three-month exemption from employer-paid unemployment insurance premiums (i.e. 4 percentage points) for any hiring on a permanent contract of a youth under age 26 .

This agreement constitutes an important first step that can give businesses more flexibility (see Assessment and Recommendations). To further reduce duality, the definition of "economic dismissals" should be expanded, employer redeployment obligations reduced and dismissal procedures simplified. Regarding economic dismissal, one of the major objectives would be to limit the courts' authority to assess intent. In Australia, for example, economic dismissal is deemed to have a real and serious cause if it follows the elimination of a job that does not mask a personal motivation. This easing could be combined with higher employer payroll taxes on temporary contracts and with effective limits on abusive use thereof (as in Finland and Norway). Finally, the probationary period could be extended to provide employers with an incentive to more readily offer permanent contracts to newcomers (Figure 31). In Denmark, in particular, the length of the probationary period is an integral part of the "flexicurity" strategy (OECD, 2009).

Figure 30. Youth temporary work, 2000-11 ${ }^{1}$

Temporary jobs as a percentage of total employment of youths aged 15-24

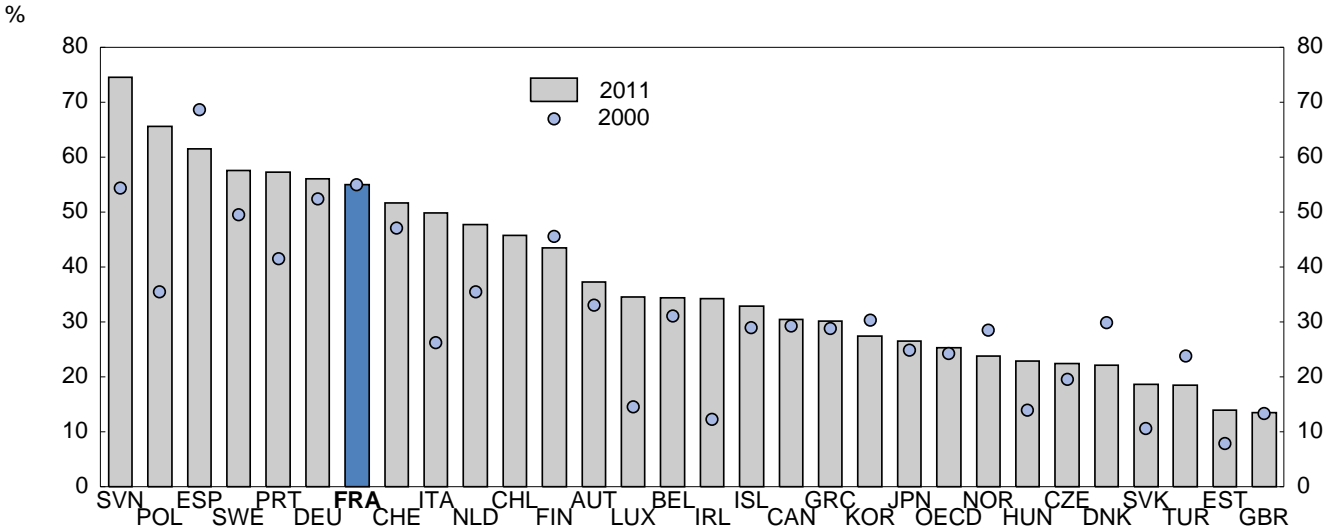

1. 2000 data replaced with 2001 data for Poland; 2002 for Slovenia and Estonia; 2004 for Korea.

Source: OECD, Labour Force Statistics 2012 database. 
Table 3. Mobility of temporary workers in one year

\begin{tabular}{|c|c|c|c|c|}
\hline & \multicolumn{4}{|c|}{ Temporary workers on path to: } \\
\hline & $\begin{array}{l}\text { permanent } \\
\text { work }\end{array}$ & unemployment & $\begin{array}{c}\text { temporary } \\
\text { work }\end{array}$ & other ${ }^{1}$ \\
\hline Slovak Republic & 52.4 & 6.1 & 32.6 & 9.0 \\
\hline Hungary & 46.9 & 11.0 & 25.0 & 17.0 \\
\hline United Kingdom & 45.1 & 2.5 & 28.9 & 23.5 \\
\hline Norway & 43.5 & 4.9 & 36.7 & 14.9 \\
\hline Austria & 41.6 & 5.6 & 30.8 & 21.9 \\
\hline Sweden & 41.2 & 10.4 & 36.3 & 12.0 \\
\hline Luxembourg & 40.1 & 10.4 & 40.7 & 8.7 \\
\hline Slovenia & 38.8 & 9.6 & 43.3 & 8.3 \\
\hline Ireland & 38.1 & 7.4 & 35.3 & 19.2 \\
\hline Czech Republic & 37.3 & 5.0 & 48.3 & 9.4 \\
\hline Belgium & 35.8 & 8.4 & 42.8 & 12.9 \\
\hline Italy & 29.7 & 8.1 & 47.0 & 15.2 \\
\hline Poland & 26.9 & 8.9 & 54.7 & 9.5 \\
\hline Iceland & 24.7 & 2.6 & 38.2 & 34.5 \\
\hline Germany & 23.0 & 0.7 & 53.9 & 22.4 \\
\hline Netherlands & 22.9 & 1.6 & 65.5 & 10.0 \\
\hline Spain & 22.6 & 14.0 & 49.4 & 13.9 \\
\hline Greece & 21.4 & 9.1 & 59.1 & 10.3 \\
\hline Portugal & 21.0 & 11.4 & 57.0 & 10.7 \\
\hline Finland & 20.3 & 9.9 & 48.0 & 21.8 \\
\hline France $^{2}$ & 13.8 & 9.2 & 71.6 & 5.4 \\
\hline Mean & 29.0 & 9.1 & 49.5 & 12.4 \\
\hline
\end{tabular}

Note: Probability of transition from a temporary job within one year, between 2003 and 2009. For example, the probability of moving from a temporary job to a permanent job is computed as follows: number of persons occupying a temporary job within a given year and a permanent job one year later, divided by the total number of transitions.

1. Including self-employed persons, students and other inactive categories.

2. According to INSEE, based on data from Labour Force Surveys, the rate of transition from temporary to permanent employment after one year - over the same period - was $15.8 \%$. This is anyway an underestimate, as $26.6 \%$ of employees with temporary contracts are not observed one year later.

Source: Longitudinal EU-SILC data and OECD calculations.

Figure 31 . Length of the probationary period, $2008^{1}$

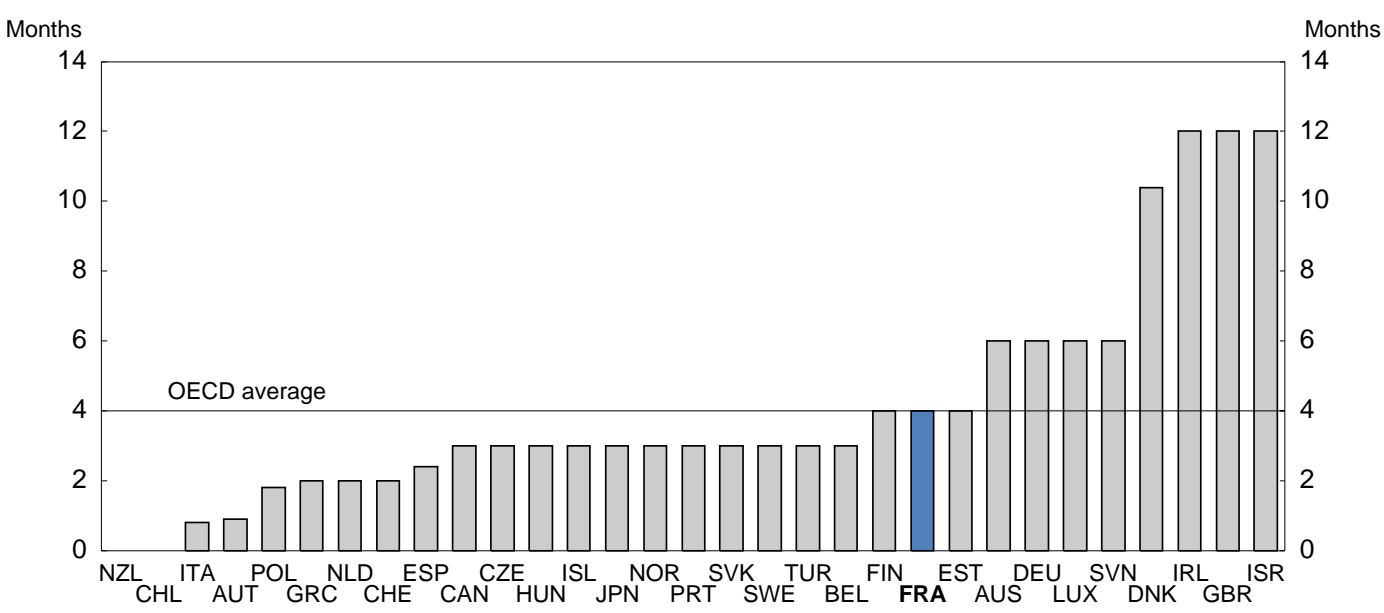

1. 2009 for France and Portugal.

Source: D. Venn (2009), "Legislation, Collective Bargaining and Enforcement: Updating the OECD Employment Protection Indicators", OECD Social, Employment and Migration Working Papers, No. 89. 


\section{The level of the minimum wage tends to exclude unskilled youths from employment}

Approximately $30 \%$ of employees under 25 are paid the minimum wage (salaire minimum interprofessionnel de croissance, or SMIC), versus 11\% for all employees (and an OECD average of 5\%). Despite an easing of the payroll tax burden on low-wage earners, the cost of labour at the minimum wage is relatively high in relation to its cost at the median wage, and close to the average for OECD countries that have a legal minimum wage (see Figure 21 in the Assessment and Recommendations section). The demand for labour is particularly sensitive to cost in terms of the minimum wage for youths and low-skill workers. Moreover, in light of its effects in terms of involuntary part-time work and unemployment, especially for these two population groups, the minimum wage is inefficient for reducing overall income inequality and poverty, even if it allows earnings inequalities among full-time workers to be contained.

Many OECD countries have adopted a lower minimum wage for youths (Figure 32). In particular, Australia and the Netherlands, which also have high minimum wages, have introduced broad exemptions for them. In France, the regulation allows only a 10\% abatement for youths under 17 having less than six months experience, and 20\% for those less than 16. Compared to other countries, relative wages in France are high for youths and seniors, categories with depressed employment rates (Figure 33). Thus, in France more than elsewhere, (unskilled) youths find themselves competing with experienced adults without the benefit of a cost advantage. This also gives rise to an inefficient reliance on internships designed to subvert the minimum-wage provisions. An age-related lower minimum wage for youths could be considered in conjunction with measures designed to reduce duality (higher payroll taxes on temporary contracts, extension of the probationary period of indefinite-term contracts) and the progressive extension of the RSA to youths under certain conditions. Different arrangements could be tested in regions suffering from varying degrees of youth unemployment.

Figure 32. Minimum wage and age, $2010^{1}$

As a percentage of median wage

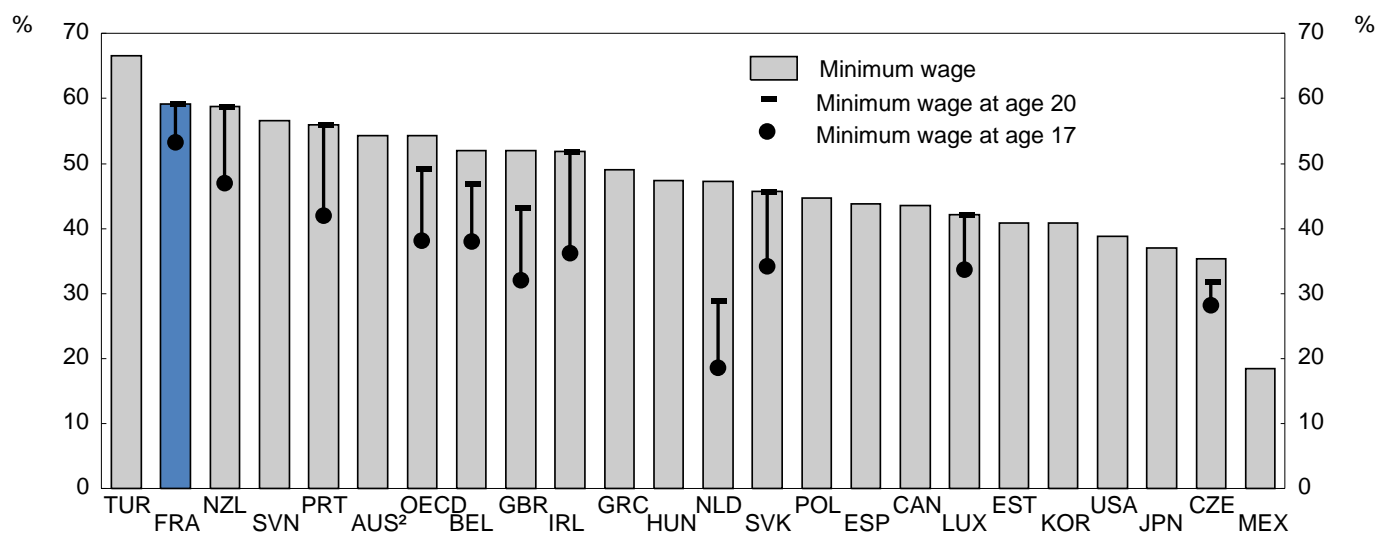

1. Gross amount excluding potential payroll tax reductions.

2. Young Australians can benefit from a reduced minimum wage thanks to their collective agreements. In July 2012 Australian authorities introduced a minimum wage of $58 \%$ and $98 \%$ of the regular minimum wage for youths aged 17 and 20 years, respectively, applicable to youths and apprentices excluded from collective agreements.

Source: OECD, OECD Minimum Wage database 2012. 
Figure 33. Distribution of mean wages by age bracket, 2009

Full-time employees, mean wage for all ages $=100$
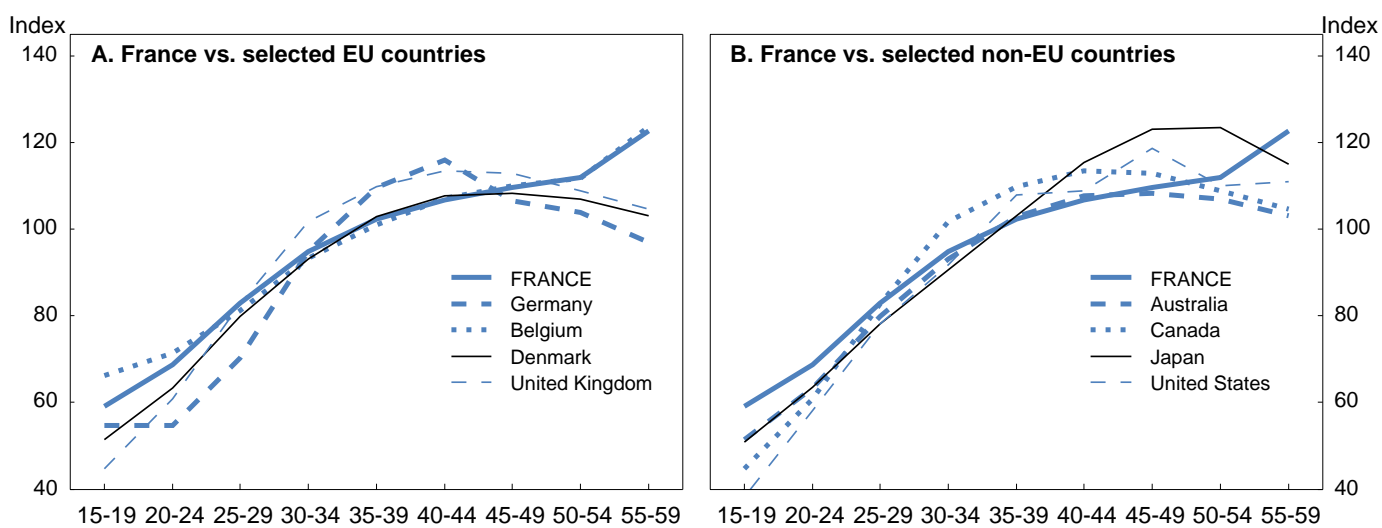

Note: These figures should be interpreted cautiously since they may reflect composition effects, for example if the lowest-skilled workers leave the labour market earlier in France. Endeavouring to correct endogeneity biases, Aubert and Crépon (2004) showed, however, that in France there was a decoupling of productivity from wages as from age 50, even if the estimations may lack precision (Aubert, P. and B. Crépon, 2004, "Age, salaire et productivité: la productivité des salariés décline-t-elle en fin de carrière?" in Economie et Statistique).

Source: OECD, Wages and Earnings database.

In 2013 the government is implementing "generational contracts". This new provision consists of granting a lump-sum subsidy to businesses with fewer than 300 employees that sign a permanent contract with a youth aged below 26 while retaining a senior aged over 57 . The amount of the subsidy is equal to EUR 2000 annually for the young worker and EUR 2000 for the senior. Businesses with 300 or more employees, which do not qualify for these subsidies, will need to sign agreements or institute age management action plans aiming to promote both the hiring of young people on permanent contracts and keeping seniors on the job. According to the government, this measure also meets the challenge posed by the transmission of know-how and abilities with a view to the massive retirement of baby boom cohorts.

While the provision does not specifically target the least qualified, the subsidy decreases with earnings in percentage because it is a lump sum. This type of measure is, however, like most for-profitsector hiring subsidies, vulnerable to potentially substantial deadweight losses and substitution effects. Allègre et al. (2012) estimate on the basis of a similar measure that, for every 500000 contracts signed, fewer than 100000 permanent net positions will be created. The 300 -employee threshold will, however, allow these losses to be mitigated. This measure can cut the cost of employing young people and seniors, although that is not the government's primary stated objective for it. However, it would be better to directly address the negative impacts of how wages are set for these groups of workers to avoid the depletion of government coffers. Low employment rates of youths and seniors are likely to have shared causes, linked, for example, to the poor functioning of the labour market overall (Figure 4).

\section{Subsidised work contracts: promoting a work-study approach for the least skilled}

Assisted work contracts (including apprenticeships), which are heavily subsidised (up to $90 \%$ of the minimum wage for the non-market sector), ${ }^{16}$ are primarily targeted at youths under 26 years of age ( $70 \%$,

16. Moreover, subsidies to assisted contracts in the non-profit sector amount to $90 \%$ of the minimum wage. Apprenticeship incentives include a tax credit for companies, payroll and income tax exemptions, wage subsidies and paying for the training. They were extended until June of 2012 to cushion flagging economic growth. Under these provisions, the apprentice's wage is computed on the basis of age and seniority, 
approximately). They represent about one-quarter of the jobs occupied by youths - down from the peak of nearly one-third in 1997-98 but up significantly from the 5 to $10 \%$ levels that prevailed prior to their widespread adoption during the mid-1980s (Figure 34). Approximately 50\% of youths without a secondary school diploma are on subsidised contracts (DARES, 2011) ${ }^{17}$ In response to the ongoing crisis, the authorities boosted the share of non-profit organisations in subsidised jobs from $4 \%$ in 2008 to $10 \%$ in 2010, and it will probably exceed 20\% in 2013. During the second quarter of 2012 the government created 80000 subsidised jobs, primarily in the non-profit sector, and it intends to create 100000 "jobs for the future" (emplois d'avenir) in 2013 (and 50000 more in 2014) targeted at the least skilled workers and the non-profit sector, and including a training component, for a total budgetary cost of EUR 2.3 billion in 2013.

Figure 34. Share of assisted jobs in the employment of youths under 26

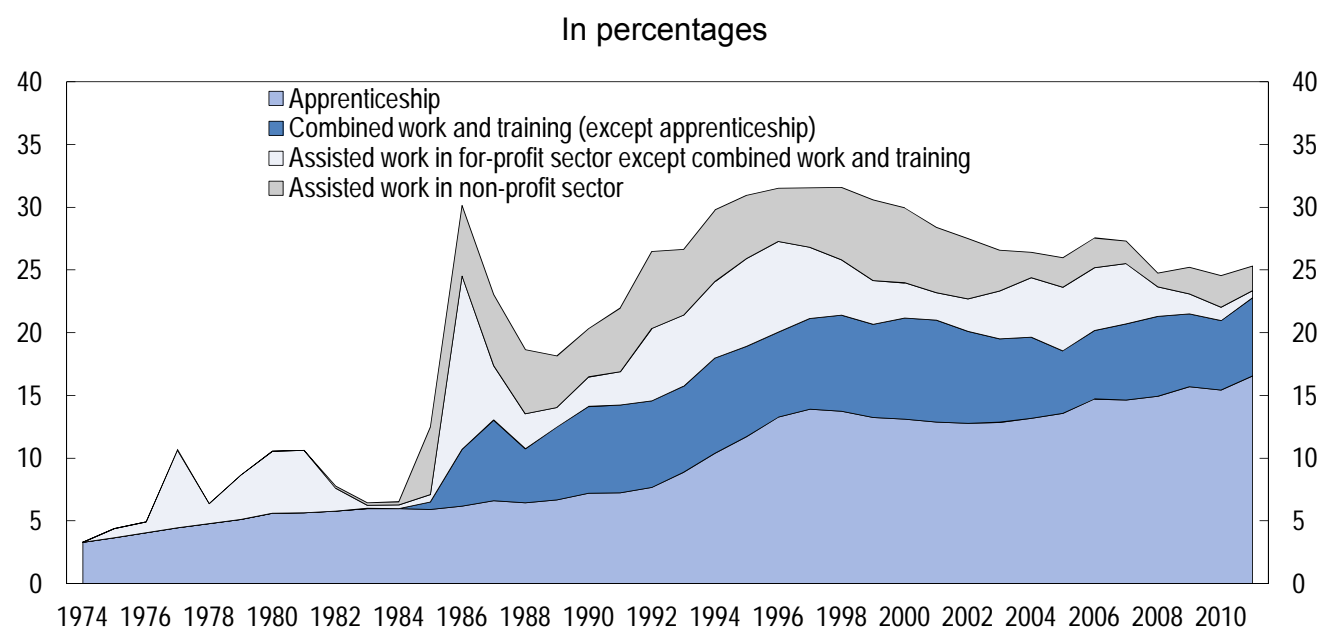

Source: DARES, mesures pour l'emploi; INSEE, Employment surveys.

In France, approximately one youth in two attending upper secondary school is in a vocational programme - this ratio is close to the OECD average (Figure 35). As in Norway and the Netherlands, for example, vocational training is delivered either purely by academic programmes or by apprenticeship. Other countries, including Germany, Austria, Denmark, Ireland and Switzerland, have almost exclusively

ranging between 25 and $78 \%$ of the minimum wage (Sanchez, 2011). Furthermore, companies with more than 250 employees must meet a mandatory quota of employees in combined work and training or pay a penalty in the form of an apprenticeship tax set at $0.2 \%$ of the payroll $(0.3 \%$ for companies with over 2000 employees). This quota was raised from 3 to $4 \%$ in July of 2011 to help reach the goal set by the previous government of 800,000 youths in combined work and training by 2015 . In 2010 , businesses with over 250 employees only employed $13 \%$ of apprentices (while accounting for approximately $40 \%$ of private-sector employees) and those with fewer than 50 employees had $80 \%$ of apprenticeships (and $45 \%$ of employees) (Sanchez, 2011). Revenues from the apprenticeship tax represented approximately $€ 2$ bn in 2011, only about half of which went to financing vocational training centres (Centre de formation d'Apprentis, CFA). In total, between 2008 and 2012, the annual cost of subsidized contracts for youths amounts to approximately $€ 8$ bn ( 0.4 GDP points), of which approximately $85 \%$ for combined work and training.

17. These are non-profit sector contracts (approximately 50,000 in 2011), for-profit sector contracts with, and without $(15,000)$, a combined work and training component, including apprenticeship contracts $(435,000)$ and on-the-job training contracts (contrats de professionnalisation) $(165,000)$. These latter allow youths to up-skill after leaving school. 
opted for the apprenticeship path. By means of comparison, apprenticeship often permits a more fluid

Figure 35. Enrolment in upper secondary education, 2009

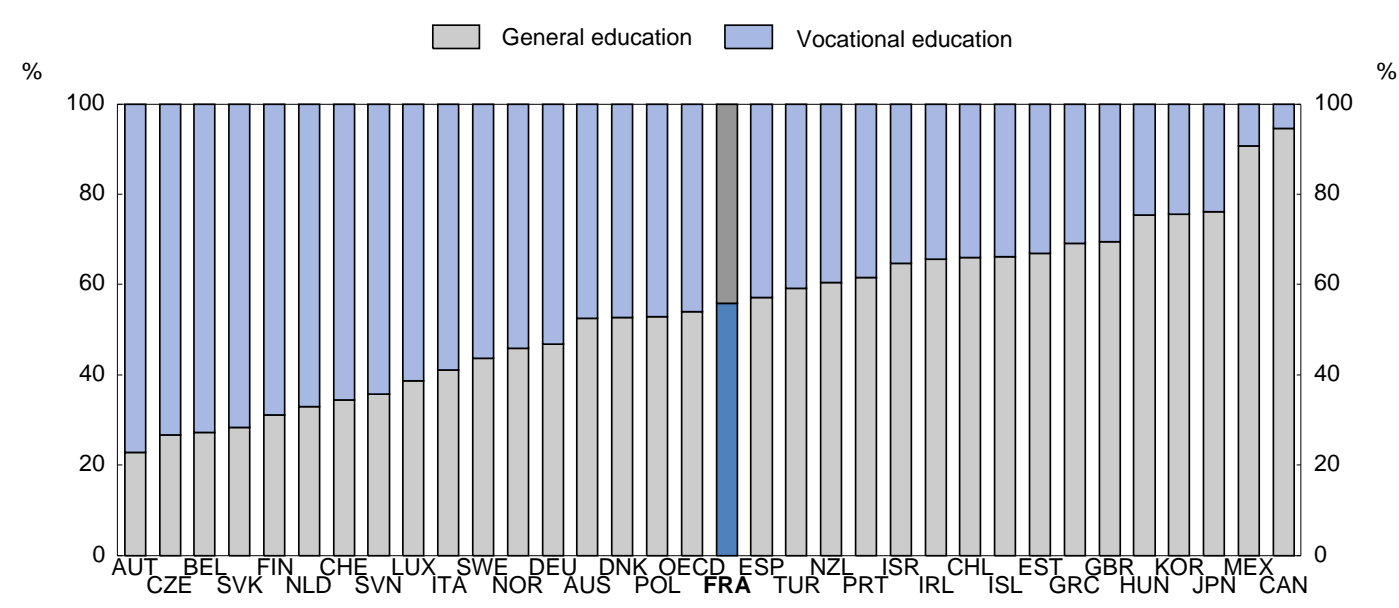

Source: OECD (2012), Equity and Quality in Education.

transition to employment, but it provides more specialised qualifications that may limit the worker's ability to adapt to technological change (Quintini et al., 2007). Most French vocational training centres (CFAs) are managed by local chambers of commerce and industry or chambers of trades and crafts. According to the Cour des comptes (2008), these two streams of vocational training are juxtaposed with no real co-ordination between the CFAs and the Ministry of Education. In Norway and the Netherlands, on the other hand, close co-operation between these two streams allows the right training to be found immediately for students unable to find an apprenticeship, which plays a useful countercyclical role (OECD, 2009). No real assessment has been conducted of the operations of CFAs.

Studies of the impacts of subsidised employment conducted since the 1980s have yielded a certain consensus (Fougère et al., 2000; OECD, 2008 (Box 4.1); Aeberhardt et al., 2011). First, assistance to non-profit employment may provide a rapid countercyclical response, but it does not have a lasting impact on the school-to-work transition. Second, a high training content promotes labour market integration: this is the case for combined work and training contracts. Third, all other things equal, relative to professional training that is purely academic, apprenticeship provides a seven-percentage point edge in terms of employment rates in the short term, and slightly higher earnings (Abriac et al., 2009). From this perspective, the upward trend in the apprenticeship share of these subsidised arrangements is welcome.

Despite the substantial subsidies, many youths cannot find a company for their apprenticeship, while many others drop out of the programme. One way to improve both incentives to take training and its attractiveness to business might be to make a non-negligible share of the apprentice's salary contingent on results. In addition to its institutional organisation, which is not readily reproducible, one of the keys to Germany's successful apprenticeship programme has been the quality of social dialogue (Quintini et al., 2007), in particular with regards to the flexibility of the apprenticeship schemes. Constructive social dialogue would help in attaining a better balance in France in areas extending far beyond the issue of apprenticeship (Cahuc and Zylberbeg, 2009; OECD, 2011b, Figure 36). 
Figure 36. Labour-management relations do not seem to be of good quality
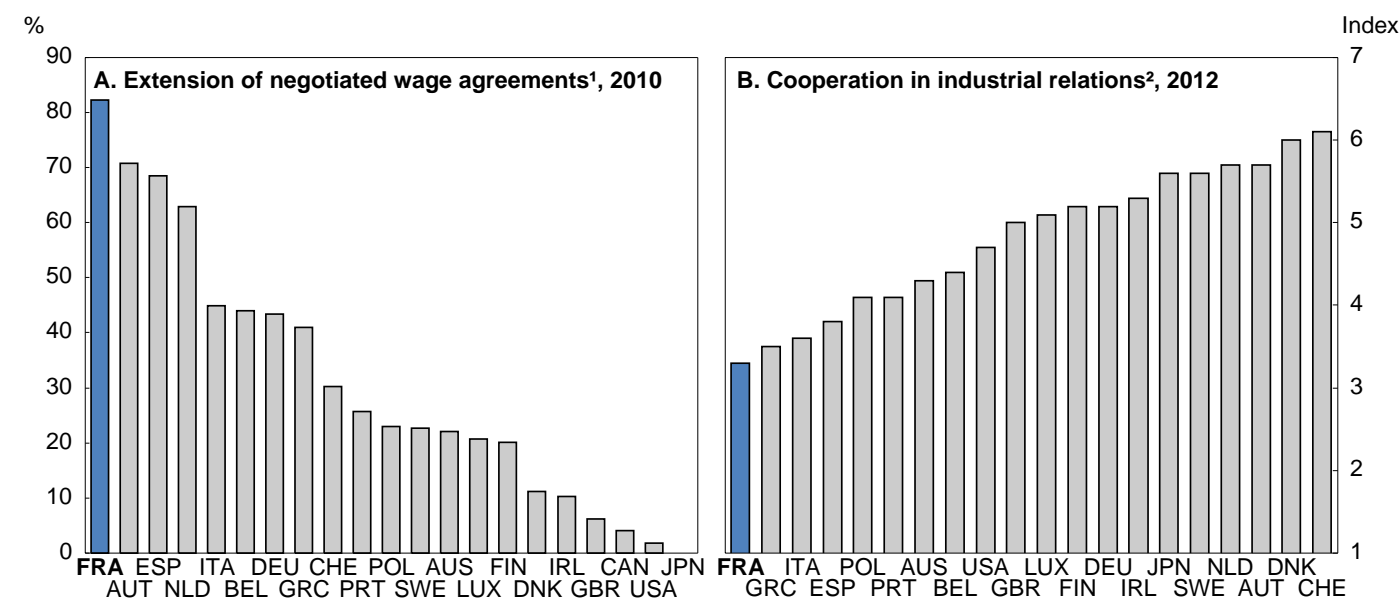

1. Arithmetic difference between the rate of coverage of collective agreements and the unionisation rate.

2. Index ranging from 1 to 7 , based on a question posed to 14000 business leaders (of which 129 in France), with 7 indicating the greatest possible level of co-operation.

Source: OECD, Going for Growth 2012; World Economic Forum, Global Competitiveness Report 2012-2013.

In addition, in France the trend in apprenticeships has been to offer contracts to apprentices with increasingly higher levels of education (Abriac et al., 2009), which tends to marginalise the youths who experience the greatest difficulties finding work. While the number of apprentices has nearly doubled in the past 20 years, that of the least skilled has remained stable (Figure 37).$^{18}$ Deadweight losses in the

Figure 37. Number of apprentices at year end by level of diploma ${ }^{1}$

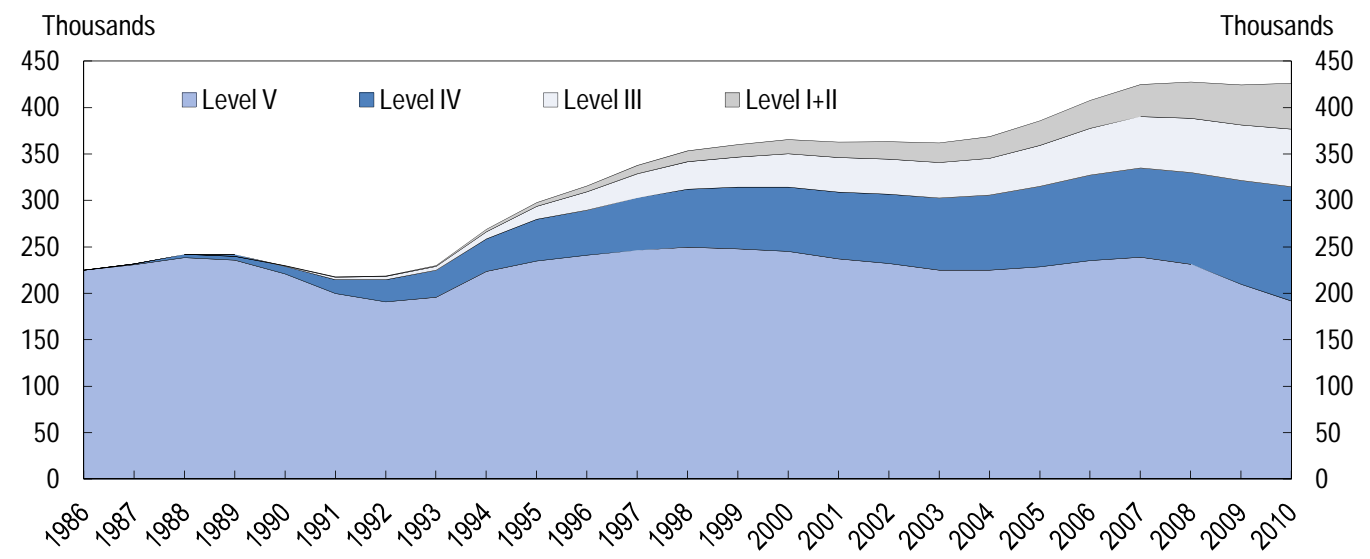

1. Certificat d'aptitude professionnelle (CAP), brevet d'études professionnelles (BEP) with additional module (MC) for level V; brevet professionnel (BP), professional baccalaureat (Bac pro) with additional module (MC) for level IV; brevet de technicien supérieur (BTS), diplôme universitaire de technologie (DUT) for level III; bachelor's degree, master's degree for level II; engineering diploma, diploma in specialised higher studies (DESS), master's degree for level I.

Source: Ministry of Education, DEPP.

18. The structure of on-the-job training contracts is even more biased in favour of those with skills: In 2011, $25 \%$ of contracts were held by the least skilled, $39 \%$ by those with a secondary school diploma, $36 \%$ by those with a higher education (Sanchez, 2012). 
for-profit sector are quite large when programmes are not targeted at those furthest from employment (Martin and Grubb, 2001). Thus, it is important to prevent combined work and training contracts from simply being used to reduce labour costs and to clearly differentiate between types of assistance based on the skill level. Furthermore, for students in vocational upper-secondary schools, apprenticeship becomes a complement to professional training, rather than the substitute it was meant to be: this duplication draws out the process and is inefficient and costly for the public purse.

\section{Combating ethnic discrimination on the job market}

Relative to other countries of the OECD, in France children of immigrants make up a relatively small proportion of youths aged 20-29, in particular owing to the limited flows of young immigrants (Table 4).

Table 4. Share of children of immigrants not in education among those aged 20-29, around 2007

Per cent

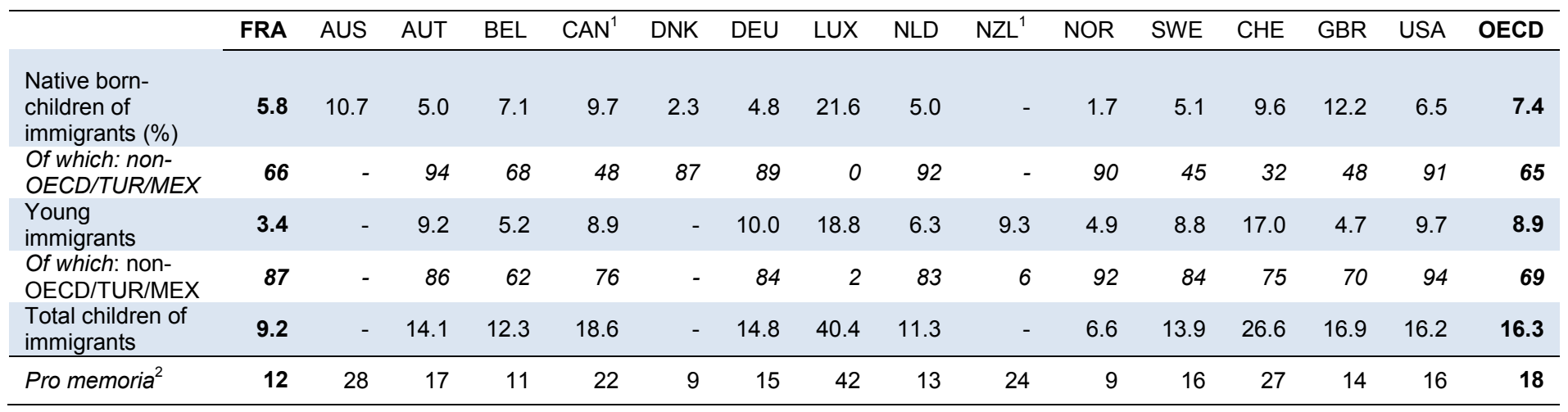

1. Data for Canada refer to the 2006 census and for New Zealand to the percentage of the foreign-born labour force from the 2006 census.

2. Share of foreign-born in total population aged $15-64(2008, \%)$.

Source: OECD (2010), Equal Opportunities? The labour market performance of children of immigrants.

The differential between the unemployment rates of children of immigrants and children of the native born is large, as in most European countries aside from the United Kingdom and Switzerland, but it is smaller than in Belgium and the Netherlands (Figure 38).

Figure 38. Gap between unemployment rates of children of immigrants and native-born aged 20-29, 2007

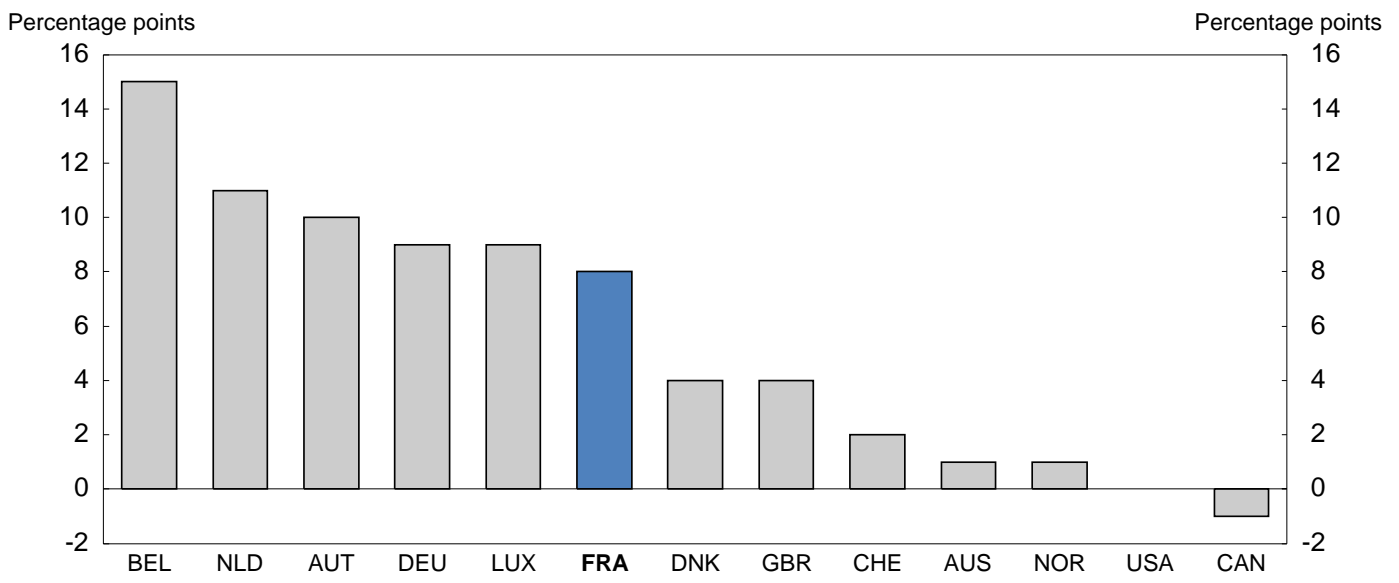

Source: OECD (2010), Equal Opportunities? The labour market performance of children of immigrants. 
It is now well documented that in France individuals of foreign origin suffer widespread discrimination by employers and that youths are particularly affected (Cédiey and Foroni, 2007 and 2008; OECD, 2008a and 2008b). Differences between the education levels of the children of immigrants and those of the native-born account for less than one-third of the employment rate differential for 20-29 year-olds (OECD, 2010). For the population as a whole, individual characteristics explain only 4 of the 18 percentage point differential between the employment rates of French with at least one immigrant parent from the Maghreb and those with both parents born in France (Aeberhardt et al., 2010a). Conversely, they fully explain earnings gaps (13\%). The essential difference in treatment penalising youths with origins in the Maghreb or sub-Saharan Africa is apparent even before they have a job interview children of African immigrants need to apply three to fifteen times as often as French candidates with identical profiles to get their foot in the door (OECD, 2008b).

Combating discrimination is not easy. France has already implemented many measures (OECD, 2008b). The most cost-effective approach throughout the OECD is probably mentoring, in which volunteers who have extensive knowledge of the worlds of business or administration help youths from immigrant families forge links with business (OECD, 2008b). However, there is also merit in directly tackling overt discrimination. Finally, from a pool of equally qualified candidates, government bureaucracies could preferentially select the children of immigrants who are French citizens, since they are largely underrepresented in the civil service (OECD, 2009).

\section{Better co-ordination of support for youth}

In France, the main function of "local missions" is to promote the professional and social integration of youths. They are now an integral part of the public employment service (PES), Pôle emploi, but multiple players are involved in their funding, with contributions from the central government $(40 \%)$ and sub-national levels of government $(46 \%$ - from the regions for training, from departments for social action and from municipalities and their agglomerations for the maisons de l'emploi), from the European Union (7\%) and from other sources (7\%, including the PES). A priori, having an institution dedicated to youths' school-to-work transition is an asset. However, many co-ordination failures undermine the consistency and efficiency of the effort.

More than 80 employment policy measures have been implemented since 1977 (Sylla, 2008). The Cour des comptes $(2012 \mathrm{~b})$ relates the story of a delegation from the prefect who identified at least 21 job-search schemes in a municipality in the Rhône-Alpes region. With so many actors involved, ${ }^{19}$ navigating the school-to-work transition is a labyrinthine task that lacks transparency for both youths and companies (OECD, 2009). Issues of co-ordination are generally attributable to the absence of a consistent transition policy for youths.

These disparate stakeholders are poorly co-ordinated within jurisdictions that sometimes overlap and may be governed by different sub-national levels of government. They encounter difficulties exchanging data (often because of incompatible computer systems, but sometimes because of privacy concerns), such as between adjacent local missions in different departments, and sometimes they even compete with one another. With regard to local missions, for example, the obstacle to data transmission is above all a legal one, since each local mission is a distinct entity - hence the advantage of consolidating them into a single structure. A key point is that spheres of competency and co-contracting procedures between Pôle emploi

19. The Institut Montaigne (2012) provides a partial list of government bodies active in the "youth field", in isolation or sometimes even in competition with each other, and which could cooperate much more closely: lower and upper secondary schools, Missions générales d'insertion, local missions, Maisons de l'emploi, social services, second-chance schools, Pôle emploi, AFPA, social partners, local representatives from various territorial levels, CFAs. 
and local missions are vague. Similarly, CFAs are often poorly connected to the "network" of local missions, which is characterised by inconsistent administration in its 468 establishments.

These co-ordination failures create efficiency losses that are probably considerable. The Cour des comptes and the Ministry of the Economy and Finance have, moreover, identified shortcomings in the budgeting and accounting practices of the local missions. Measuring their performance is impossible owing to the complexity of their financing arrangements and their failure to adopt budgeting standards that are consistent with the LOLF (Cour des comptes, 2007). While the regions play an increasingly important role in apprenticeships, local missions are governed by officials elected locally. Shifting their governance up to the regional level (while retaining their involvement in local labour markets), whose role in labour-market integration should be strengthened, would yield economies of scale and better co-ordination. Since 2008, the funding has been overhauled in compliance with the budgetary requirements stemming from the LOLF through multi-year objective-setting agreements.

\section{Intervening at the time of dropping out}

Integrating youths who leave the school system without completing their programmes is a difficult task that most OECD member countries have to address; countries in Northern Europe, Luxembourg, Switzerland, Slovenia, Austria and Australia fare quite well in this respect (see Figure 1). Intervening after the student has left school is very costly, and the results are often disappointing, so it is important to wage this battle earlier to prevent dropping out (see above). While there is no panacea, an analysis of policies implemented in this area in recent decades (Quintini et al., 2007) reveals those courses of action yielding the best cost-benefit ratio, which should be the focus of government efforts.

The challenge is to pre-empt loss of contact with the world of work after leaving school, and the key is to detect signs of loss of labour-market attachment and to intervene rapidly, because course corrections become complicated when the youth is socially marginalised (Quintini et al., 2007). The best cost-efficiency ratios are obtained by targeting support to job-search strategies that are based on a reciprocal respect for obligations. Training, which is generally less effective in the case of dropouts, must be tailored and calibrated to labour-market needs as much as possible. In that vein, social-partner involvement may prove beneficial (Quintini et al., 2007). Many countries - notably Australia, Denmark and the United Kingdom - have set up programmes that allow them to intervene at an early stage of unemployment. For example, in Denmark, a pioneer in youth activation strategies since the mid-1990s, some of the resources provided are conditional on youths' active participation in these measures (OECD, 2009). Expansion of the RSA, as is recommended herein, may be conducive to the creation of activation strategies. In general, the PES must be resolutely oriented toward an approach based on activation and respect for reciprocal obligations (see OECD, 2013), for which Australia provides a good example (OECD, 2009).

Co-ordination between the PES and the Ministry of Education's General Integration Mission (MGI) is central to rapid intervention with youths who are in danger of losing their bearings. However, the interface between the educational system and the PES is defective, in particular with regard to the exchange of information and establishing contact as soon as the student leaves school (CERC, 2008): the MGI appears ineffectual, engaging with barely half of those who leave school without a diploma, while approximately half the youths who are in contact with local missions made their first contact more than one year after leaving the school system, and one in five more than three years later (Bonnevialle, 2008a and 2008b). The Netherlands, Norway and the United Kingdom have recently bolstered the co-ordination between the PES and educational authorities in order to more quickly identify and offer a solution to youths quitting school prematurely (OECD, 2011a). 
Monitoring and support platforms for dropouts have been progressively implemented since 2011 . They are primarily designed to provide a personalised and rapid response to all youths over 16 with no diploma or strategy, and to offer them a second chance. These platforms benefit from a unique information system that allows educational establishments, CFAs, local missions and sub-national levels of government to better identify problem cases - they are likely to significantly improve co-ordination among different players. One example of sound practice may also be found in the Commission on youth unemployment in the Netherlands, which, between 2004 and 2007, brought together representatives of business groups, unions and the educational sector and gave rise to initiatives that allowed co-ordination between the various stakeholders to be improved and youths in the process of dropping out to be flagged (OECD, 2008a).

\section{Second-chance schools appear to yield promising results, which should be assessed}

The main mechanisms for supporting youths include the "social integration contract" (contrat d'insertion dans la vie sociale, or CIVIS) and "second chance" training provided to youths with serious transition difficulties. CIVIS, created in 2005, are intended for youths with an education level lower than a secondary school diploma plus two years. The autonomy contract that ended in 2012 had been created in 2008 along with the dynamique Espoir Banlieues to facilitate access to employment for the 60000 youths living in disadvantaged neighbourhoods (approximately one third of NEETs aged 15 to 24 living in a ZUS).

Two second-chance provisions are targeted at young dropouts under 26 and having no diploma or professional qualifications: second-chance schools (E2C) and Défense deuxième chance (for Établissement public d'insertion de la défense dit Défense deuxième chance, Epide). They offer a fresh start by providing basic skills in the three Rs, and support youths as they lay out their own personal and professional paths. The former emphasises developing autonomy and self-confidence, and provides for a personalised trajectory in small groups and combining work and training; the second targets young people on their way to marginalisation, allowing them to receive behavioural, general and occupational training in highly disciplined residential centres - provisions that are analogous to the US Job Corps, an expensive programme but with a high social payoff (OECD, 2009).

Springing from a European initiative adopted in 1995 and based on a pedagogical paradigm that differs from classical educational models, E2C are created on the initiative of sub-national levels of government and those who work on the school-to-work transition issue. Business involvement in these programmes ensures account is taken of the local labour market. The proliferation of E2C was a cornerstone of the government's 2009 emergency plan to combat youth unemployment. In 2012, the network had over one hundred establishments in nearly half of all departments (versus one-quarter in 2008) and serviced approximately 12000 interns. The average cost of a youth's involvement with an E2C, the mean duration of which is seven months, is approximately EUR 6000 . While E2Cs do obtain promising results in terms of the school-to-work transition, the actual efficiency of this arrangement has never been assessed, limiting its further expansion (Cahuc et al., 2011). An evaluation is underway at the Ministry of Labour and will be published in 2013. The Epide comprise 20 establishments and provide 2300 places for youths who live in dormitories and receive behavioural, general and vocational training (business internships). Their annual budget is EUR 84 million, or approximately EUR 39000 per participant.

In 2012, EUR 419 million was allocated to delivering such support (CIVIS allocation, Fonds pour l'insertion professionnelle des jeunes, E2C, Epide and autonomy contracts). As a percentage of GDP $(0.02 \%)$, this is equivalent to approximately one-sixth of mean annual government expenditures over the past forty years on subsidised contracts other than apprenticeships, the efficiency of which is very low indicating a poor allocation of resources. 


\section{Territorialisation of the issues affecting youths}

\section{The spatial concentration of difficulties}

The challenges facing French youth have a marked territorial aspect. Approximately $7 \%$ of the population of France lives in one of 751 ZUS, which are "characterised by the presence of large clusters or neighbourhoods that are degraded and by a pronounced disequilibrium between housing and employment" (ONZUS, 2011). ZUS residents are younger on average than those in neighbouring areas: nearly one in three is less than 20, versus one in four in their agglomerations and the overall population (ONZUS, 2011). However, these territories concentrate socio-economic difficulties: the mean standard of living is lower than in their agglomerations (by approximately $45 \%$ ), the poverty rate is $2.5-3$ times higher, the population is less educated, unemployment twice as pervasive, housing of poorer quality, insecurity more prevalent, etc. (ONZUS, 2011). Poverty is particularly common among youths from these neighbourhoods, with an unemployment rate of 15-24 year-olds over $40 \%$. Overall, approximately one NEET in seven between the ages of 15 and 24 lives in a ZUS. These conditions of extremely precarious subsistence have festered for several decades.

The spatial mechanisms of exclusion in these French banlieues may result from the negative impact of social segregation (acquisition of human capital, networks allowing access to jobs, stigmatisation of the neighbourhoods and discrimination by some employers), ghettoisation (spatial mismatch) (Gobillon and Selod, 2007), which increases frictional unemployment, and lack of support from employment services. Several lessons can be learnt from the analysis that has been conducted of this issue:

- in addition to individual characteristics neighbourhood effects appear to contribute to educational failure (Goux and Maurin, 2007);

- education level and family background remain the most important factors determining access to jobs and the wage level;

- if observed individual characteristics are carefully accounted for, the fact of living in a ZUS is negatively correlated with the likelihood of finding a job (Aeberhardt et al., 2010a and 2010b; Couppié and Gasquet, 2011);

- conditional on having a job, the fact of living in a ZUS affects neither the nature of the job nor earnings (Couppié et al., 2010): once employed, neighbourhood externalities and discrimination practically vanish;

- $\quad$ since the choice of where to live is endogenous, location variables in econometric estimations in fact reflect unobserved attributes and the effect generally observed is not causal; "residential environment matters most to an individual's mental health and exposure to crime" (Oreopoulos, 2008, for a summary);

- experiments indicate that a random relocation of individuals outside of a segregated residential environment does not affect their outcomes with respect to education level, employment or earnings (Oreopoulos, 2008); and

- experiments that involved subsidising activities in some ZUS in France (416 urban renewal zones and 100 urban tax-free zones) were inconclusive: poor targeting of the local population, massive deadweight losses, weak overall impact (OECD, 2008a). 
More research to corroborate the analysis and inform policy choices is needed in this area. However, some lessons can be gleaned from these results. Priority should be given to bolstering the educational system in these territories (see supra) and supporting young jobseekers while ensuring that the quality of housing and transportation does not hamper access to work.

\section{Piecemeal zoning policy}

The inter-ministerial urban policy implemented since the 1980s has been designed to break the dynamic of urban decay that pervades some areas. General issues regarding urban policy and its effectiveness fall well outside of the scope of this analysis. One finding is, however, indisputable: the difficulties in these neighbourhoods have not abated. It has not been demonstrated that targeting social policy on zones rather than directly at individuals is effective (OECD, 2007c). The means deployed in these target areas often run up against thorny co-ordination problems that sap their effectiveness and create a climate of stigmatisation. Indeed, the population living in ZUS has been falling by approximately $0.5 \%$ annually since 1990, with the poorest tending to remain (OECD, 2007c), exacerbating the existing problems.

Urban policy is based on a priority geography built around zones that are juxtaposed in an inconsistent fashion and dilute government intervention (OECD, 2007c). As is often the case in France, responsibilities are scattered across numerous jurisdictions, and inter-communal co-operation is minimal (Cour des comptes, 2012b). Since 2006, urban policy has designated 2493 priority neighbourhoods (Contrats urbains de cohésion sociale, or CUCS) covering approximately $12 \%$ of the population of France (approximately 7.7 million inhabitants); 1752 are not in a ZUS. Conversely, of the 751 ZUS (4.4 million inhabitants), ten do not fall within a CUCS neighbourhood. The National Urban Regeneration Agency (Agence nationale pour la rénovation urbaine, or ANRU), which receives a large share of the urban policy credits, covers a total of 542 neighbourhoods, of which 112 are non-ZUS. As to priority education, $40 \%$ of ECLAIR and $75 \%$ of RRS lie outside of ZUS. Also, approximately $40 \%$ of lower-secondary schools located within ZUS are not classified as priority education. Priority geography was to be overhauled in 2010, but the reform has been delayed until 2014. It should be done as soon as possible. In addition, it is questionable whether strict neighbourhood-by-neighbourhood zoning should be maintained, or resources allocated on the basis of precise criteria (unemployment rate, the proportion of youths without professional qualifications, the proportion of social assistance recipients, etc.), while granting more authority to prefects and local representatives (cf. Hamel and André, 2009).

\section{No affirmative action in support of employment in problem neighbourhoods}

As to the matter of support for employment in struggling neighbourhoods, the previously identified co-ordination issues crop up with the same urgency. Before the introduction of "jobs for the future", the principal measure targeted on the ZUS was the creation of autonomy contracts launched in 2008 (see above) with the dynamique Espoir banlieues. Aside from this action, data incompatibility issues make it difficult to estimate to what extent employment policy targets priority neighbourhoods. According to IGAS (2010) and Cour des comptes (2012b), the means are inadequate to the task. Plus, Pôle emploi is encountering difficulties assigning staff to these places, resulting in an inadequate monitoring of jobseekers. OECD (2008b) observed that youths in the ZUS have a hard time accessing the PES. Approximately $17 \%$ of employment policy credits and $10 \%$ of subsidised contracts go to the ZUS (Cour des comptes, 2012b). Inasmuch as approximately 14\% of the unemployed and 14\% of NEET aged 15-24 live in ZUS, this does not suggest that there is underinvestment in ZUS by employment policies, but there does not appear to be any affirmative action in this area either. 


\section{Box 1. Recommendations to improve the economic situation of young people}

\section{Concentrate educational resources on primary schooling and students from disadvantaged backgrounds}

- $\quad$ Transfer funding from secondary to primary schooling in a budget-neutral manner. Achieve economies of scale by speeding up the merger of small schools.

- $\quad$ Use the surplus public financing allocated to education to make priority education a genuine priority. Use these resources to develop the specific skills needed to develop priority education networks and attract experienced teachers. Give these schools greater autonomy in terms of recruitment and tailored support to individual students, and develop parental involvement in these schools.

- $\quad$ Allow primary schools and their principals at least as much authority as at secondary-school level by changing their status into public teaching establishments and by giving their principals clear-cut line responsibilities.

- Improve teacher training by placing the emphasis on teaching practices and by making greater use of programmes alternating academic training and vocational experience. Rationalise non-wage costs in order to be able to increase teachers' pay.

- Drastically and swiftly reduce the use of year repetition, and introduce teaching practices that are better tailored to individual students in order to reduce dropout rates.

- Reform the functions and inspect more closely the activity of career guidance counsellors/psychologists. Draw a clear distinction between, and give priority to, their specific guidance functions to be developed by forging closer links with firms. Increase the involvement of teachers in pupils' career guidance through tailored instruction. Introduce an initial foundation course year in upper-secondary technology and professional studies. Provide, through the public careers guidance service, detailed information on job opportunities resulting from the courses offered by higher education establishments.

Improve the equity and efficiency of higher education

- Reduce the segmentation of higher education by shifting the public financing of higher education institutions in favour of universities in a budget-neutral way. Develop courses at degree level that are valued in the labour market.

- $\quad$ Give universities greater autonomy in terms of financial management, human resources and curriculum (including student selection). Make part of funding awards contingent on mergers between establishments and on strengthening the effective role of research and higher education centres (PRES). Increase tuition fees and introduce student loans with repayment conditional on future earnings.

\section{Develop the independence of young people, and increase youth employment}

- Facilitate access for young people to social housing by increasing the supply of small dwellings and better targeting. Develop student accommodation.

- Extend the RSA to young adults who have completed their studies according to an age-dependent progressive scale, strictly conditional on implementing an effective activation strategy comprising participation in a training programme or active job search. At the same time bring down all age limits to 18 years of age in all legislation. In particular, abolish the inclusion of adult children in the household for tax assessment purposes, as well as the family benefits to which they provide entitlement, and if necessary increase means-tested grants for students. Use the same (relative) scale as for the RSA to fix the minimum age according to age.

- $\quad$ Reduce the minimum wage relative to the average wage and reduce the use of labour-market dualism (Assessment and Recommendations, Box 5).

- $\quad$ Continue to focus subsidised contracts on combined work-study programmes, grants for which should be redirected towards the low-skilled. Improve the co-ordination of, or even close the gap between, school-based vocational training and apprenticeship. Assess the performance of apprentice training centres. Severely restrict the use of subsidised contracts for non-combined work-study programmes to emergency countercyclical policy. 
- Improve the co-ordination of the many actors involved in securing entry into employment, in particular to take charge of young dropouts at an early stage by concentrating resources on activation strategies (which will be facilitated by the introduction of a genuine RSA for young people). Rationalise the support to help youths find employment by limiting the number of schemes, by shifting the oversight of local initiatives to the regional level and by creating regional structures that include the various actors concerned (local missions, general social integration mission run by the Ministry of Education, information and guidance centres, etc.).

- Consider extending the second-chance schools, depending on the results of the government's ongoing evaluation of the scheme.

\section{Rationalise zoning policies}

- $\quad$ Rethink the positive discrimination based on geographical criteria by making municipal zoning policy more transparent and by ensuring its consistency with priority education. A more radical reform aimed at avoiding the stigma from zoning might replace policies aimed directly at given territories by resource allocation based on the characteristics of the individuals composing the target population (education, housing, transport, support for entry into employment, etc.).

\section{Bibliography}

Abriac, D., R. Rathelot and R. Sanchez (2009), "L'apprentissage, entre formation et insertion professionnelles", Formations et Emploi, INSEE.

Aeberhardt, R., D. Fougère, J. Pouget and R. Rathelot (2010a), "L'emploi et les salaires des enfants d'immigrés", Economie et Statistique, No. 433-434, 31-46.

Aeberhardt, R., E. Coudin and R. Rathelot (2010b), “Les écarts de taux d'emploi selon l'origine des parents : comment varient-ils avec l'âge et le diploma”, France, portrait social, INSEE.

Aeberhardt, R., L. Crusson and P. Pommier (2011), “Les politiques d'accès à l'emploi en faveur des jeunes : qualifier et accompagner", France, Portrait social INSEE.

Aghion, P. (2011), “L'excellence universitaire et l'insertion professionnelle", Rapport au ministre de l'enseignement supérieur Valérie Pécresse.

Allègre, G., M. Cochard and M. Plane (2012), "Quels effets du "contrat de génération" sur l'emploi et les finances publiques", Evaluation du projet économique du quinquennat 2012-2017, Notes de l'OFCE, No. 23/26, July.

Augustine, C., G. Gonzalez, G.S. Ikemoto, J. Russell, G. Zellman, L. Constant, J. Armstrong and J. Dembosky (2009), Improving School Leadership: The Promise of Cohesive Leadership Systems. Santa Monica, Calif.: RAND Corporation.

Avvisati, F., M. Gurgand, N. Guyon and E. Maurin (2010), "Quels effets attendre d'une politique d'implication des parents d'élèves dans les collèges ? Les enseignements d'une expérimentation contrôlée", Rapport pour le Haut Commissaire à la Jeunesse. 
Bassanini, A. and R. Duval (2006), "Employment Patterns in OECD Countries: Reassessing the Role of Policies and Institutions", OECD Social, Employment and Migration Working Papers, No. 4.

Batard, P.-E. and E. Saillard (2011), "Le chômage des jeunes : quel diagnostic ?”, Lettre Trésor-Eco, No. 92.

Bénabou, R., F. Kramarz and C. Prost (2009), “The French zones d'éducation prioritaire: Much ado about nothing?", Economics of Education Review, 28, 345-356.

Bonnevialle, L. (2008a), “L'activité des missions locales et PAIO en 2006”, DARES, Premières Synthèses, No. 02.1.

Bonnevialle, L. (2008b), “L'accompagnement des jeunes peu qualifiés par les missions locales”, Les Travaux de l'Observatoire.

Boulhol, H. and P. Sicari (2013a), "Do the average level and dispersion of socio-economic background measures explain France's gap in PISA scores?", OECD Economics Department Working Papers, No. 1028.

Boulhol, H. and P. Sicari (2013b), "Labour market performance by age groups: a focus on France", OECD Economics Department Working Papers, No. 1027.

Cédiey, E. and F. Foroni (2007), Les discriminations à raison de "l'origine" dans les embauches en France. Une enquête nationale par tests de discrimination selon la méthode du Bureau International du Travail, International Labour Organisation, Geneva.

Cédiey, E. and F. Foroni (2008), “Discriminations à l'embauche fondées sur l'origine à l'encontre de jeunes français(es) peu qualifié(e)s", DARES, Premières Synthèses, No. 06.3.

Cahuc, P. and A. Zylberberg (2009), Les réformes ratées du Président Sarkozy, Flammarion.

Cahuc, P., S. Carcillo, O. Galland and A. Zylberberg ((2011), La Machine à trier, Edition Eyrolles.

Caille, J.-P. (2001), "Scolarisation à 2 ans et réussite de la carrière scolaire au début de l'école maternelle", Education \& formations, No. 60.

CERC (2008), Un devoir national. L'insertion des jeunes, Rapport No. 9.

Claus, P. and O. Roze (2009), "Troisième note de synthèse sur la mise en œuvre de la réforme de l'enseignement primaire", Note à Monsieur le Ministre de l'Education nationale, July.

Clergeau, M.-F. (2009), Rapport fait au nom de la Commission des affaires sociales sur le Projet de loi de financement de la Sécurité sociale pour 2010 (no 1976), Tome IV, Famille, Assemblée nationale.

Commission sur la politique de la jeunesse (2009), Livre vert, July.

Cordelier, C. (2006), “De 1977 à 2002, l'emploi des jeunes salariés est de plus en plus découpé par des interruptions", INSEE Première, No. 1104.

CESE (2011), 40 ans de formation professionnelle : bilan et perspectives, Avis du Conseil économique social et environnemental, December. 
Couppié, T., J.-F. Giret and S. Moullet (2010), "Lieu de résidence et discrimination salariale : le cas des jeunes habitant dans une zone urbaine sensible", Economie et Statistique, 433-434, 47-70/

Couppié, T. and C. Gasquet (2011), "Les jeunes des ZUS inégalement pénalisés au moment de l'insertion", Céreq, Net.Doc.79.

Cour des comptes (2007), Rapport public annuel, February.

Cour des comptes (2008), "La formation professionnelle tout au long de la vie", Rapport public thématique.

Cour des comptes (2010), “L'Education nationale face à l'objectif de la réussite de tous les élèves", Rapport public annuel, February.

Cour des comptes (2011), "Les pôles de recherche et d'enseignement supérieur (PRES) : un second souffle nécessaire", Rapport public annuel, February.

Cour des comptes (2012a), "La réussite en licence : le plan du ministère et l'action des universités", Rapport public annuel, February.

Cour des comptes (2012b), "La politique de la ville, une décennie de réformes", Rapport public thématique, July.

DARES (2011), “Emploi des jeunes”, Document d'études, No. 166, November.

DARES (2012), “L'ajustement du marché du travail français pendant la crise de 2008-2009”, Dares Analyse, No. 040, January.

Daussin, J.-M., S. Keskpaik and T. Rocher (2011), "L'évolution du nombre d'élèves en difficulté face à l'écrit depuis une dizaine d'années", France, portrait social, INSEE.

EAO (2009), Chiffres clés de l'éducation en Europe 2009, Agence Exécutive "Education, audiovisuel et culture", European Commission.

Égert, B. (2013), "Efficiency and Equity of the tax and transfer system", OECD Economics Department Working Papers, No. 1038.

Estermann, T., T. Nokkala and M. Steinel (2011), University Autonomy in Europe II - The Scorecard, European University Association, Brussels.

Floc’h, B. (2012), “Les plans se succèdent, mais la pénurie de logements étudiants perdurent”, Le Monde, 28 August.

Fougère, D., F. Kramarz and T. Magnac (2000), "Youth employment policies in France", European Economic Review, 44, 928-942.

Fougère, D., F. Kramarz and J. Pouget (2011), "Youth unemployment and crime in France", Journal of the European Economic Association, 7, No. 5, 909-938.

Gaini, M., A. Leduc and A. Vicard (2012), "A scarred generation? French evidence on young people entering into a tough labour market", Documents de travail de l'INSEE, No. G2012-05. 
Galland, O. (2009), Les jeunes français ont-ils raison d'avoir peur?, Armand Colin.

Gobillon, L. and H. Selod (2007), "Les déterminants locaux du chômage en région parisienne", Economie et Prévision, No. 180-181, 19-38.

Goux, D. and E. Maurin (2007), "Close Neighbours Matter: Neighbourhood Effects on Early Performance at School”, Economic Journal, 117, No. 523, 1193-1215.

Gruber, J., K. Milligan and D.A. Wise (2009), "Social Security Programs and Retirement Around the World: The Relationship to Youth Employment, Introduction and Summary", NBER Working Papers, No. 14647.

Hamel, G. and P. André (2009), "Une conception rénovée de la politique de la ville : d'une logique de zonage à une logique de contractualisation”, Rapport parlementaire, September.

HCE (2008), L'orientation scolaire, Bilan des résultats de l’École.

HCF (2010), "L'investissement de la nation en direction des familles", Note, September.

Heckman, J.J. (2008), “Schools, Skills, and Synapses”, NBER Working Papers, No. 14064.

Heckman, J.J. and P. Carneiro (2003), "Human Capital Policy", in Inequality in America: What Role for Human Capital Policy?, J. Heckman and A. Krueger (eds.), MIT Press, Cambridge, Mass.

IGAS (2010), L'accès à l'emploi des jeunes des quartiers prioritaires de la politique de la ville, Rapport, July.

Institut Montaigne (2004), Les oubliés de l'égalité des chances, Rapport, January.

Institut Montaigne (2010), Vaincre l'échec à l'école publique, Rapport, April.

Institut Montaigne (2012), Choisir les bons leviers pour insérer les jeunes non qualifiés, Note, June.

Le Rhun, B. and C. Minni (2012), "Evolution récente de l'insertion des jeunes sur le marché du travail selon le niveau de diplôme", DARES Analyses, No. 013.

Martin, J.P. and D. Grubb (2001), "What works and for whom: a review of OECD countries' experiences with active labour market policies", IFAU-Office of Labour Market Policy Evaluation, Working Paper, No. 14.

Mauger, G. (2007), L'émeute de novembre 2005, Éditions du croquant.

Maurin, E. (2004), Le ghetto français, Edition La République des idées, Seuil.

Maurin, E. (2007), La nouvelle question scolaire, Seuil.

MEN (2010), "L'évolution des compétences générales des élèves en fin de collège de 2003 à 2009", Note d'information, 10.22 .

Merle, P. (2011), La ségrégation scolaire, Collection Repères, La Découverte. 
ECO/WKP(2013)33

Moisan, C. (2011), "Comment en finir avec l'échec scolaire : les mesures efficaces, Projet de rapport national de base de la France.

Obin, J-P. (2007), “Améliorer la direction des établissements scolaires", Rapport de base national de la France présenté dans le cadre de l'activité de l'OCDE.

OECD (2005), Teachers Matter, OECD Publishing.

OECD (2007a), Starting Strong II: Early Childhood Education and Care, Chapter 5, OECD Publishing.

OECD (2007b), Overcoming Failure at School, OECD Publishing.

OECD (2007c), OECD Economic Surveys: France, OECD Publishing.

OECD (2008a), Jobs for Youth: United Kingdom, OECD Publishing.

OECD (2008b), Jobs for immigrants, Volume 2, Chapter 3, OECD Publishing.

OECD (2009), Jobs for Youth: France, OECD Publishing.

OECD (2010), Equal Opportunities? The labour market performance of children of immigrants, OECD Publishing.

OECD (2011a), Off to a Good Start? Jobs for Youth, OECD Publishing.

OECD (2011b), OECD Economic Surveys: France, OECD Publishing.

OECD (2012a), "Under shock: How to spread macroeconomic risks more fairly", Going for Growth, OECD Publishing.

OECD (2012b), Equity and quality in education, OECD Publishing.

OECD (2012c), France: Promouvoir la croissance et la cohésion sociale, Série "Politiques meilleures", OECD Publishing.

OECD (2012d), Education at a glance, OECD Publishing.

OECD (2013), OECD Economic Surveys: France, OECD Publishing.

ONZUS (2011), Rapport 2011.

OPH (2011), Les offices en 2009, données sociales, April.

Oreopoulos, P. (2008), "Neighbourhood Effects in Canada: A Critique", Canadian Public Policy, XXXIV, No. 2, 237-258.

Pisu, M. (2012), "Less Income Inequality and More Growth - Are they Compatible? Part 5. Poverty in OECD countries", OECD Economics Department Working Papers, No. 928.

Quintini, G. and S. Martin (2006), "Starting Well or Losing their Way? The Position of Youth in the Labour Market in OECD Countries", OECD Social, Employment and Migration Working Papers, No. 8. 
Quintini, G., J.P. Martin and S. Martin (2007), “The Changing Nature of the School-to-Work Transition Process in OECD Countries", IZA Discussion Paper, No. 2582.

Rivkin, S.G., E.A. Hanushek and J.F. Kain (2005), "Teachers, Schools, and Academic Achievement", Econometrica, 73, Vol. 2.

Sanchez, R. (2011), “L'apprentissage en 2010", DARES Analyses, No. 089.

Sanchez, R. (2012), "Le contrat de professionnalisation en 2011", DARES Analyses, No. 021.

Scarpetta, S., A. Sonnet and T. Manfredi (2010), "Montée du chômage des jeunes dans la crise : comment éviter un impact négatif à long terme sur toute une génération?", Documents de travail de l'OCDE: Questions sociales, emploi et migrations, No. 106.

Sylla, F. (2008), L'emploi des jeunes des quartiers populaires, Avis du Conseil économique et social. 
ECO/WKP(2013)33

\section{WORKING PAPERS}

The full series of Economics Department Working Papers can be consulted at www.oecd.org/eco/workingpapers/

1040. Improving employment prospects for young workers in Spain

(April 2013) by Anita Wölfl

1039. Youth labour market performance in Spain and its determinants - a micro-level perspective (April 2013) by Juan J. Dolado, Marcel Jansen, Florentino Felgueroso, Andrés Fuentes and Anita Wölfl

1038. The efficiency and equity of the tax and transfer system in France (April 2013) by Balázs Égert

Efficacité et équité du système de prélèvements et de transferts en France (avril 2013) par Balázs Égert

1037. Income inequality and poverty in Colombia. Part 2. The redistributive impact of taxes and transfers

(April 2013) by Isabelle Joumard and Juliana Londoño Vélez

1036. Income inequality and poverty in Colombia. Part 1. The role of the labour market (April 2013) by Isabelle Joumard and Juliana Londoño Vélez

1035. Policy options to durably resolve euro area imbalances

(March 2013) by Yvan Guillemette and Dave Turner

1034. Labour market, welfare reform and inequality in the United Kingdom

(March 2013) by Christophe André, Clara Garcia, Giulia Giupponi and Jon Kristian Pareliussen

1033. Work incentives and Universal Credit-reform of the benefit system in the United Kingdom (March 2013) by Jon Kristian Pareliussen

1032. Strengthening social cohesion in Luxembourg: making efficiency and equity go hand in hand (March 2013) by Jean-Marc Fournier and Clara Garcia

1031. The price of oil - Will it start rising again?

(March 2013) by Jean-Marc Fournier, Isabell Koske, Isabelle Wanner and Vera Zipperer

1030. The system of revenue sharing and fiscal transfers in China

(February 2013) by Xiao Wang and Richard Herd

1029. The declining competitiveness of French firms reflects a generalised supply-side problem (February 2013) by Hervé Boulhol and Patrizio Sicari

1028. Do the overall level and dispersion of socio-economic background measures explain France's gap in PISA scores?

(February 2013 by Hervé Boulhol and Patrizio Sicari

1027. Labour market performance by age groups: a focus on France

(February 2013) by Hervé Boulhol and Patrizio Sicari 
1026. Moving towards a single labour contract: pros, cons and mixed feelings

(February 2013) by Nicolas Lepage-Saucier, Juliette Schleich and Etienne Wasmer

1025. Boosting productivity in Australia

(January 2013) by Vassiliki Koutsogeorgopoulou and Omar Barbiero

1024. Housing, financial and capital taxation policies to ensure robust growth in Sweden (January 2013) by Müge Adalet McGowan

1023. Labour market and social policies to foster more inclusive growth in Sweden (January 2013) by Stéphanie Jamet, Thomas Chalaux and Vincent Koen

1022. Educational attainment and labour market outcomes in South Africa, 1994-2010 (January 2013) by Nicola Branson and Murray Leibbrandt

1021. Education quality and labour market outcomes in South Africa

(January 2013) by Nicola Branson and Murray Leibbrandt

1020. Do policies that reduce unemployment raise its volatility? Evidence from OECD countries (January 2013) by Alain de Serres and Fabrice Murtin

1019. Slovakia: A catching up euro area member in and out of the crisis (January 2013) by Jarko Fidrmuc, Caroline Klein, Robert Price and Andreas Wörgötter

1018. Improving the fiscal framework to enhance growth in an era of fiscal consolidation in Slovakia (January 2013) by Caroline Klein, Robert Price and Andreas Wörgötter

1017. Investing efficiently in education and active labour market policies in Slovakia (January 2013) by Caroline Klein

1016. The performance of road transport infrastructure and its links to policies (January 2013) by Henrik Braconier, Mauro Pisu and Debra Bloch

1015. The US labour market recovery following the great recession (January 2013) by Wendy Dunn

1014. Why do Russian firms use fixed-term and agency work contracts? (December 2012) by Larisa Smirnykh and Andreas Wörgötter

1013. The Equity implications of fiscal consolidation (December 2012) by Lukasz Rawdanowicz, Eckhard Wurzel and Ane Kathrine Christensen

1012. The Dutch labour market: preparing for the future (December 2012) by Mathijs Gerritsen and Jens Høj

1011. Reforming policies for the business sector to harvest the benefits of globalisation in the Netherlands

(December 2012) by Mathijs Gerritsen and Jens Høj 